\title{
Thailand: Financial System Stability Assessment
}

This Financial System Stability Assessment on Thailand was prepared by a staff team of the International Monetary Fund as background documentation for the periodic consultation with the member country. It is based on the information available at the time it was completed on April 29, 2008. The views expressed in this document are those of the staff team and do not necessarily reflect the views of the government of Thailand or the Executive Board of the IMF.

The policy of publication of staff reports and other documents by the IMF allows for the deletion of market-sensitive information.

Copies of this report are available to the public from

International Monetary Fund • Publication Services

700 19th Street, N.W. • Washington, D.C. 20431

Telephone: (202) 623-7430 • Telefax: (202) 623-7201

E-mail: publications@imf.org • Internet: http://www.imf.org

\section{International Monetary Fund Washington, D.C.}





\title{
INTERNATIONAL MONETARY FUND
}

\author{
THAILAND
}

\section{Financial System Stability Assessment}

\author{
Prepared by the Monetary and Capital Markets and Asia and Pacific Departments
}

\author{
Approved by Jaime Caruana and David Burton
}

April 29, 2008

This Financial System Stability Assessment (FSSA) is based on the work of the IMF/World Bank teams that visited Thailand as part of the Financial Sector Assessment Program (FSAP) in January/February and May/June, 2007. The findings were discussed with the authorities during the Article IV consultation mission that took place in March 2008. The key findings of the FSSA are:

- The soundness of Thailand's financial system has been strengthened since the financial crisis of the late 1990s. Substantial progress has been made in upgrading the regulatory and supervisory system and improving macroeconomic management. Banks are reporting solid profitability and improved solvency.

Private corporations, which are the banks' primary borrowers, have strengthened their balance sheets and reduced leverage.

- Notwithstanding these improvements, policymakers face several critical challenges to further enhance the stability and efficiency of the financial system.

$\Rightarrow$ From simulated stress-test scenarios, Thaiiland banks remain vulnerable to a significant slowdown in domestic economic growth, with liquidity risk found to be material for a few banks. These findings underscore the importance of continued close supervisory attention by the Bank of Thailand (BOT), in particular to weak banks in the system.

$\Rightarrow$ While Thailand's financial regulatory and supervisory structure generally exhibits a high level of compliance with international standards, measures are needed to strengthen the legal framework.

The effectiveness of the current framework governing banking and securities and the monetary framework would be improved by stronger laws and greater independence of the regulators and the monetary authority. Initiatives to strengthen the supervisory framework for insurance and banking need to be continued, including by moving toward the planned risk-based supervision framework. The Anti Money Laundering/Combating the Financing of Terrorism (AML/CFT) framework also needs to be brought in line with international standards. Quick passage of the draft legal reforms would address many of these shortcomings.

$\Rightarrow$ Ten years after the crisis, reducing the still high level of distressed assets and transitioning from a blanket guarantee to a more limited deposit insurance system should be priorities. The government should also continue to divest its equity holding in private commercial banks intervened during the crisis and should regulate and supervise government-owned deposit-taking specialized financial institutions (SFIs) in a manner similar to private commercial banks.

Mr. Fiechter and Ms. Gobat (MCM) are the main authors of this report. The word count is 7,189.

The FSAP team was headed by Jonathan Fiechter (IMF) and Tom Rose (World Bank), and was composed of Abdessatar Ouanès (Deputy Chief), Jeanne Gobat, Allison Holland, Elias Kazarian, Aditya Narain, Antonio Garcia Pascual and Ivan Tchakarov (all IMF); Larry Promisel (Deputy Chief), Nagavalli Annamalai, Loic Chiquier, David Scott, Craig Thorburn, and Lynn Yeargin (all World Bank); and Jonathan Katz (World Bank consultant) and Mr. Göran Lind (IMF consultant). In addition, an assessment of the AML/CFT standard was undertaken as part of the FSAP by a separate IMF-led team in February 2007. The team received excellent cooperation and support from the authorities.

FSAPs are designed to assess the stability of the financial system as a whole and not that of individual institutions. They have been developed to help countries identify and remedy weaknesses in their financial sector structure, thereby enhancing their resilience to macroeconomic shocks and cross-border contagion. FSAPs do not cover risks that are specific to individual institutions such as asset quality, operational or legal risks, or fraud. 
Glossary

Executive Summary.

I. Current Macroeconomic and Financial Environment 12

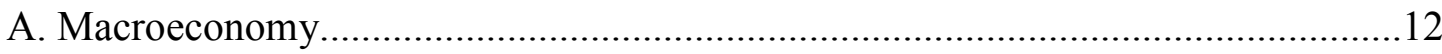

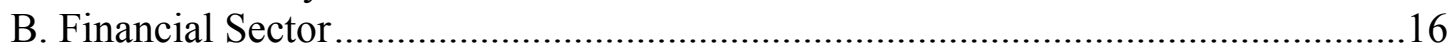

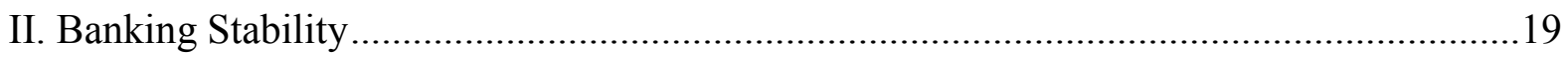

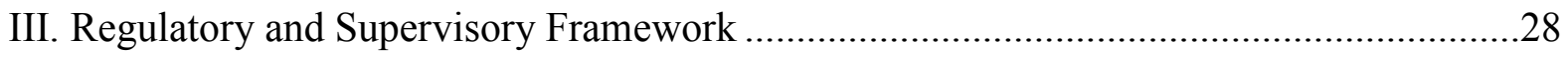

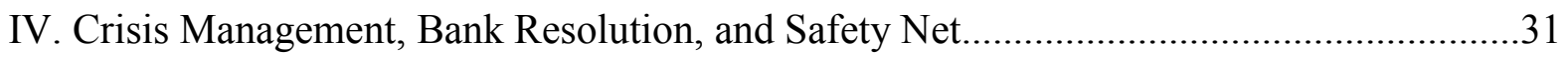

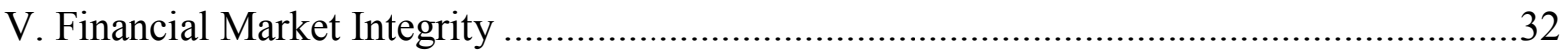

Tables

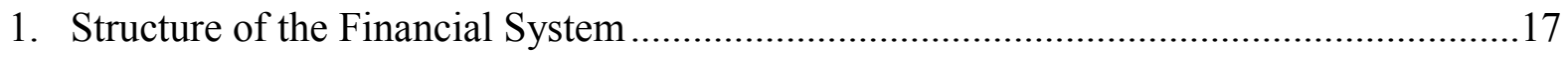

2. Developments in the Government's Equity Stake of Thai Banks ..................................18

3. Banks' Profitability and Solvency Indicators .............................................................. 19

4. 2007 Ratings of Six Largest Commercial Banks .........................................................22

5. Summary Compliance with the BCP-Report on the Observance of Standards and Codes

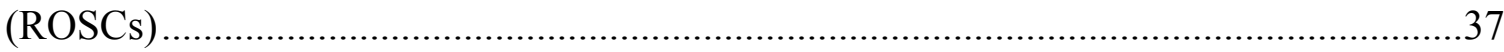

6. Recommended Action Plan to Improve Compliance with the Basel Core Principles .......39

7. SFI Revenue Remittance............................................................................................4 43

8. Summary Implementation of the IOSCO Principles-ROSCs ......................................45

9. Recommended Action Plan to Improve Implementation of the IOSCO Principles ..........48

10. Summary Observance of the Transparency Code (Monetary Policy) ...............................53

11. Recommended Action Plan to Improve Observance of the Transparency Code

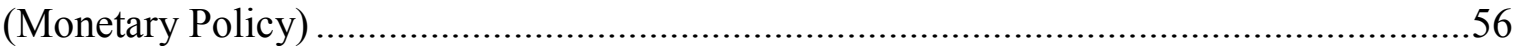

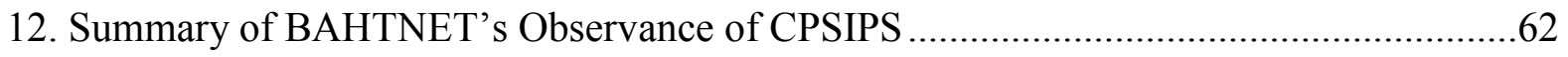

13. Recommended Actions to Improve BAHTNET's Observance of CPSIPS and the BOT Responsibilities in Applying the CPs .........................................................................64

14. Summary of Observance of the RSSS - ROSCs ........................................................69

15. Recommended Action Plan to Improve Observance of the RSSS ..................................72

16. Prioritized Key Recommendations to Improve the AML/CFT System..........................81

Figures

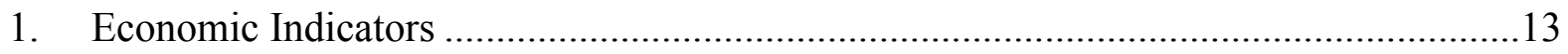

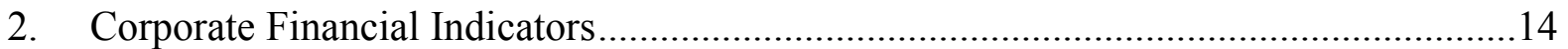

3. Household Financial Indicators ............................................................................ 15

4. Banking Sector Financial Soundness Indicators .........................................................20

5. Distressed Assets and Loan Loss Provisions ............................................................21 
6. Standard and Poor's Distribution of BFSR Ratings for Systemically

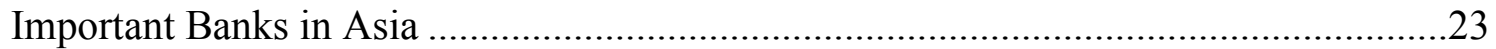

7. Regional Comparison of Structure of Financial Sector ...................................................98

Boxes

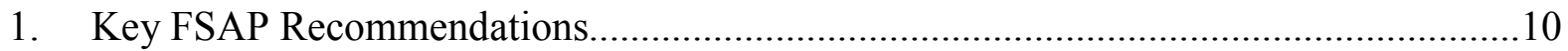

2. Recent Reforms to the Financial Sector Insitutional Framework ..................................11

3. 1997 Financial Crisis and Crisis Management Framework ……....................................8

Annex: Observance of Financial Sector Standards and

Codes-Summary Assessments

Appendices

I. Main Developments Since the 1997 Financial Crisis.

II. Stress Tests.

Appendices Tables

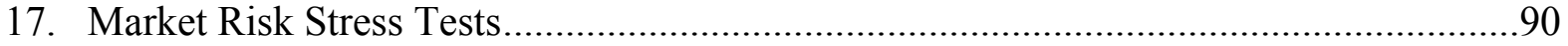

18. Stress Tests for Interest Rate Risk on the Banking Book ................................................

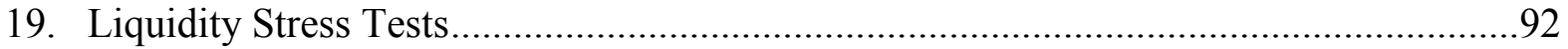

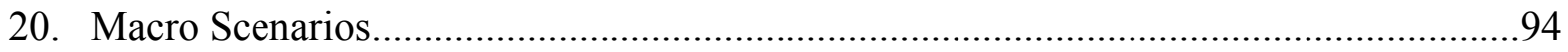

21. Summary of Macro Scenario Stress Tests …………......................................................95

Statistical Appendix Tables

22. Core and Encourage Set of Financial Soundness Indicators …......................................97

23. Regional Bond Market Indicators, end-2006 ................................................................99 


\section{GLOSSARY}

AMC

AML/CFT

AMLA

AMLB

AMLO

APG

ASEAN

BAHTNET

BCP

BFSR

BICRA

BOT

CAR

CCP

CDD

CDO

$\mathrm{CMC}$

CoD

CPSIPS

CPSS

CSD

DA

DAR

DNFBPs

DPA

DOI

DSI

DVP

ECS

FAP

FATF

FIBA

FIDF

FIPC

FIs

FIU

FPO

FRA

FSAP

FSSA

GDP
Asset Management Company

Anti-Money Laundering/ Combating the Financing of Terrorism

Anti-Money Laundering Act

Anti-Money Laundering Board

Anti-Money Laundering Office

Asia-Pacific Group

Association of South-East Asian Nations

Bank of Thailand Automated High-Value Transfer Network

Basel Core Principles for Effective Banking Supervision

Bank Financial Strength Rating

Banking Industry Country Risk Assessment

Bank of Thailand

Capital Adequacy Ratio

Central Counterparty

Customer Due Diligence

Collateralized Debt Obligations

Crisis Management Committee

Court of Directors

Core Principles for Systemically Important Payment Systems

Committee of Payment and Settlement Systems

Central Securities Depository

Detailed Assessment

Detailed Assessment Report

Designated Nonfinancial Businesses and Professions

Deposit Protection Agency

Department of Insurance

Department of Special Investigation

Delivery versus Payment

Electronic Checks Clearing System

Federation of Accounting Profession

Financial Action Task Force

Financial Institutions Business Act

Financial Institution Development Fund

Financial Institutions Policy Committee

Financial Institutions

Financial Intelligence Unit

Fiscal Policy Office

Financial Sector Restructuring Authority

Financial Sector Assessment Program

Financial System Stability Assessment

Gross Domestic Product 


\begin{tabular}{|c|c|}
\hline GHB & Government Housing Bank \\
\hline GSB & Government Savings Bank \\
\hline IAS & International Accounting Standards \\
\hline IMF & International Monetary Fund \\
\hline IOSCO & International Organization of Securities Commission \\
\hline IT & Information Targeting \\
\hline KTB & Krung Thailand Bank \\
\hline LEAs & Law Enforcement Agencies \\
\hline ML & Money Laundering \\
\hline MLAT & Mutual Legal Assistance Treaty \\
\hline MOF & Ministry of Finance \\
\hline MOU & Memorandum of Understanding \\
\hline MPC & Monetary Policy Committee \\
\hline NAV & Net Asset Value \\
\hline NPAs & Nonperforming Assets \\
\hline NPLs & Nonperforming Loans \\
\hline NPO & Nonprofit Organizations \\
\hline $\mathrm{OAG}$ & Office of the Auditor General \\
\hline ONCB & Office of the Narcotics Control Board \\
\hline OTC & Over-the-Counter \\
\hline PCA & Prompt Corrective Action \\
\hline PDs & Probability of Default \\
\hline PPA & Prompt Preventive Action \\
\hline PSC & Payment Systems Committee \\
\hline ROA & Return on Assets \\
\hline ROSC & Report on the Observance of Standards and Codes \\
\hline $\mathrm{RP}$ & Repurchase \\
\hline RSSS & Recommendations for Securities Settlement Systems \\
\hline RTGS & Real Time Gross Settlement \\
\hline RTP & Royal Thailand Police \\
\hline SCT & Standard Chartered Thailand \\
\hline SDDS & Special Data Dissemination Standards \\
\hline SEA & Securities Exchange Act \\
\hline $\mathrm{SEC}$ & Securities and Exchange Commission \\
\hline SET & Stock Exchange of Thailand \\
\hline SFIs & Specialized Financial Institutions \\
\hline SMART & System for Managing Automated Retail Funds Transfer \\
\hline SMEs & Small- and Medium-Sized Enterprises \\
\hline $\mathrm{SRO}$ & Self-Regulatory Organizations \\
\hline STR & Suspicious Transactions Reports \\
\hline SWIFT & Society for Worldwide Interbank Financial Telecommunication \\
\hline TAMC & Thailand Asset Management Corporation \\
\hline TBMA & ThailandBond Market Association \\
\hline
\end{tabular}


TF

TFEX

TSD

UOBT

URR
Terrorist Financing

Thailand Future Exchange

Thailand Securities Depository Co., Ltd.

United Overseas Bank Thailand

Unremunerated Reserve Requirement 


\section{EXECUTIVE SUMMARY}

A great deal has been accomplished since the 1997 financial crisis to strengthen the soundness and resilience of the Thailand financial sector (Appendix I). Macroeconomic management has significantly improved through the implementation of a fiscal sustainability framework and adoption of a floating exchange rate regime and inflation targeting, along with enhanced monetary transparency. Major weaknesses revealed by the crisis in the regulatory and supervisory framework have largely been addressed. Thailand corporations, which had been at the center of the crisis, have also significantly deleveraged and upgraded their governance practices. Domestic capital markets have developed over the past decade, in part in response to the large funding needs of the government and banks following the crisis. This has strengthened the resilience of the financial system.

\section{Banking fundamentals have strengthened, with most Thailand banks reporting high} levels of capital and solid profitability. Thailand banks have restructured and rebuilt their balance sheet following the huge losses suffered during the crisis. Banks' risk adjusted capital adequacy ratio averaged 15 percent at end-2007, well above the regulatory minimum of $8 \frac{1}{2}$ percent. Operating profitability has improved for most banks due to higher interest margins and strong loan growth. At the same time, better credit underwriting and efforts by the BOT to improve provisioning coverage against distressed assets has lowered the overall risk profile of the Thailand banking sector. Two weaker banks have been recapitalized, and one is now in the process of being privatized.

\section{Banks and other financial institutions have also remained resilient in the face of the recent turmoil in mature credit markets and heightened market volatility. Standard market indicators suggest that default probabilities are low, reflecting the low direct exposure to structured products and to foreign funding. The Stock Exchange of Thailand (SET) rose strongly in 2007, recovering losses that resulted from investors pulling back at end-2006 and again mid-year.}

Nonetheless, stress tests show that banks are vulnerable to a sharp domestic economic slowdown, primarily from credit risk. This reflects banks' large holdings of loans on their balance sheet. Liquidity risk was also found to be material for a few banks, notwithstanding the current high liquidity in the banking system. Market and contagion risks were more modest, largely reflecting banks' limited holdings of securities, use of hedging instruments, and low interbank and international exposure.

\section{Moreover, the authorities face several critical challenges in enhancing financial soundness and efficiency. First, there is a need for continued and close supervisory attention to weaker banks. Second, it is important to address remaining legacy problems associated with the financial crisis, in particular reducing the high level of nonperforming loans (NPLs) and nonperforming assets (NPAs) in the financial system (in both banks and state-owned asset}


management companies (AMCs)). Third, the credit culture should be further strengthened to avoid a similar build up of NPLs in the future by facilitating banks taking more effective and quicker action against defaulted borrowers. Fourth, the authorities should move ahead with their planned intention to introduce a limited deposit insurance scheme to reduce the moral hazard problems associated with a blanket deposit guarantee (see Box 1).

Although Thailand generally shows a high level of observance of international financial sector standards and codes, the effectiveness of the current supervisory and regulatory framework is potentially undermined by a weak legal underpinning and insufficient $d e$ jure independence. Many of these problems have long been identified but progress has been slow, in particular on issues that have required action by the government. The team urged that passage of stalled legal reforms in the financial sector should be a high priority, including by giving the BOT full authority to regulate, supervise, and take enforcement actions with respect to BOT-supervised deposit-taking institutions. Since the FSAP, several important financial sector laws were passed (Box 2).

While the insurance sector appears to be sound and profitable, its regulatory and supervisory framework needs to be upgraded. High priority reforms are: (i) establishing a new, independent supervisory agency; (ii) moving gradually toward risk-based supervision and solvency capital regimes; and (iii) introducing a policy-holder protection scheme. The authorities should undertake stress testing to comprehensively assess the sector's vulnerabilities.

As the differences among the banking, insurance, and securities sectors blur, effective coordination among financial regulators is crucial. Coordination should be enhanced through more timely information sharing and collaboration on proposed regulatory and policy changes, especially at the staff working level, and greater consultations with market participants.

The government should re-evaluate its considerable role in the financial sector and reduce its equity stake in private financial institutions. Government ownership of deposittaking SFIs and equity stakes in several private commercial banks have created the appearance of an unlevel playing field and selective regulatory forbearance. A comprehensive, medium-term strategy should be developed that clarifies the respective roles of private commercial banks, government-owned commercial banks, and SFIs. Deposittaking SFIs should be regulated and supervised like commercial banks.

Addressing the systemic risks in the payment and securities settlement system and bringing the Anti-Money Laundering/Combating the Financing of Terrorism (AML/CFT) framework in line with international standards would enhance the integrity of the financial market infrastructure. The finality of settlement of interbank transactions should not be subject to challenge in the event of bankruptcy. In addition, both 
the Securities and Exchange Commission (SEC) and the Thailand Securities Depository Company Co., Ltd. (TSD) should have the authority and capacity to respond to financial failures by market participants. The AML/CFT framework needs to brought into line with the requirements of the FATF 40+9 Recommendations and effective mechanisms need to be in place to implement and monitor Thailand's AML/CFT regime. To this end, the Anti-Money Laundering Act 1999 (AMLA) will need to be amended. 


\section{Box 1. Thailand: Key FSAP Recommendations}

Supervisory regime

- Passage of pending legal reforms to address weaknesses in the financial supervisory framework, including establishing legal independence of the heads of the supervisory agencies and provisions for objective and transparent standards for dismissal.

- Strengthen the supervisory framework for insurance by establishing an independent supervisory board and moving to risk-based supervision and capital regimes.

- Improve coordination among the supervisory agencies through regular consultations and greater sharing of drafts policies and regulations at the staff level. Improve process of consultations with market participants.

\section{Financial safety net framework}

- Transition from a blanket guarantee to a limited deposit insurance system.

Medium-term priority

\section{Central bank independence and transparency}

- Assure full legal and operational independence of the BOT in the conduct of monetary policy.

- Clarify in the BOT Act the primary objectives of monetary policy.

\section{Prioritization}

Immediate priority

Immediate priority

Medium-term priority

\section{Role of the government in the banking sector}

- Gradually reduce the government's equity stakes in the private commercial banks.

- Re-evaluate the appropriateness of SFIs taking deposits in competition with commercial banks. If SFI take deposits, they should be regulated and supervised like commercial banks.

\section{Distressed asset resolution}

- Reduce the large stock of NPLs and distressed assets in the Thailand financial sector and state-owned asset management companies.

- Accurately identify and monitor the level and aging of NPLs in banks.

- Address weaknesses in the legal infrastructure, including banks' ability to seize collateral of defaulted borrowers.

- Provide tax incentives for writing off NPLs.

\section{Financial Infrastructure and Integrity}

- Bring the AML/CFT framework in line with the international standard by amending the 1999 AMLA.

- Amend the law to reduce the legal risk to the finality of the settlement of interbank transactions in the event of bankruptcy and reduce systemic risks in the securities settlement system.

- Legally separate the Central Securities Depository (CSD) and the Central Counterparty (CCP) functions.

Medium-term priority Medium-term priority

Medium-term priority

Immediate priority Immediate priority

Medium-term priority

Immediate priority

Medium-term priority

Medium-term priority 


\section{Box 2. Thailand: Recent Reforms to the Financial Sector Institutional Framework}

Since the FSAP discussions, Thailand has passed a number of critical legal financial sector reforms. The bulk of these were passed in December of 2007. The amended BOT Act (except sections related to the Deposit Protection Agency Act, which will be effective in August 2008) and the amended Securities and Exchange Act have come into effect since March 2008, while the Financial Institutions Business Act and the Deposit Protection Agency Act will go into effect August 2008. The Office of Insurance Commission Act was passed in August 2007. These reforms address most of the legal and regulatory shortcomings identified in the assessments of the standards. For instance, the formal inclusion of the Secretary Generals of the Office of Insurance Commission and Securities and Exchange Commission in the Financial Institutions Policy Committee (FIPC) helps improve coordination among regulators with regard to critical matters affecting the financial system. Key benefits of these legal reforms:

\section{Amendments to the BOT Act}

- The objectives of the BOT to achieve monetary stability, payment system stability and financial stability, are now explicitly spelled out in the law.

- The BOT has full operational independence to achieve the monetary objectives. It no longer has to receive the Ministry of Finance (MOF) approval for new issuance of its own bills for liquidity management. It can also pay interest on banks' uncollateralized deposits held at the BOT.

- Selection and dismissal of the BOT governor and the length of term of the Governor and Board Chairman have been defined. In addition, the terms, qualifications and responsibilities of policy committee members (Monetary Policy Committee, Financial Institution Policy Committee and Payment System Committee), the Governor and the Board of Directors have been defined.

- Financial transparency is enhanced by defining auditing and reporting requirements.

\section{Financial Institutions Business Act (FIBA)}

- The FIBA makes the BOT the sole regulator of commercial banks. The relationship between the MOF and the BOT has been clearly spelled out, improving transparency and accountability.

- While licensing power remains with the MOF, the BOT can now close an institution.

- The Act gives the BOT right to conduct consolidated supervision and explicitly anchors the prompt correction action framework in the law. Fit and proper criteria for bank managers and board members have been defined.

\section{Deposit Protection Agency (DPA) Act}

- The blanket deposit guarantee will be replaced with a limited deposit insurance. The new scheme, which will go into effect August 11, 2008, will be phased in over 5 years. The first year will have full coverage and will then gradually be reduced to B 1 million (equivalent to about US $\$ 33,000$ at current exchange rate).

- A premium will be collected by the Deposit Protection Agency (DPA) to fund the deposit insurance. The initial capital of B 1 billion will be funded by the government. The DPA will act as liquidator in the case of failed and closed financial institutions.

\section{The Office of Insurance Commission Act}

- Introduction of an independent regulator-the Office of the Insurance Commission.

- Movement toward risk-based capital regulatory framework for nonlife and life insurance.

- Movement toward International Accounting Standards (IAIS) Insurance Core Principles and early warning systems, which offer rating-based approaches.

\section{Securities and Exchange Act}

- The Act gives the SEC power to provide information/assistance upon request of foreign capital market regulators without its own interest in the matter.

- The SEC and Thailand Securities Deposit Corporation are given the authority to act in the event that a licensed broker fails.

- The MOF is no longer appointed Chairman of the Board of the SEC. 


\section{Current Macroeconomic And Financial EnVironment}

\section{A. Macroeconomy}

1. Economic developments were broadly favorable for the financial sector over the past two years (Figure 1). GDP growth averaged 5 percent in 2006 and 2007, supported by strong net exports. Domestic demand weakened reflecting the negative impact of political developments and higher oil prices. Inflation declined steadily from its peak in May 2006 to well within BOT's target band. Property prices also continued to rise, helping to support collateral values and spur demand for housing-related credit. Corporate profitability strengthened further on the back of rising profit margins and sales (Figure 2). The household sector's financial position also improved, despite higher debt acquired largely to finance housing, due to positive real wage growth and rising housing prices (Figure 3). Household debt at about 30 percent of GDP at end-2005 is moderate compared to regional averages. ${ }^{1}$

\section{Macroeconomic policy management faced the challenge in 2006 and through 2007} of high capital inflows, a rising baht, and weak domestic demand. Faced with a rapid appreciation of the baht and surging external inflows, the authorities in late 2006 introduced wide-ranging capital controls (i.e., a 30 percent unremunerated reserve requirement (URR). Investors reacted negatively. The SET fell 15 percent the day after the announcement and bond yields increased sharply. Financial institutions were not significantly impacted by this market reaction nor subsequent ones, such as the mid-2007 repricing of risks in the mature markets, because of their low exposure to structured products and market risks. ${ }^{2}$ The BOT has since removed the URR and the SET index has gained 26 percent in value during 2007. In response to weaker domestic demand and declining inflation, the BOT cut its main policy rate by 175 basis points since early 2007 while fiscal policy provided a small stimulus.

\section{The near-term macroeconomic outlook remains favorable to the financial sector,} although slower growth could pose challenges. Owing to their large exposure to corporate loans and slow progress made in addressing outstanding legacy issues, stress tests show that Thailand banks are vulnerable to a sharp slowdown in growth. The main channel of macroeconomic risks for the Thailand economy and financial sector are: (i) a significant deterioration in global economic growth, with exports accounting for over two-thirds of GDP; and (ii) domestically, political uncertainties and delayed implementation of major public investment projects continuing to act as drag on domestic demand and the investment climate. A

\footnotetext{
${ }^{1}$ Derived from the national household socioeconomic survey data which are conducted every two years.

2 Thailand commercial banks' total exposure to foreign securities and structured investments such as Collateral Debt Obligations (CDO) and structured notes amounted to less than 2 percent banks' total assets attend of June 2007. One bank with a moderate trading book exposure in CDOs is under BOT's supervisory watch.
} 
Figure 1. Thailand: Economic Indicators
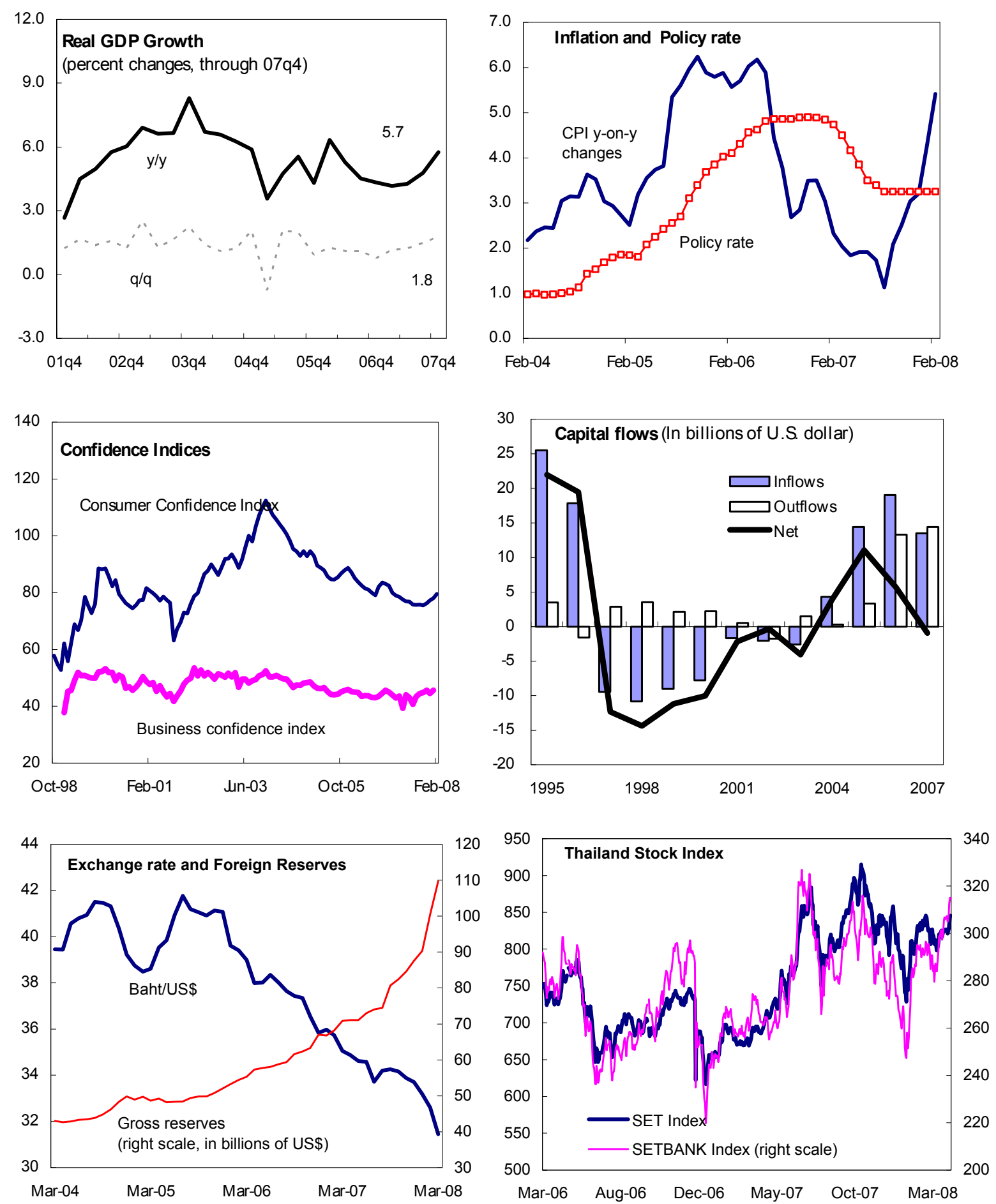

Source: Bank of Thailand. 
Figure 2. Thailand Corporate Financial Indicators
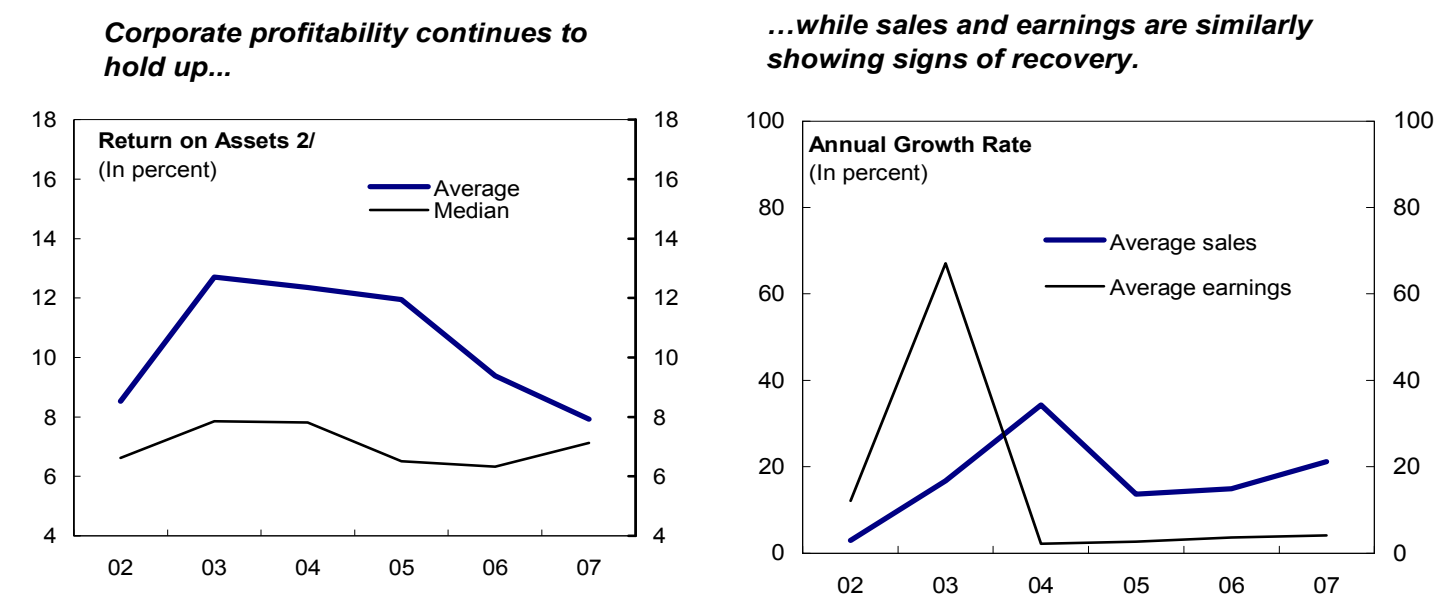

Interest costs have been stable...

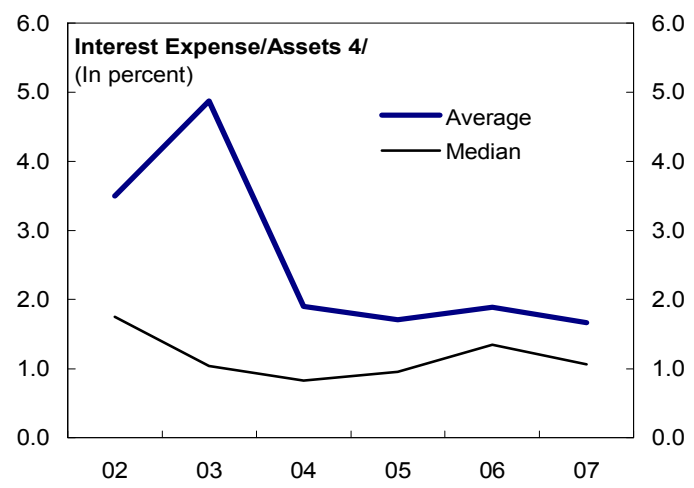

....and the interest coverage has improved somewhat.

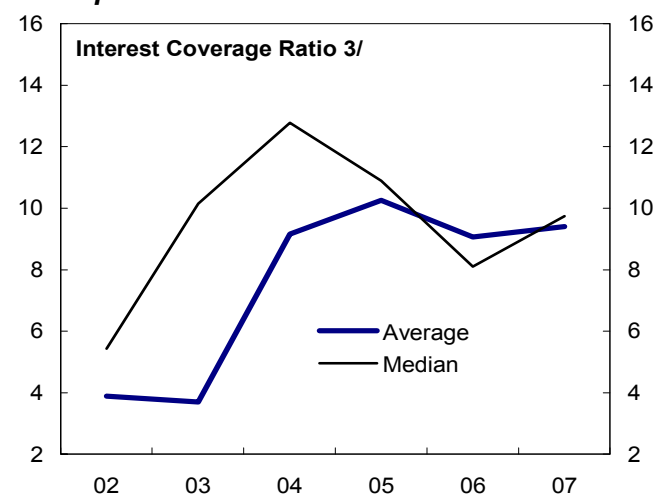

Liquidity indicators are sufficient...

....and the debt burden continues to moderate.
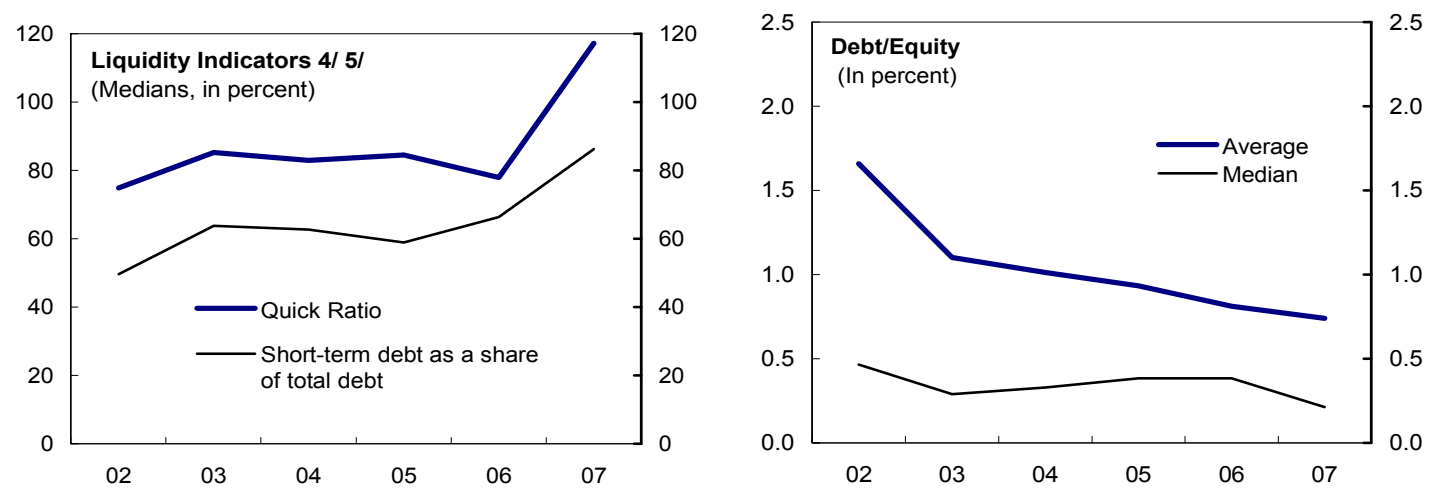

Sources: Worldscope; and Fund staff calculations. 1/ Based on 321 listed nonfinancial firms.

2/ Return on Assets $=$ Net Income/Total Assets.

3/ Interest Coverage Ratio = Earnings Before Interest, Taxes and Depreciation/Interest Expense.

$4 /$ The rapid increase in company coverage over the last three years distorts some of the ratios, such as interest/assets and short-term debt for 2004.

5/ Quick Ratio = (Cash + Accounts Receivable $) /$ Current Liabilities. 
Figure 3. Thailand: Household Financial Indicators

Property prices have recovered, and exceed levels of end-1997

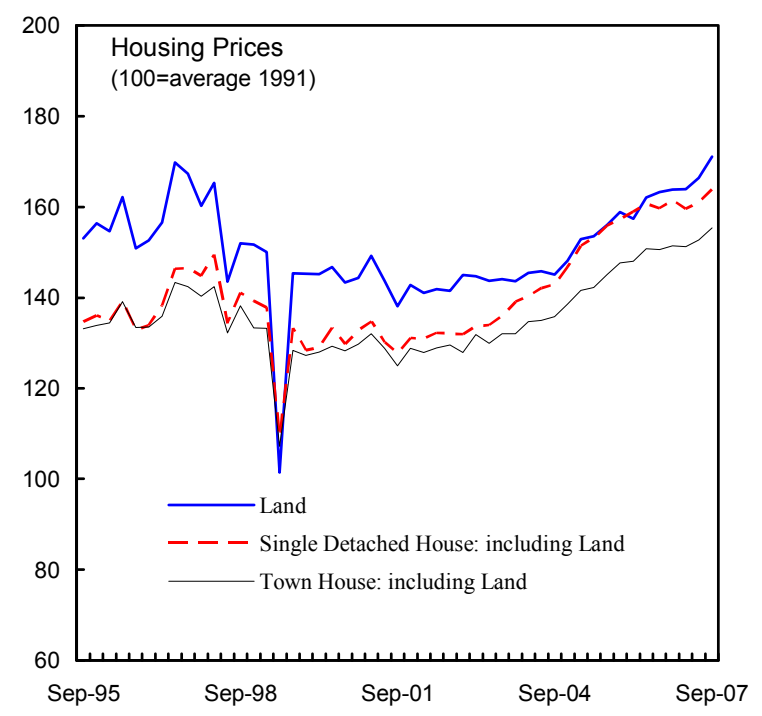

Household borrowing has increased, with SFIs and commercial banks primary lenders

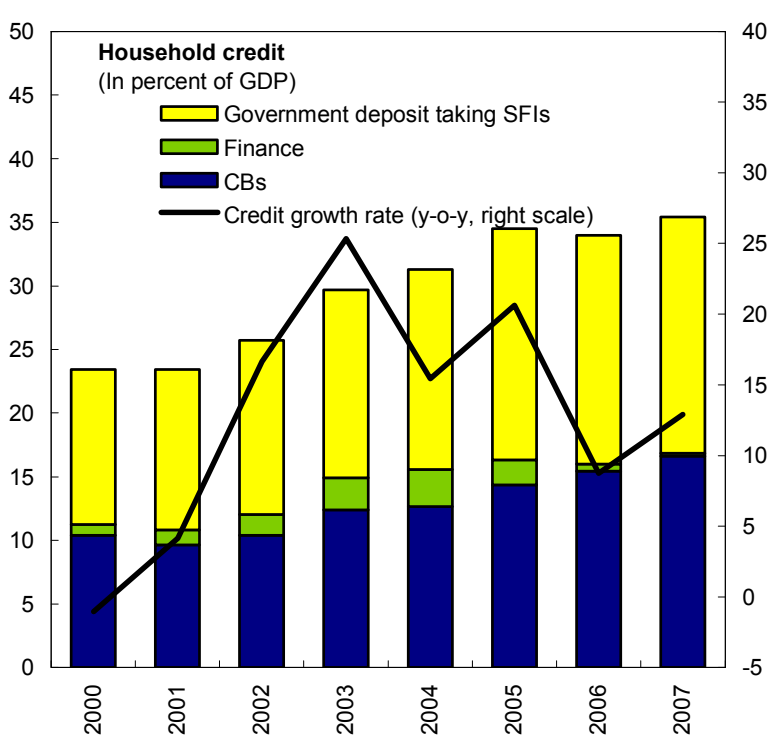

Wages have increased in real terms

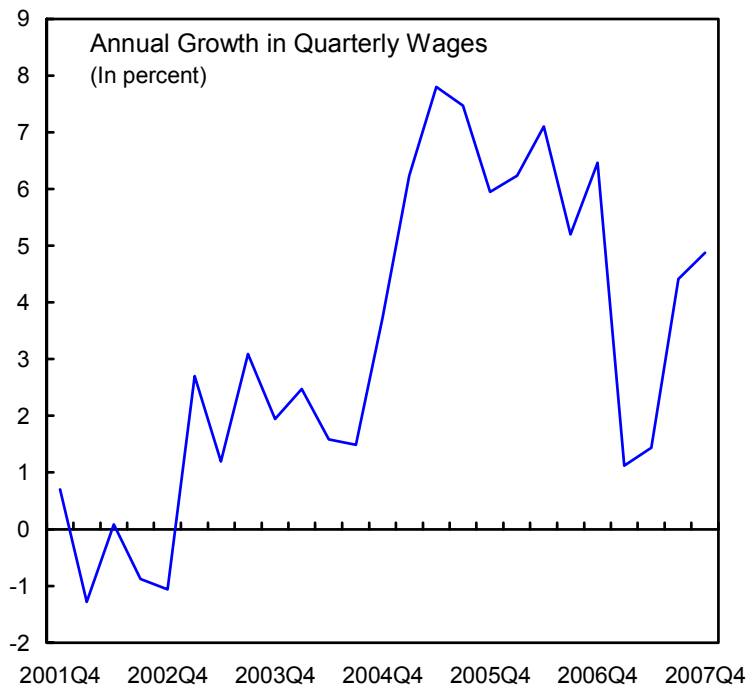

Nothwithstanding, houshold debt remains reasonable by most regional standards.

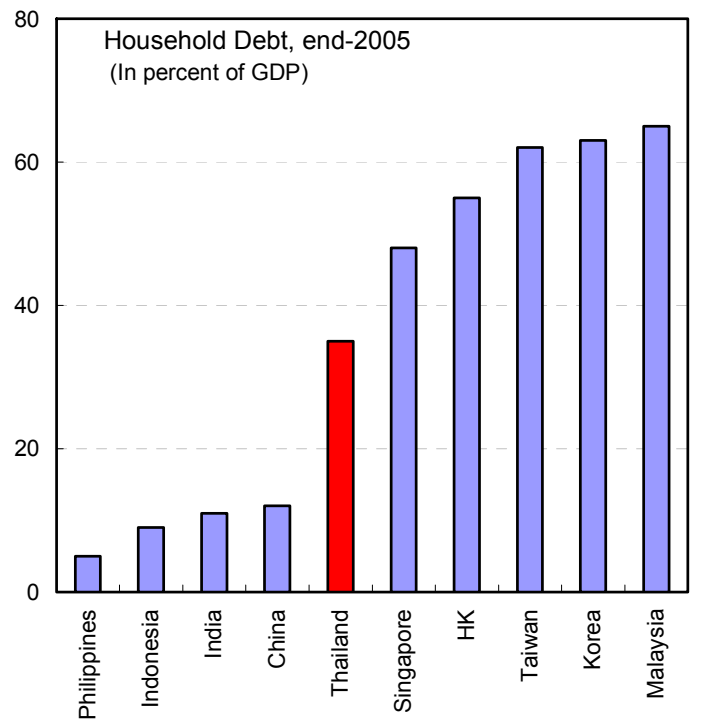

Sources: Thai authorities; Global Financial Stability Reports (IMF), and CEIC database. 
protracted slowdown would also hurt Thailand banks' ability to lower their nonperforming assets.

\section{B. Financial Sector}

4. The Thailand financial sector is relatively large, with assets close to $\mathbf{1 8 0}$ percent of GDP. It is bank centered, although capital markets and nonbank financial institutions are assuming a more prominent role (Table 1). Commercial banks account for 60 percent of financial sector assets. SFIs - which are government-owned, in most cases are deposit-taking, and are intended to promote the government's social and economic development - account for another 14 percent. Nonbank financial institutions hold the remaining 25 percent of financial assets. Many of them (e.g., leasing, asset management, insurance, and securities companies) are subsidiaries of local banking groups.

\section{Deposit-taking financial institutions}

5. The deposit-taking financial system underwent a major restructuring over the past decade. This includes: (i) the closure and mergers of a number of finance companies; (ii) the implementation of the government's Financial Sector Master Plan, resulting in new entrants, mergers, and the formation of new banking conglomerates; and (iii) ownership changes from private bank recapitalizations, government intervention in banks, and the sale of two banks to foreign investors.

6. Foreign-owned banks play an important but limited role. Foreign banks accounted for about 18 percent of total banking assets at end-March 2007-in line with many emerging market countries. ${ }^{3}$ In accordance with BOT rules, they operate mostly as single branches, with only two full-service foreign-owned commercial banks. While a one branch policy restricts the size and scope of their retail banking activities, some have used outsourced distribution channels with support from internet banking and telemarketing to penetrate the retail market. Most foreign banks are focused on the wholesale market. Domestic banks do not have a major presence abroad. Despite some entry restrictions, the banking sector does not appear concentrated, with the Herfindahl index at $910 .{ }^{4}$

7. Despite considerable divestiture since the crisis, the government continues to maintain a significant equity stake in the commercial banking sector (Table 2). This equity stake resulted from the 1997 financial crisis, and while the government has since

\footnotetext{
${ }^{3}$ This includes the shares of fully foreign owned Standard Chartered Thailand (SCT) and United Oversees Bank Thailand (UOBT) as well as the market shares of the foreign branches.

${ }^{4}$ Based on end-March 2007 data for all individual banks' market share (local banks and foreign branches). When the Herfindahl index is between 1000-1800, the market structured is viewed as somewhat concentrated. If above 1800, highly concentrated, and if below 1000 not concentrated.
} 
Table 1. Thailand: Structure of the Financial System

(In billions of baht)

\begin{tabular}{|c|c|c|c|c|c|c|}
\hline & 1996 & $\begin{array}{l}\text { In percent } \\
\text { of total } \\
\text { financial } \\
\text { assets }\end{array}$ & 2006 & $\begin{array}{l}\text { In percent } \\
\text { of total } \\
\text { financial } \\
\text { assets }\end{array}$ & 2007 & $\begin{array}{l}\text { In percent } \\
\text { of total } \\
\text { financial } \\
\text { assets }\end{array}$ \\
\hline Financial Sector Assets & 10,004 & & 13,965 & & 14,924 & \\
\hline In percent of GDP & 217.0 & & 178.7 & & 175.9 & \\
\hline \multicolumn{7}{|l|}{ Deposit-taking financial institutions } \\
\hline Banks & 5,537 & 55 & 8,653 & 62 & 9,006 & 60 \\
\hline Private banks & 3,859 & 39 & 5,691 & 41 & 5,981 & 40 \\
\hline 3 largest private banks & 2,343 & 23 & 3,407 & 24 & 3,680 & 25 \\
\hline Others privately owned & 1,516 & 15 & 2,284 & 16 & 2,301 & 15 \\
\hline State-owned & 1,206 & 12 & 1,835 & 13 & 1,823 & 12 \\
\hline Foreign-majority owned & 472 & 5 & 1,127 & 8 & 1,202 & 8 \\
\hline Subsidiaries & 0 & 0 & 12 & 0 & 12 & 0 \\
\hline Branches of foreign banks & 472 & 5 & 1,115 & 8 & 1,190 & 8 \\
\hline Specialized Financial Institutions (excluding state AMCs) 1/ & 718 & 7 & 2,015 & 14 & 2,075 & 14 \\
\hline (in percent of total financial sector assets) & 7.2 & 0 & 14.4 & & & \\
\hline of which deposit-taking SFIs $\quad(4+$ SME Bank $)$ & 683 & 7 & 1,947 & 14 & 2,075 & 14 \\
\hline - Taking deposit currently & 683 & 7 & 1,891 & 14 & 1,961 & 13 \\
\hline - Non deposit taking & 0 & 0 & 56 & 0 & 114 & 1 \\
\hline Finance Companies & 1,767 & 18 & 81 & 1 & 47 & 0 \\
\hline Credit Fonciers & 9 & 0 & 2 & 0 & 0 & 0 \\
\hline \multicolumn{7}{|l|}{ Non-Bank Financial Instiutions } \\
\hline Insurance companies & 235 & 2 & 833 & 6 & 953 & 6 \\
\hline Life & 146 & 1 & 700 & 5 & 816 & 5 \\
\hline Mixed & 0 & 0 & 0 & 0 & 0 & 0 \\
\hline Nonlife & 89 & 1 & 133 & 1 & 137 & 1 \\
\hline of which: state-owned & 0 & 0 & 0 & 0 & 0 & 0 \\
\hline Mutual Funds 2/ & 247 & 2 & 1,050 & 8 & 1,437 & 10 \\
\hline Securities dealers (brokers) & 1,491 & 15 & 123 & 1 & 142 & 1 \\
\hline Pension Funds 3/ & n.a. & n.a. & 667 & 5 & 755 & 5 \\
\hline of which: state-owned & 0 & 0 & 276 & 2 & 313 & 2 \\
\hline Leasing Companies & n.a. & $\ldots$ & n.a. & $\ldots$ & n.a. & $\ldots$ \\
\hline Venture Capital Companies & n.a. & $\ldots$ & 1 & 0 & n.a. & $\ldots$ \\
\hline Asset Management Companies (AMCs) & n.a. & $\ldots$ & 540 & 4 & 509 & 3 \\
\hline State-owned & n.a. & $\ldots$ & 461 & 3 & 437 & 3 \\
\hline Privately-owned & n.a. & $\ldots$ & 79 & 1 & 72 & 0 \\
\hline \multicolumn{7}{|l|}{ Number of Insitutions } \\
\hline Commercial Banks & 29 & & 34 & & 34 & \\
\hline SFIs & 4 & & 6 & & 6 & \\
\hline of which deposit-taking SFIs & 4 & & 4 & & 4 & \\
\hline Finance Companies & 91 & & 6 & & 5 & \\
\hline Credit foncier & 12 & & 4 & & 3 & \\
\hline Insurance companies & 76 & & 99 & & 98 & \\
\hline Mutual Funds 2/ & 205 & & 726 & & 830 & \\
\hline Securities dealers (brokers) & 83 & & 41 & & 43 & \\
\hline Pension Funds 3/ & n.a. & & 526 & & 514 & \\
\hline Leasing Companies & n.a. & & n.a. & & n.a. & \\
\hline Venture Capital Companies & 0 & & 2 & & 2 & \\
\hline $\mathrm{AMCs}$ & 0 & & 15 & & 15 & \\
\hline \multicolumn{7}{|l|}{ Memorandum items: } \\
\hline Nominal GDP & 4,611 & & 7,813 & & 8,485 & \\
\hline
\end{tabular}


Table 2. Thailand: Developments in the Government's Equity Stake of Thailand Banks ${ }^{1}$ (In percent of total)

\begin{tabular}{lrrrrrrrrrrr}
\hline & 1997 & 1998 & 1999 & 2000 & 2001 & 2002 & 2003 & 2004 & 2005 & 2006 & $20072 /$ \\
\hline Bank Thai & 7.4 & 100.0 & 100.0 & 100.0 & 96.3 & 49.0 & 49.0 & 49.0 & 49.0 & 49.0 & 32.9 \\
KTB 3/ & 57.3 & 99.1 & 90.9 & 90.9 & 90.9 & 90.9 & 90.9 & 60.1 & 56.4 & 56.3 & 55.5 \\
TMB & 0 & 0 & 0 & 0 & 10.3 & 10.3 & 10.3 & 10.3 & 31.2 & 31.2 & 31.2 \\
SCIB & 8.5 & 100.0 & 100.0 & 100.0 & 100.0 & 100.0 & 100.0 & 79.0 & 47.6 & 47.6 & 47.6 \\
SCBT & 0 & 0 & 25.0 & 25.0 & 25.0 & 25.0 & 25.0 & 25.0 & - & - & - \\
SCB 4/ & 4.0 & 2.6 & 2.6 & 2.4 & 2.1 & 1.7 & 1.3 & 1.0 & 0.9 & 0.8 & 0.8 \\
\hline
\end{tabular}

Source: Thai Authorities.

1/ Data reflects developments in the government's equity stake in large Thai banks, a number of which received government support during the 1997 financial crisis. The government also has equity holdings in other smaller banks, including Tbank and ACL.

2/ Latest data observation August 2007.

3 / The government intervened in KTB in the 1980 s.

4/ 2007 data reflects the common shares held by the Ministry of Finance of Siam Commercial Bank. The government via Vajupuk Funds

also holds preferred shares of SBC. The government's shareholdings of SBC amounted to 19 percent at end-August 2007.

reduced its participation in these banks, the pace of divestiture has slowed in recent years. It currently has controlling interests in three banks and significant shares in three other large local banks as well as a number of smaller banks. These banks accounted for 41 percent of total commercial banking sector assets at end-2006.

\section{Banking fundamentals continue to strengthen, with most banks reporting high} capital levels and solid operating profitability (Table 3, Figure 4). The average risk weighted capital adequacy ratio (CAR) for Thailand banks was 15 percent at end-2007, well above the regulatory minimum ( $81 / 2$ percent), supported by a high level of Tier 1 capital and a strong leverage ratio. While banks have reported strong operating profits since 2004, driven by higher margins and moderate loan growth, net profits fell in 2006 and 2007 due to large provisioning requirements arising from the phased introduction of IAS 39. Banks' return on assets (ROA) fell to 0.3 percent in 2007 compared to 1.4 percent for 2005 . The three largest private banks achieved full compliance with IAS 39 at end-2006. Other banks, some which raised additional capital including through new foreign strategic partners, phased in their compliance during 2007. Two state-banks with low capitalization are being closely supervised by the BOT.

\section{Since the financial crisis, banks have diversified their revenue base, which has} helped improve their risk profile. Banks have focused on expanding their services to retail customers and small- and medium-sized enterprises (SMEs). This has helped them diversify their loan and revenue base, reduced earnings volatility and lowered the concentration risk associated with lending to larger corporates. Concerned over the rapid pace of consumer lending, starting in 2004 the BOT introduced a series of prudential measures to strengthenlending standards. ${ }^{5}$ These measures have contributed to a reduction in the pace of

\footnotetext{
${ }^{5}$ These include: (i) increasing minimum installment repayments on credit card debt outstanding; (ii) minimum qualifying income for credit cards and interest rate ceilings on credit card charges; (iii) imposing stricter credit
} 
lending over the past two years and there was no evidence that the rapid growth had resulted in rising consumer NPLs.

Table 3. Thailand: Banks' Profitability and Solvency Indicators ${ }^{1}$ (In percent)

\begin{tabular}{|c|c|c|c|c|}
\hline & 2005 & 2006 & 2007 & $\begin{array}{c}\text { Avg } \\
2000-07\end{array}$ \\
\hline Return on Assets (ROA), all banks & 1.4 & 0.8 & 0.3 & 0.7 \\
\hline Private banks ${ }^{1 /}$ & 1.4 & 0.7 & 0.2 & 0.3 \\
\hline State-owned banks & 1.1 & 0.8 & -0.1 & 1.5 \\
\hline Foreign branches & 1.4 & 0.9 & 1.4 & 1.2 \\
\hline Return on Equity (ROE), all banks & 12.1 & 7.1 & 7.1 & 8.1 \\
\hline Private banks ${ }^{1 /}$ & 15.8 & 7.7 & 7.7 & 1.5 \\
\hline State-owned banks & 16.3 & 10.4 & 10.4 & 30.3 \\
\hline Foreign branches & 4.8 & 4.2 & 4.2 & 3.6 \\
\hline Capital Adequacy Ratio (in \% of RWA) ${ }^{2 /}$ & 13.0 & 13.6 & 14.6 & 13.1 \\
\hline Private banks ${ }^{1 /}$ & 13.5 & 13.9 & 14.9 & 13.3 \\
\hline State-owned banks & 11.7 & 12.7 & 13.5 & 12.4 \\
\hline Regulatory Tier 1 Capital (in \% of RW A) ${ }^{2 /}$ & 9.8 & 10.7 & 11.7 & 9.5 \\
\hline Private banks $^{1 /}$ & 10.1 & 10.9 & 12.0 & 9.3 \\
\hline State-owned banks & 8.9 & 10.2 & 10.5 & 10.4 \\
\hline Leverage ratio (capital in percent of assets) ${ }^{2 /}$ & 7.6 & 7.6 & 8.4 & 10.6 \\
\hline Private banks ${ }^{1 /}$ & 8.5 & 8.4 & 9.4 & 12.1 \\
\hline State-owned banks & 5.0 & 5.2 & 5.0 & 7.0 \\
\hline
\end{tabular}

\section{Considerable efforts have also been made to strengthen banks' capital position} and enhance their risk management practices. Recent regulatory measures include revisions to loan loss provisioning guidelines to comply fully with IAS by end-2007. This has led to higher provisioning charges for the banking system as a whole (Figure 5), although a few large and mid-sized banks still have low loan loss coverage. The BOT has also adopted a conservative approach to Basel II implementation, now expected at the end of 2008. Banks are aligning their risk management practices and Information Technology systems for the move to Basel II and all but one bank have indicated they intend to adopt the standardized approach.

\section{BANKIng StABILITy}

\section{Despite considerable efforts to improve banking soundness and lower NPLs, Thailand banks remain exposed to large holdings of NPAs and restructured loans.}

line limits for personal loans; and (iv) setting the maximum loan-to-value ratio at 70 percent for mortgage loans exceeding B 10 million. 
Figure 4. Thailand: Banking Sector Financial Soundness Indicators

Operating profits have held up well as a result of ...

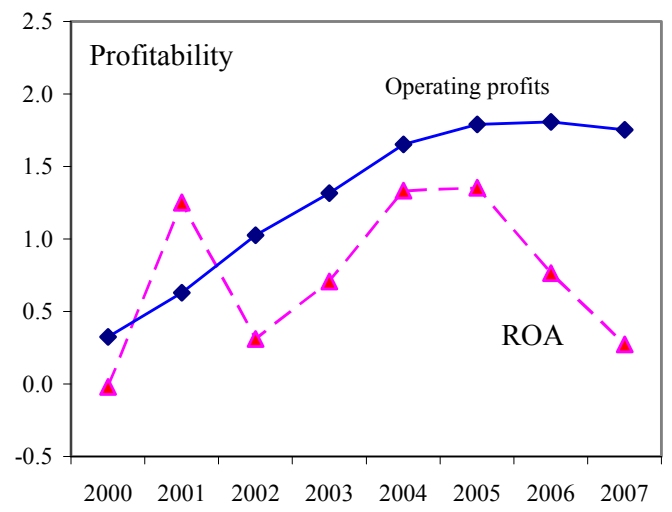

...offseting some increase in operating costs, reflecting mainly IT related spending

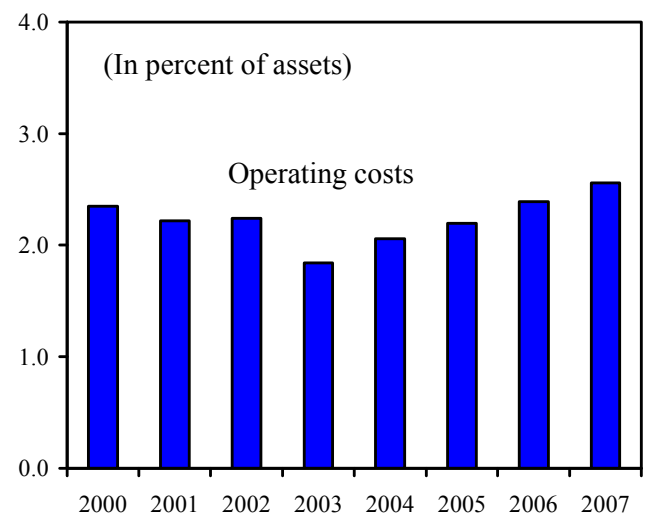

CAR is well above regulatory requirements

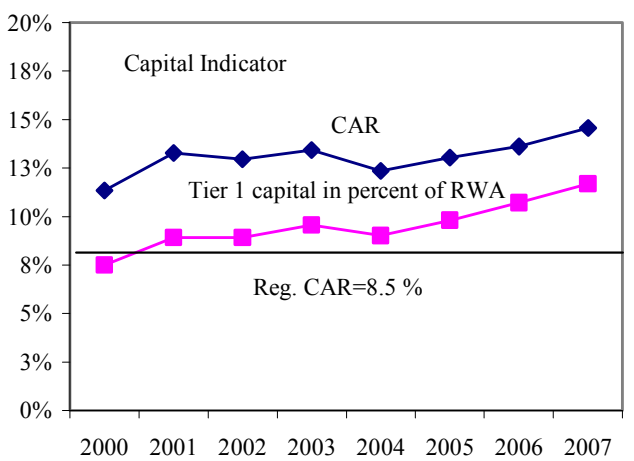

higher lending and strong margins...

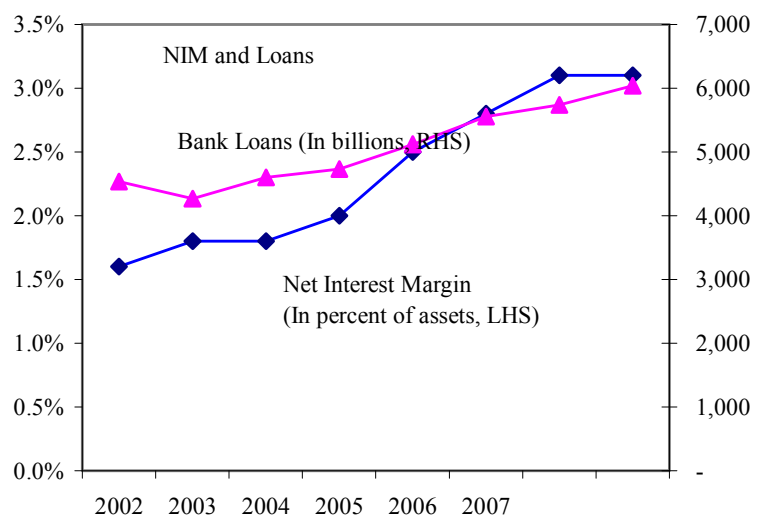

Higher provisioning impacted 2006/07 results due to phased introduction of IAS39

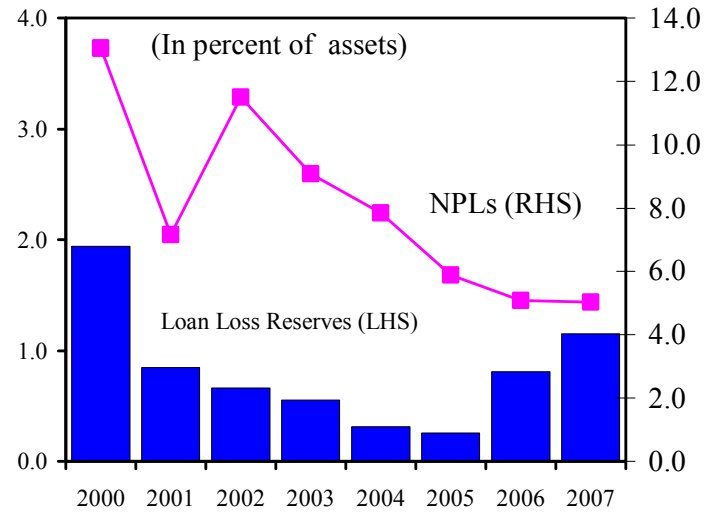

....and banks hold ample liquidity.

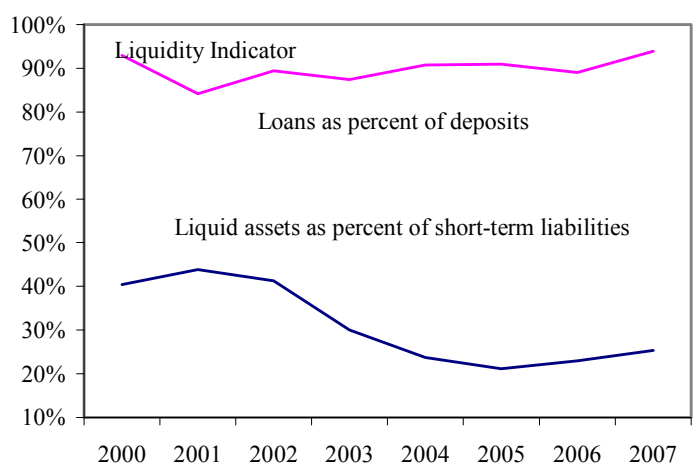

Source: Bank of Thailand, and staff calculations. 
Figure 5. Thailand: Distressed Assets and Loan Loss Provisions

NPLs have declined since the crisis.

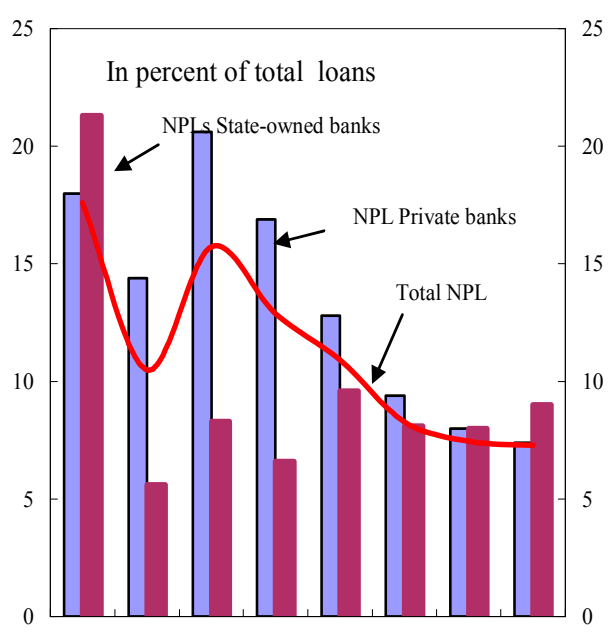

$2000 \quad 20012002 \quad 2003 \quad 2004 \quad 20052006 \quad 2007$

Loan loss provisioning has increased...

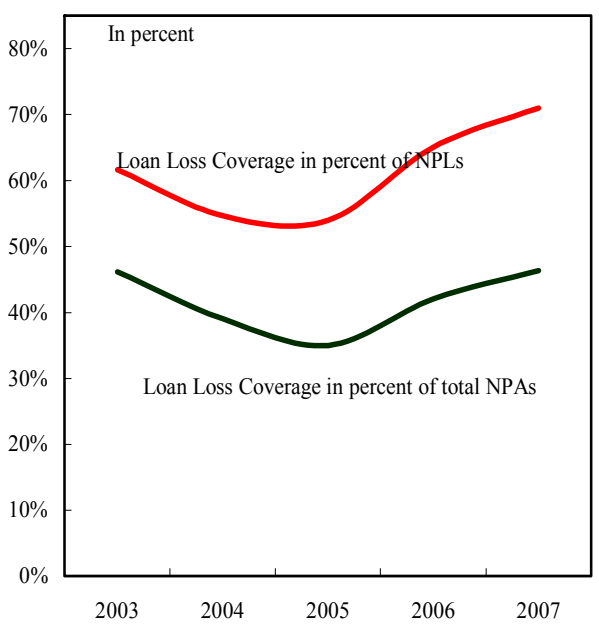

NPLs reflect mainly bad debts not written off for legal and tax reasons.

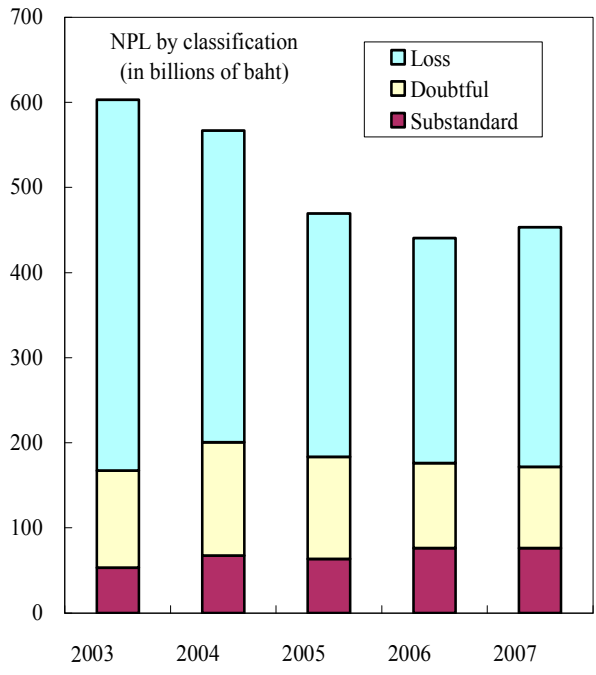

...but exposure to non-earning assets and restructured loans remains high.

2006 Level of Distressed Bank Assets ${ }^{1 /}$

Restructured loans
Baht 481 bn

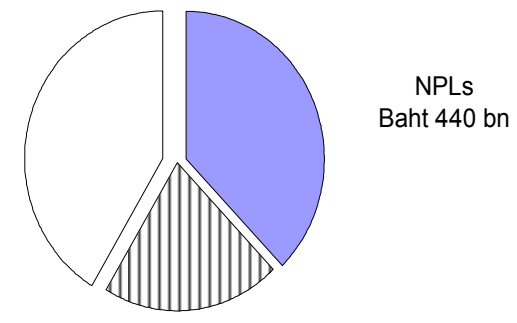

Other NPAs Baht 241 bn

Sources: Bank of Thailand, and staff calculations.

1/ The BOT does not collect or monitor the stock of restructured loans on a regular basis. Information for

2006 was collected as a result of a BOT survey. Restructured loans tend to have a relative high reentry to NPL status. 
Total NPLs among banks amounted to 7.3 percent of total loans at end-2007, a modest improvement from 8.3 percent in 2005 . This was driven primarily by lower NPLs among private banks. Most of the NPLs are loans that were previously restructured and have fallen back to NPL status or assets acquired through foreclosure. This figure may underestimate the problem given the high re-entry rate of previously restructured loans to NPL status and, until recently, lax guidelines governing classification of restructured loans. ${ }^{6}$ The magnitude of the problem is also higher if loans and foreclosed assets warehoused with the state-owned AMCs are included. The gross level of distressed assets in banks and AMCs amounted to B 1.5 trillion at end-2007, or 17.5 percent of GDP.

\section{Banks' large holdings of NPLs, the poor performance of restructured loans, questions regarding adequacy of provisioning levels, and unfinished legal reforms} weigh on banks' credit ratings and risk perception (Table 4, Figure 6). This is visible in the C/D rating in Fitch's Banking System Index, in the individual D ratings in Moody's Bank Financial Strength Rating (BFSR) and the Group 6 (scale of 1-10 with 1 the highest) Banking Industry Country Risk Assessment (BICRA) ranking by Standard and Poor's. ${ }^{7}$

Table 4. Thailand: 2007 Ratings of Six Largest Commercial Banks

\begin{tabular}{|c|c|c|c|c|c|}
\hline & \multicolumn{2}{|c|}{ Moody's } & \multirow{2}{*}{$\begin{array}{l}\text { Fitch } \\
\text { Individual }\end{array}$} & \multirow{2}{*}{$\begin{array}{l}\text { S\&P } \\
\text { Long term } \\
\text { Foreign Issuer }\end{array}$} & \multirow[b]{2}{*}{ Outlook } \\
\hline & $\begin{array}{l}\text { Long term } \\
\text { deposits }\end{array}$ & BSFR & & & \\
\hline Bangkok Bank (BBL) & Baal & $\mathrm{D}+$ & $\mathrm{C}$ & $\mathrm{BBB}+$ & Stable \\
\hline Krung Thai Bank (KTB) & Baal & D- & $\mathrm{C} / \mathrm{D}$ & BBB & Stable \\
\hline Siam Commercial bank (SCB) & Baal & $\mathrm{D}+$ & $\mathrm{C}$ & BBB & Stable \\
\hline Kasikornbank (Kbank) & Baal & $\mathrm{D}+$ & $\mathrm{C}$ & BBB & Stable \\
\hline $\mathrm{TMB}^{1 /}$ & Baa2 & D- & $\mathrm{C} / \mathrm{D}$ & $\mathrm{BB}+$ & Negative \\
\hline Bank of Ayudhya (BAY) $)^{1 /}$ & Baa3 & D- & $\mathrm{C} / \mathrm{D}$ & BBB- & Positive \\
\hline
\end{tabular}

Source: Moody's, Fitch, Standards and Poors (S\&P), and Bloomberg.

1/ Individual ratings for TMB and BAY were upgraded in 2007 due to capital raising efforts and the emergence of a major foreign strategic shareholder.

\footnotetext{
${ }^{6}$ As of end-2006, restructured loans amounted to 5.7 percent of total bank loans. On average, about 14 percent of such loans reenter into nonperforming status. There is no updated data on restructured loans for 2007.

${ }^{7}$ Fitch and Moody's industry ratings measure the strength of the banking system, based on individual ratings of the core banks in the system while abstracting from potential government support. Standard and Poor's looks at the strengths and weakness of the overall economy and banking industry, while also accounting for the government's history in intervening in the banking system.
} 
Figure 6. Thailand: Standard \& Poors' Distribution of BFSR Ratings for Systemically Important Banks in Asia (2007) ${ }^{1}$
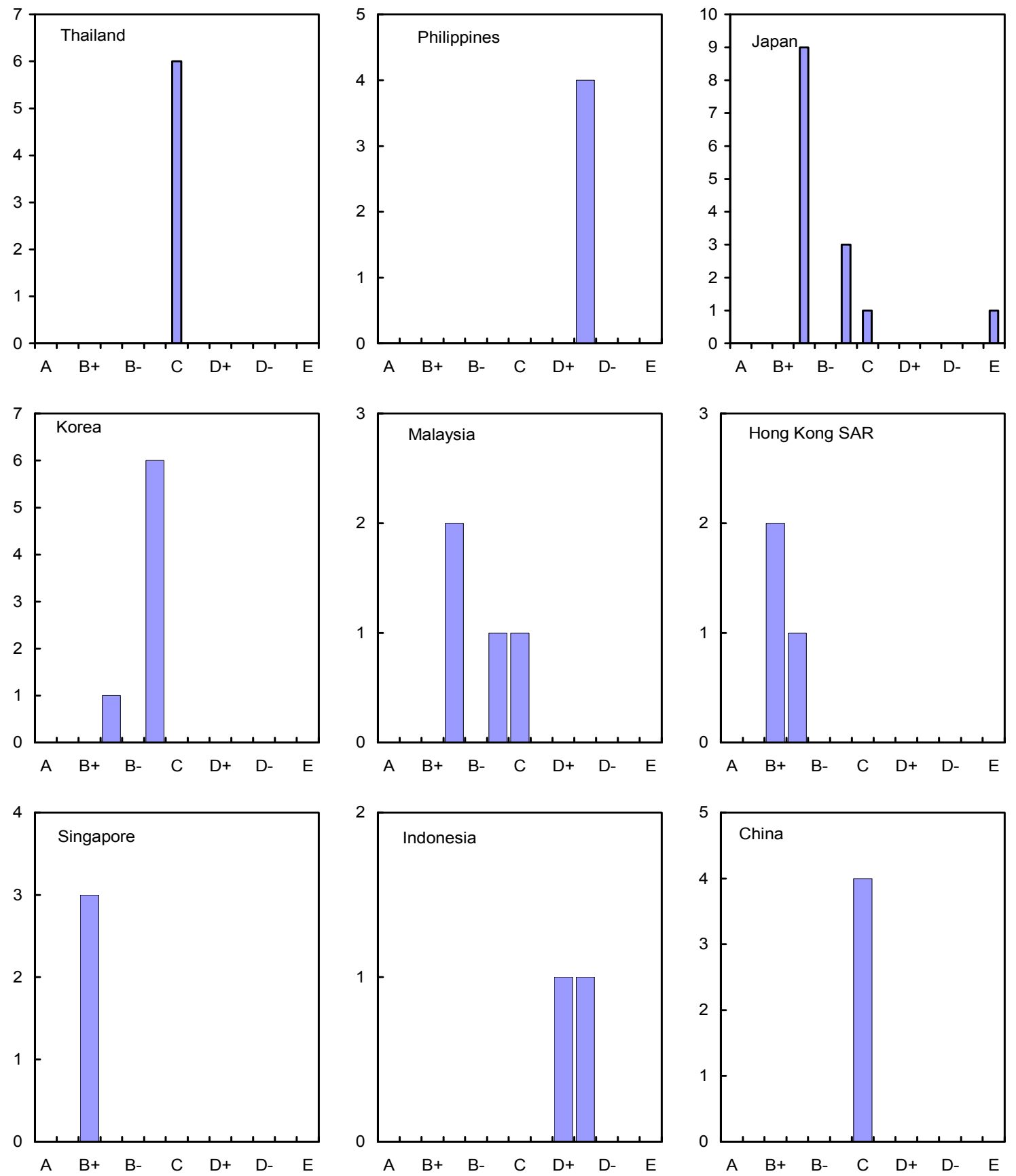

Source: Standards \& Poors

1/ Left hand side reflects the number of systemically important banks. The ratings reflect S\&P's bank's standalone credit ratings, represented by the Bank Fundamental Strength Rating (BFSR). BFSR is based on an asssessment of a bank's fundamental strengths. 'A' reflects very strong and 'E' significant weaknesses. 


\section{The relatively slow progress made in addressing legacy related NPLs reflects a} host of factors, including a weak credit culture and weak creditor rights. These include: (i) a nonsupportive legal and judicial framework that makes the restructuring and foreclosure process cumbersome and costly; ${ }^{8}$ (ii) tax disincentives for prompt recognition of losses through write offs; ${ }^{9}$ and (iii) until recently, gaps in the regulatory treatment of restructured loans. In the mission's opinion the slow progress in addressing NPLs may also reflect the political clout family-owned corporates enjoy in the Thailand political system. This may explain difficulties creditors have faced in converting debt into equity, the relatively modest change in ownership of companies, and the failed attempts to address shortcomings in the Bankruptcy Act and Civil Procedure Code. The result of this legislative stalemate is to reduce the value of NPLs, which in turn has discouraged banks from selling them at the market-determined value, and weakens the credit culture in Thailand. Protracted bankruptcy also reduces the economic value and efficiency as large assets remain out of the productive system or, in some cases, distort corporate competition.

\section{There are several actions, some of which the BOT is already implementing, that could both address the current overhang of NPAs and reduce the likelihood of a recurrence of this problem in the future.}

- $\quad$ The BOT's decision to have banks fully implement IAS 39 will bring more clarity and veracity to their balance sheet, which in turn will encourage banks to deal promptly with problem loans.

- $\quad$ The BOT should strengthen its supervisory program of holding bank management fully accountable for identifying distressed assets and criticize management of those banks who continue to rely on bank supervisors to uncover their banks' problem loans.

- $\quad$ The BOT should maintain its policy of requiring banks to adopt more conservative guidelines on restructured loans, notably by requiring restructured loans to perform for at least three payment periods before reclassifying the loan as performing. This will reduce the likelihood of multiple restructuring of the same loan.

\footnotetext{
${ }^{8}$ The FSAP team identified a number of weaknesses. Among them: a balance sheet test used to determine solvency rather than a liquidity test (i.e., ability to service debt), which is the preferred test; rehabilitation provisions applying to large creditors with debt of more than Baht 10 million; banks having to participate in a public auction to acquire the pledged asset; and the special court established by the central bankruptcy court overburdened by a backlog of cases and inadequately resourced.

${ }^{9}$ Tax regulations require the application of strict and time consuming tests to ensure that banks have exhausted all possible avenues for realizing the underlying assets before utilizing the tax deduction on losses.
} 
- The government should, as a matter of high priority, further strengthen creditors rights by expediting the foreclosure processes, enhancing the effectiveness of the specialized bankruptcy court, and adopting a liquidity test to better reflect the true financial position of troubled debtors.

- The government should reform tax regulations to permit prompt recognition of losses by making it easier to deduct provisions or write offs for tax purposes.

\section{The government should require that state-owned AMCs accelerate the pace of} distressed asset disposal. While fiscal risks have largely been mitigated, the protracted warehousing of large amounts of distressed assets among state-owned AMCs is costly. It sends the wrong message to the marketplace and reduces the likelihood for the development of a market for distressed assets. The government's continued involvement in purchasing NPAs from banks reduces banks' incentive to resolve the NPL problem through market-based solutions. More aggressive but objective benchmarks (possibly time-bound) and realistic guidelines for AMC managers should be set that explicitly acknowledge that market prices may be below the valuation assigned to the asset being sold (i.e., state-owned AMC managers should be given relief from the paralyzing attitude of avoiding any loss in the disposal of assets). Finally, a realistic exit strategy should be developed for these AMCs. ${ }^{10}$

\section{The government should also continue its divestiture program of its equity stakes} in commercial banks that were recapitalized during the crisis. Virtually all of these mixed-ownership commercial banks were private sector banks that the government took an equity stake in for the purpose of restoring banking stability. These equity investments were expected to be temporary. When the government is an owner of a bank, it creates the potential for the government to affect lending decisions and puts the bank supervisor in the position of, in effect, supervising activities sanctioned by the government. This is particularly awkward where operational independence of the supervisor is not explicitly provided in the law, as is the case in Thailand. Further, the noncompetitive award of government business to state-owned banks may lead to market distortions and creates the appearance of an uneven playing field. The mission recommends that the government develop and implement an exit strategy from its ownership of commercial banks. Consistent with the development of an efficient and competitive banking system, the government should also assure that stateowned banks including Krung Thailand Bank (KTB), which has been owned by the government for a number of years, is also subject to the same regulatory treatment regarding external auditors as private banks and that the bank is insulated from potential political

\footnotetext{
${ }^{10}$ The closure of Financial Institutions Development Fund (FIDF) — the owner of the state-owned AMCs- has been postponed from 2009 to 2013. Thailand Asset Management Corporation (TAMC), by law, is to wind down its operations by end-2011. There are no such clauses for the Sukhumvit Asset Management Co, Ltd and Bangkok Commercial Asset Management Co, Ltd.
} 
interference through the establishment of a proper governance structure and enhanced disclosure requirements. Over time, consideration could be given to fully privatizing stateowned banks.

\section{Stress test results}

17. Several stress tests for the banking sector were carried out by the BOT, the mission, and the eight largest Thailand commercial banks. These eight banks accounted for 88 percent of the Thailand banking system assets at end-2006 and covered all systemically important financial institutions. ${ }^{11}$ The stress tests involved single factor stress tests and macroeconomic scenario analysis — both a global and domestic stress event (Appendix II).

18. While the stress tests indicated that the Thailand banking system was resilient to a variety of macroeconomic and factor specific shocks, they underscored the need for continued close supervisory attention by the BOT, in particular of the weaker banks in the system. The BOT had identified these weaker banks through its ongoing supervisory process and some of them are currently in the process of recapitalization.

- As a result of Thailand banks' large loan book-loans account for about half of banking assets, with the bulk extended to corporates - credit risk is by far their main source of vulnerability. The four largest banks weather the macro shocks in the stress test comparatively better than the smaller banks, and private banks perform comparatively better than state-owned banks. Under the two shock scenarios, NPLs as percent of total loans would approximately double over a two-year horizon. Banks accounting for about one-fifth of total banking assets would fall below BOT's minimum CAR. The stress scenarios are extreme but plausible shocks

- $\quad$ Liquidity risk was found to be material for a few banks notwithstanding the current high liquidity in the banking system.

- Interest rate risks on the banking book were contained, with only one small bank reporting a significant impact in terms of regulatory capital. However, it is important to note that the tests did not highlight any common pattern of behavior across banks. Instead, a variety of impacts emerged reflecting the different positions and maturity structures across financial institutions.

\footnotetext{
${ }^{11}$ Stress tests for banks' exposure to the housing market and for some of the larger deposit-taking SFIs, such as the Government Housing Bank, could not be conducted due to the lack of sufficient supervisory financial information for the SFIs. Although SFIs overall do not account for a material proportion of the assets and risks to the banking system, it would have been desirable to have included the two largest deposit taking SFIs given their dominant role in the mortgage market.
} 
- Market risks were found to have a minor impact. This reflects the small size of banks' trading portfolios, regulatory limits on banks' exposure to securities, prudential rules governing open foreign exchange positions, the very small proprietary trading positions, and the use of "plain vanilla" interest rate and forex hedging instruments.

- $\quad$ Contagion risks through the interbank market and international market were negligible due to the very small size of the interbank exposures and because Thailand banks have reduced their balance sheet exposure to international credit markets since the 1997 crisis, in particular by significantly lowering their short term external debt exposure. Thailand banks rely mainly on retail deposits for funding.

\section{Nonbank financial institutions and capital markets}

19. Nonbank financial institutions - in particular contractual savings institutionsare growing in size, although their role in the financial system remains small. The insurance sector is in the mid-development stage and profitable. Insurance penetration (total premium to GDP) stood at 3.6 percent and insurance density (total premium per capita) was US\$99. The sector, measured by premium, is the largest among the members of the Association of South-East Asian Nations (ASEAN). The FSAP team found the sector to be sound and profitable, but recommended a strengthening of the regulatory framework. The pension/provident fund industry is small, reflecting in part the lack of a mandatory social security system. Mutual funds have grown rapidly since 2004, with 724 funds managing about B 1.14 billion in net asset value at end March 2007. Fixed income funds account for the bulk of net asset value, with most effectively short-term money market funds.

The brokerage industry is relatively small, not well capitalized, faces entry restrictions, and has performed generally poorly in contributing to market development. Brokerage firms are not active traders in the capital markets, limit their underwriting services to equity, and rely heavily on retail driven sales at fixed commission fees for revenue.

\section{While Thailand's capital markets are relatively large in size, market development suffers from limited issuance activity and shallow secondary markets.}

- $\quad$ The Thailand bond market is large but, in common with many countries, dominated by public debt instruments, with corporate debt issuance activity limited. While the primary market for government securities functions relatively well, liquidity in the secondary market is poor. Addressing the fragmentation of the current stock of public debt, strengthening the role of primary dealers as market makers as well as improving public debt management (including reducing frequency of auctions while increasing the size of individual offerings), could help promote secondary market liquidity. 
- $\quad$ Thailand equity markets have grown significantly in the past 10 years, with total market capitalization equivalent to 75 percent of GDP at end-2006. However, the SET is characterized by: (i) heavy concentration, with the ten largest companies accounting for 40 percent of the total market capitalization and the government also owning a substantial portion of the largest companies; (ii) high volatility, reflecting also the small volume of freely floating shares; (iii) retail driven, with retail investors accounting for over half of daily market turnover; and (iv) low valuation, with priceto-earnings ratio of less than 10 , much lower than most exchanges in the region. A number of measures could further promote deeper equity markets, including the government renewing its commitment to privatization, liberalizing entry restrictions into the brokerage industry, and eliminating the SET regulation that mandates fixed brokerage commissions.

\section{REGULATORY AND SUPERVISORY FRAMEWORK}

21. While the regulatory and supervisory program for banking in Thailand reflects a high degree of compliance with international standards, its effectiveness is threatened by an outdated legal framework and absence of formal legal independence. The current law holds the potential for compromising the authority of BOT as bank regulator. Responsibility for banking supervision is shared between the MOF and the BOT and the BOT formally lacks full and independent enforcement capabilities. The mission, however, found no evidence of the MOF interfering in the supervisory operations of the BOT. Nonetheless, the legal subordination of BOT to the MOF has the potential to lead to interference or delay in taking required regulatory action and delays in operational supervisory decisions.

\section{The BOT has worked around these legal weaknesses, although there are risks} associated with this strategy. The MOF could, in theory, overrule the BOT's regulatory decisions. The BOT's regulatory powers could further be challenged in court and overruled. Also, corrective measures that lack explicit legal underpinnings may more easily be revoked. Overall, this creates an environment of legal uncertainty, which can - among other thingshurt banking sector product innovation and soundness, and limit the range of remedial actions available to the BOT to deal with noncompliance. This underscores the need to expeditiously pass and implement pending draft laws, which would address a number of these shortcomings.

\section{Aligning Thailand's financial supervisory framework with international best} practices requires providing greater independence to all of the supervisors. The heads of the BOT and other supervisory bodies, more broadly, perform functions that are critically important to assuring financial stability and soundness. At all times, they must feel sufficiently secure to take necessary measures to address problems, even if these actions are politically unpopular or involve enforcement actions against government officials who sit on 
the boards of banks. The current laws should be amended to include appropriate procedures for appointment and dismissal of the heads of regulatory bodies so that:

- $\quad$ the supervisory agencies have the necessary legal powers to fully meet their mandate to preserve the soundness and stability of the financial system;

- the heads of the supervisory agencies are appointed for significant fixed terms and on the basis of their qualification and integrity; and

- $\quad$ there are objective safeguards regarding their dismissal—with conditions for dismissal explicitly stated in the law. On the rare occasions on which the governor or the head of another supervisory body is to be dismissed, the reasons for doing so should be clear and publicly disclosed.

\section{The BOT also should be given legal powers to conduct consolidated banking} supervision. Given the emergence of large banking conglomerates in Thailand, with significant ownership of nonbank financial institutions and considerable market share, consolidated supervision has become an important instrument for the BOT in promoting the stability of the overall financial system. Currently, the BOT does not have any legal authority to perform consolidated supervision of banks' exposure to their insurance or securities businesses. To overcome this problem, the BOT has used a combination of moral suasion and the use of contractual conditions, such as imposing certain conditions when banks apply for permits and licenses to perform its supervisory responsibilities. However, undue risk exposures could arise for banks in their universal banking activities, in particular if those segments are not well regulated, and coordination among the regulating agencies is not well developed.

\section{The BOT, as bank regulator, should also distance itself from the functions of} management and ownership in the intervened banks (via its ownership of the FIDF. Although the FIDF is an independent juristic entity, and the MOF has assumed the FIDF's liabilities, in practice, the FIDF is run within the organizational framework of the BOT and managed by a board chaired by the Governor and staffed by both the BOT and MOF. This puts the BOT in a situation where it is required to supervise the banks with whose ownership and management function it is involved. This arrangement creates, at the minimum, the appearance of a conflict of interest for the BOT as both an owner and bank supervisor.

\section{The current supervisory framework of deposit-taking SFIs should also be} strengthened. Loan performance at SFIs, as measured by the level of outstanding NPLs compared to total loans, is weak, with potential fiscal implications. The deposit-taking SFIs, which in practice, operate alongside commercial banks, are regulated under separate, SFIspecific laws. Having a different regulatory regime for SFIs and according the SFIs special privileges can contribute to level-playing-field concerns and distort competition. While the 
MOF has delegated authority to the BOT to examine the SFIs on an annual basis, the overall supervision of these deposit-taking SFIs remains with the MOF. If, going forward, the SFIs continue to operate as major deposit-taking institutions, they should be supervised in the same manner as commercial banks. The current bifurcated approach to examination and supervision of SFIs creates a potential source of reputation risk for both the BOT and the MOF.

27. The shortcomings in the regulatory and supervisory framework governing the insurance sector are well understood and the authorities are beginning to address them. The key reforms are: to amend the insurance law to establish the insurance supervisor as an independent authority; move toward risk-based capital and supervision; and introduce a policyholder protection scheme. A comprehensive stress test should also be undertaken to assess the sector's vulnerabilities. Once implemented, these reforms would provide the sector with a sounder platform to support the expected continued growth.

28. While the regulatory framework for capital markets is fundamentally sound, the regulatory independence of the SEC should be strengthened and the SEC should be empowered to use civil proceedings to enforce the law. Under the current Securities Exchange Act (SEA), the MOF has the formal authority to supervise the SEC, even though the powers under SEA have never been invoked by any Minister. Furthermore, the MOF has been assigned the formal licensing responsibilities for securities firms and mutual fund operators. These are not in line with international standards. The SEA should also be amended to empower the SEC to independently bring civil proceedings when securities laws are violated, and the legal definition of insider trading should be clarified.

29. With financial markets in Thailand becoming more integrated and complex, there is a need to coordinate and communicate more effectively among the different regulators and with market participants. Overall, the mission is of the view that the current institutional arrangement with different regulatory bodies is adequate. The costs associated with creation of an integrated regulator would appear to outweigh any possible benefits. Instead, along with strengthening regulators' legal power and the creation of a separate insurance regulator, the focus should be on improving coordination among the various regulators and industry participants. Coordination promotes sound financial sector policies and regulations. Events in one market can quickly spill over to other markets and policies intended to address a problem in one particular sector could have unintended consequences on other markets. A number of committees for consultation exist and Memorandums of Understanding (MOU) have been formalized among the various regulatory bodies. The mission believes, nonetheless, that there is a need for more regular, frequent and open consultations and discussions among regulators and, as appropriate, the MOF at the staff level. This should include early consultations in the drafting stage of critical reforms. There is also a need for more effective dialogue and consultations with the industry as policies are being developed. 


\section{Crisis Management, Bank Resolution, ANd SAFety Net}

\section{The BOT has in place a sound crisis management framework to facilitate} prompt and coordinated action in the face of a crisis. A contingency plan has been prepared to deal with a systemic banking crisis and a continuity plan for disaster events. Guidance has been issued to banks to prepare their own disaster recovery plans and business continuity plans. A crisis management committee (CMC) chaired by the BOT Governor is designated to act as the central command to coordinate and manage banking crisis resolution. ${ }^{12}$ The BOT has established transparent guidelines governing the use of emergency credit to lend to banks perceived as solvent but illiquid. A working group has also been set up to arrange scenarios for testing once every year and to provide feedback to make improvements in the contingency plans.

\section{There is room, however, to strengthen the current bank resolution framework} by moving toward a more transparent and well-defined process for addressing troubled financial institutions. Several critical bank resolution decisions remain under the purview of the MOF. The MOF is in charge of granting, suspending and revoking licenses, approving mergers and acquisitions, deciding on conservatorship, and liquidating problem assets. A number of other supervisory activities require joint decisions between the MOF and the BOT, such as establishing minimum capital adequacy or suspending a bank's operations. In a number of supervisory activities that are critical to ensuring banking stability, the BOT must first make a recommendation to the MOF and await its approval (e.g., increase in a troubled bank's capital funds or removal of directors or executive officers). This sharing of regulatory enforcement powers with the MOF can result in delays in supervisory decisions. In this context, the mission urges the authorities to implement the recently designed prompt preventive action (PPA) and prompt corrective action (PCA) framework by the BOT. The PPA and PCA include many effective bank resolution elements including corrective actions to address liquidity problems and undercapitalization in various stages, clearly defined trigger points, and a corresponding set of measures that need to be taken to prevent undue delays. The PCA is awaiting MOF's approval. For actions in which taxpayers' money might be needed such as providing financial assistance to resolve troubled banks, the MOF needs to be fully involved in the decision-making process.

\section{The authorities recognize that there are moral hazard problems associated with} the current financial safety net arrangement. Thailand remains the only East Asian crisis country that has not yet formally removed its blanket deposit guarantee. Its continuation runs the risk of eliminating market discipline and facilitating weaker banks attracting deposits in

\footnotetext{
${ }^{12}$ For instance, when the CMC deems it necessary for the FIDF to support problem banks, CMC notifies FIDF to lend to the problem bank (against collateral) or participate in a capital increase.
} 
direct competition with healthier banks. The mission supports the authorities' intention to put in place a limited deposit protection scheme. It urges that the design of the new scheme include enhanced bank resolution tools providing for early resolutions of troubled banks, and mandate minimizing costs related to providing support to uninsured depositors.

\section{FinANCIAL MARKet InTEGRITY}

\section{The BOT has available a range of powers and instruments for effective systemic} liquidity management. The BOT has full autonomy on how it uses its own instruments. The BOT is also closing its repurchase (RP) window to promote more active use of the interbank market for liquidity management. There are, however, a few legal shortcomings that could potentially limit the BOT's ability to manage systemic liquidity. These are being addressed under the proposed amendments to the BOT Act. Passage of the amendments would permit the BOT to pay interest on banks' uncollateralized deposits held with the central bank, which it currently cannot do. It would also remove the need for the BOT to receive approval by the MOF on the overall ceiling for the amount of BOT bills/bonds that can be issued for monetary purposes.

\section{The assessment of BOT's Automated High-Value Transfer Network} (BAHTNET) shows that while the overall payment system is well developed and governed, the system is exposed to systemic risks. The finality of the settlement of interbank transactions can be challenged in the event of bankruptcy. Furthermore, the SEC and the TSD do not have presently the authority to respond promptly to financial failures by market participants. The mission recommends that these two shortcomings be addressed quickly.

35. The current AML/CFT framework needs to be brought in line with the requirements of the Financial Action Task Force (FATF) 40+9 Recommendations. While the Thailand AML/CFT regime has resulted in a very large number of suspicious transaction reports, a large amount of seized assets, and has contributed to the Thailand government's objective of tackling drug crime, the legal and institutional framework is not fully in line with international standards and codes. There are weaknesses in the legal framework, in the pursuit of money laundering cases, coverage of institutions, and enforcement which should be addressed. The AMLA should be amended inter alia to: (i) properly criminalize all serious predicate money laundering offenses; (ii) provide for more comprehensive coverage of financial institutions; and (iii) clearly delineate the roles of Antimoney Laundering Office (AMLO) and the financial sector supervisors for monitoring compliance and provide appropriate powers for conducting compliance examinations. Financial institutions should be required to develop internal policies, procedures and controls for AML/CFT. 


\section{Annex: ObServance of Financial Sector Standards ANd CODES-Summary} ASSESSMENTS

The annex contains summary assessments of five international standards relevant for the financial sector. The assessments were undertaken in the context of the FSAP during 2007 and have helped to identify the extent to which the supervisory and regulatory framework is adequate to address the potential risks in the financial system in Thailand.

The following detailed assessments of financial sector standards were undertaken:

- $\quad$ The Basel Core Principles for Effective Banking Supervision (BCP), by Aditya Narain (IMF, MCM) and Göran Lind (external expert);

- $\quad$ The International Organization of Securities Commission (IOSCO) Objectives and Principles for Securities Regulation, by Jonathan Katz (external expert);

- $\quad$ The Transparency in Monetary Policy (MPT) by Jeanne Gobat (IMF, MCM);

- The Principles for Systemically Important Payment Systems (CPSS) and the Recommendations for Securities Settlement Systems (RSSS), by Elias Kazarian (IMF, MCM); and

- $\quad$ The AML and CFT, by Steve Dawe (IMF, LEG).

\section{A. Assessment of Compliance with the Basel Core Principles for Effective Banking Supervision}

36. The framework for banking supervision has been considerably strengthened since the crisis of the last decade. The BOT has a cadre of competent and well trained supervisory staff and has issued a comprehensive set of prudential regulations as well as guidance on risk management based on international best practices. A system of risk-based supervision is in place, which employs well documented and implemented on-and off-site techniques to focus on key risks in banks. The enabling legal framework for effective banking supervision is, however, a matter of concern as the MOF and not the BOT has been empowered by the law to take action on several routine aspects of supervision. While in practice, this may not have been a major impediment, the laws need to be amended to provide BOT the required operational independence to perform its supervisory functions. Another major gap is in the supervision and regulation of the state-owned deposit taking SFIs, which function as commercial banks but are not under the same supervisory regime as banks. The authorities are aware of these issues. Expediting passage of laws and amendments aimed at addressing them will go along way in improving compliance with the BCP.

\section{Introduction}

37. This assessment of the BCP in Thailand has been completed as part of the FSAP undertaken jointly by the World Bank and the IMF mission, which visited Bangkok during January 16-31, 2007. The assessment was carried out by Göran Lind of the Sveriges Riksbank and Aditya Narain of the IMF. It reflects the position of compliance of banking supervision practices of the Thailand authorities as of the end of January 2007. 


\section{Information and methodology used for assessment}

38. Consistent with the October 2006 Basel Committee guidance and the timing of this assessment, the mission used the 1997 version of the BCPs and the 1999 version of the assessment methodology. ${ }^{13}$ It is based on a self-assessment of compliance prepared by the BOT, a review by the assessors of English translations of laws, regulations, and other documentation, as well as detailed interviews. The mission is grateful to the BOT for providing all of the information and documents required by the assessors and for arranging meetings with industry representatives and other agencies. The high degree of preparation and the methodical documentation provided has considerably facilitated the work of the mission. The mission met with officials of the BOT, the Fiscal Policy Office (FPO) of the MOF, the SEC and the Department of Insurance (DOI), and representatives of the banks, banking associations; accounting, legal and other financial services professionals.

\section{Institutional and macro prudential setting, and market structure-Overview}

39. The macroeconomic policy environment in Thailand has improved since the crisis of 1997, following the establishment of a new macro policy framework including inflation targeting, a managed floating exchange regime, and the implementation of a fiscal sustainability framework.

40. The banking sector is the mainstay of the financial system. Commercial banks account for almost 62 percent of financial sector assets at end-2006; the top five commercial banks account for about 61 percent of banking assets and 65 percent of deposits. The stock and bond markets have market capitalization at 72 percent of GDP and 44 percent, respectively. The insurance, provident fund and mutual fund sectors are growing, although from a small base. The structure of the banking sector has changed markedly since the 1997 financial crisis, with the number of deposit-taking institutions declining sharply from 135 at end-1996 to 50 at end-2006, with most of the consolidation taking place among finance companies. Foreign-owned banks play an important role but their contribution is restricted.

\section{The government's role as shareholder in financial institutions has increased} sharply over the past decade, largely because of intervention during the financial crisis. The government has controlling stakes in three banks and significant shares in three others. There are several SFIs, four of which take public deposits and operate in competition with

\footnotetext{
${ }^{13}$ Basel Committee suggested that October 2006 principles not apply to countries such as Thailand that had already committed to and completed their BCP self-assessment.
} 
commercial banks, but are regulated under separate, SFI-specific laws. Level playing field issues arise due to state ownership of banks.

\section{Banking fundamentals continue to strengthen, with most Thailand banks} reporting high capital levels and solid profitability. The average capital-to-risk weighted assets ratio for Thailand banks was 14 percent at end-2006, well above the regulatory minimum. Banks' profitability, which had strengthened considerably since 2004, fell in the fourth quarter of 2006 due to the large provisioning requirements arising as a result of the introduction of IAS 39. The resolution of troubled assets continues to be a key concern with a gross NPL ratio about 7.5 percent (loan loss coverage ratio at 70 percent as of end-2006 and the average rate of reentry of restructured loans into the NPL category of 14 percent.

\section{Preconditions for effective banking supervision}

43. Thailand has a civil law system under which the courts decide cases by applying or interpreting statutory provisions. In some cases the existing laws have been overtaken by developments in the financial sector. New legislation for banking and banking supervision, notably the FIBA, the amended BOT Act, and a DPA, are in the legislative process but none have yet been passed.

\section{There has been a marked improvement in the overall credit environment.}

Credit rating and scoring systems have been developed in banks and a credit bureau now provides its services to both banks and nonbanks. The Bankruptcy Act and the Civil Procedure Code, which entails foreclosure procedures for civil cases, have been amended and a Bankruptcy Court and a Bankruptcy Case Procedure Act enacted. However, progress in resolution of the legacy NPAs still remains slow, due both to the prolonged processes required to possess the collateral and the "wait and watch" attitude of banks and AMCs looking towards a recovery in the property markets.

\section{BOT has taken many steps to develop a crisis management framework to} facilitate prompt and coordinated action in the face of a crisis. A contingency plan has been prepared to deal with systemic banking crisis and a continuity plan for disaster events and guidance has also been issued to banks in this regard. A crisis management committee chaired by the BOT Governor is designated to coordinate and manage crisis resolution. A working group has also been set up to arrange scenarios for testing once every year.

\section{Main findings}

46. Objectives, autonomy, powers, and resources (CP 1). Responsibility for banking supervision is shared between MOF and BOT. For some supervisory activities BOT may act on its own, but in many cases it must first make a recommendation to MOF and await its 
approval. Currently, MOF has delegated to BOT the ability to conduct offsite monitoring and onsite examinations of commercial banks and SFIs.

47. There are shortcomings in the present legislation that hinder effective supervision. BOT attempts to compensate for this by attaching contractual conditions when banks apply for permits. While this has often worked well in practice, the lack of explicit legal powers makes supervision less effective.

48. Licensing and structure (CPs 2-5). In addition to commercial banks and retail banks, some state-owned SFIs, may receive deposits in accordance with the special Acts under which they are established. The SFIs are regulated and supervised by MOF, although MOF has currently delegated the right to conduct examinations to BOT. The separate SFI Acts also set out rules for the corporate governance and audit of the SFIs, which are partly different from the corresponding rules for commercial banks.

49. Prudential regulations and requirements (CPs 6-15). The regulations and policies on capital adequacy are in line with the Basel Capital Accord of 1988, with a few exceptions. Reduced risk-weights for calculating capital charges have recently been introduced for loans collateralized by residential real estate and for small retail loans. Although the effect on banks' capital of these changes is currently insignificant, since the remaining parts of the new framework will be applied only after December 2008, this could, in principle, weaken the capital adequacy regime in the interim period.

50. BOT has issued detailed guidance on risk management for banks, and has generally integrated these well in its supervisory framework. The classification system of NPLs is based on both qualitative and quantitative criteria. However, the level of restructured loans, and the proportion of these that result in NPLs continue to be high in some banks. Country risk management guidance has been issued recently and banks are still in the process of implementing the required framework and devising related risk rating and provisioning systems.

51. The framework for managing operational risk encompasses losses arising from fraud, and components of AML/CFT have been reinforced through onsite examination, although comprehensive supervisory guidelines in this regard have only recently been issued and the MOU for information sharing between BOT and AMLO just signed.

52. Methods of ongoing supervision (CPs 16-20). BOT follows a system of continuous supervision that uses both onsite examination and offsite monitoring based on the assessment of key risks. Currently, the BOT does not have adequate legal authority to call for information from banks on a consolidated basis, or from entities related to banks. It also requires MOF approval to introduce any periodic reporting requirements, and the authority to 
examine banks has been delegated to it by the MOF under the Act. While this has not hindered BOT supervision currently, this can be an impediment in the future.

53. Information requirement (CP 21). Banks in Thailand are subject to accounting and auditing standards that have been broadly accepted internationally. The local accounting standard conforms generally with the IAS, with some exceptions. For instance, IAS 39 is currently being implemented on a gradual basis, which includes stricter rules for loan-loss provisioning. The appointment of external auditors for each bank must be approved by BOT on a yearly basis. Before each audit, the external auditor submits and discusses the scope of the audit with BOT. According to the law, external auditors must report any material findings to the bank's Board and to BOT and also provide special reports to BOT on effectiveness in internal audit and instances of related lending.

54. Formal powers of supervisors (CP 22). Laws and regulations provide a wide range of remedial powers to $\mathrm{MOF} / \mathrm{BOT}$. However, in cases where BOT has to wait for MOF approval of proposed corrective actions timeliness and effectiveness might be impaired. BOT has recently proposed to issue a more structured policy framework for taking PCA against under-capitalized banks.

55. Cross-border banking (CPs 23-25). Although overseas assets of Thailand banks are only about 7 percent of total assets, some banks have become more active internationally and BOT has recently begun conducting onsite inspections of major overseas operations. MOUs for information-sharing with foreign supervisory authorities have also been concluded in a few cases.

\section{Table 5. Thailand: Summary Compliance with the BCP-Report on the Observance of Standards and Codes (ROSCs)}

\begin{tabular}{|l|l|}
\hline \multicolumn{1}{|c|}{ Core Principle } & \multicolumn{1}{c|}{ Comment } \\
\hline $\begin{array}{l}\text { 1. Objectives, autonomy, } \\
\text { powers, and resources }\end{array}$ & $\begin{array}{l}\text { While BOT has adequate and skilled resources to carry out its supervisory } \\
\text { responsibilities, its objectives, autonomy, and legal authority is considerably } \\
\text { affected by deficiencies in the legal framework for banking supervision. Draft } \\
\text { amendments in the pipeline, when enacted as drafted, should substantially } \\
\text { improve compliance. }\end{array}$ \\
\hline 1.1 Objectives & $\begin{array}{l}\text { While the laws clearly set out the mandates of the MOF and BOT, there is in } \\
\text { practice a mix of roles. The Minister has delegated large parts of supervision to } \\
\text { BOT, but not the corresponding powers to take corrective action against } \\
\text { problems in banks, or to set legally binding regulations in all areas without } \\
\text { Ministerial approval. }\end{array}$ \\
\hline 1.2 Independence & $\begin{array}{l}\text { The Minister is by law the ultimate decision-maker for many issues pertaining to } \\
\text { the conduct of supervision. Though in practice the Minister has approved actions } \\
\text { recommended by BOT, nevertheless, the legal primacy given to the Minister can } \\
\text { allow for interference and delays in operational supervisory decisions. }\end{array}$ \\
\hline 1.3 Legal framework & The legal support for BOT supervision is currently not explicit to some extent. \\
\hline
\end{tabular}




\begin{tabular}{|c|c|}
\hline & $\begin{array}{l}\text { This has forced BOT to rely on other arrangements such as moral suasion or } \\
\text { conditional approvals. }\end{array}$ \\
\hline 1.4 Enforcement powers & $\begin{array}{l}\text { BOT does not have the legal authority in several cases, to take enforcement } \\
\text { action without approval of the Minister. }\end{array}$ \\
\hline 1.5 Legal protection & Meets the essential criteria. \\
\hline 1.6 Information sharing & Meets the essential criteria \\
\hline 2. Permissible activities & $\begin{array}{l}\text { Some of the SFIs, which represent a fifth of public deposits and act as } \\
\text { commercial banks, are not formally subject to the same supervisory regime in } \\
\text { many respects. MOF has delegated their examination to the BOT, but the MOF is } \\
\text { not bound to act on BOT advice. }\end{array}$ \\
\hline 3. Licensing criteria & Meets the essential criteria. \\
\hline 4. Ownership & Meets the essential criteria. \\
\hline 5. Investment criteria & Meets the essential criteria. \\
\hline 6. Capital adequacy & $\begin{array}{l}\text { Compliant with Basel I with the exception of recently reduced risk weights for } \\
\text { residential mortgages and lending to small business. }\end{array}$ \\
\hline 7. Credit policies & Meets the essential criteria. \\
\hline $\begin{array}{l}\text { 8. Loan evaluation and loan- } \\
\text { loss provisioning }\end{array}$ & Meets the essential criteria. \\
\hline 9. Large exposure limits & Meets the essential criteria. \\
\hline 10. Connected lending & $\begin{array}{l}\text { Meets the essential criteria. Though the law does not provide explicit authority to } \\
\text { interpret the definition of related and connected parties on a case by case basis, } \\
\text { BOT has used its general supervisory authority to do so in cases in the past. }\end{array}$ \\
\hline 11. Country risk & $\begin{array}{l}\text { Guidelines on country risk management have been introduced in July } 2006 \text { and } \\
\text { banks are in the process of implementation. }\end{array}$ \\
\hline 12. Market risks & Meets the essential criteria. \\
\hline 13. Other risks & Meets the essential criteria. \\
\hline 14. Internal control and audit & Meets the essential criteria. \\
\hline 15. Money laundering & $\begin{array}{l}\text { Although examiners have been looking at abuse of the financial system including } \\
\text { some aspects of AML for some time now, comprehensive guidance with regard } \\
\text { to AML has been issued recently. }\end{array}$ \\
\hline $\begin{array}{l}\text { 16. Onsite and offsite } \\
\text { supervision }\end{array}$ & Meets the essential criteria. \\
\hline 17. Bank management contact & Meets the essential criteria. \\
\hline 18. Offsite supervision & $\begin{array}{l}\text { BOT has developed a skilled and comprehensive offsite supervision function } \\
\text { even though it lacks the legal ability to prescribe reports on a consolidated basis } \\
\text { or the ability to prescribe any periodic reports without MOF approval. }\end{array}$ \\
\hline $\begin{array}{l}\text { 19. Validation of supervisory } \\
\text { information }\end{array}$ & $\begin{array}{l}\text { Meets the essential criteria. BOT engages with the external auditors, approves } \\
\text { their appointment and work program except in the case of the state-owned banks } \\
\text { which are audited by the Office of the Auditor General (OAG). }\end{array}$ \\
\hline 20. Consolidated supervision & $\begin{array}{l}\text { In the absence of explicit legal ability to conduct consolidated supervision, BOT } \\
\text { has had to resort to moral suasion and sanction to do so. }\end{array}$ \\
\hline 21. Accounting standards & Meets the essential criteria. \\
\hline 22. Remedial measures & $\begin{array}{l}\text { While a range of corrective action is available, in many cases BOT requires } \\
\text { approval of the Minister for taking remedial measures, which may delay action } \\
\text { and dilute prudential considerations }\end{array}$ \\
\hline $\begin{array}{l}\text { 23. Globally consolidated } \\
\text { supervision }\end{array}$ & $\begin{array}{l}\text { Meets the essential criteria. BOT has recently implemented a program of onsite } \\
\text { visits of overseas operations of local banks to supplement monitoring through the } \\
\text { parent. }\end{array}$ \\
\hline 24. Host country supervision & $\begin{array}{l}\text { Meets the essential criteria. While informal contacts have mainly been the basis } \\
\text { for cooperation with overseas supervisors, MOUs have been entered in to with a }\end{array}$ \\
\hline
\end{tabular}




\begin{tabular}{l|l}
\hline $\begin{array}{l}\text { 25. Supervision over foreign } \\
\text { banks' establishments }\end{array}$ & few foreign counterparts. \\
\hline
\end{tabular}

\section{Table 6. Thailand: Recommended Action Plan to Improve Compliance with the Basel} Core Principles

\begin{tabular}{|c|c|}
\hline Reference Principle & Recommended Action \\
\hline $\begin{array}{l}\text { 1. Objectives, autonomy, } \\
\text { powers, and resources }\end{array}$ & $\begin{array}{l}\text { BOT to be given legal authority to issue regulation, conduct supervision, and } \\
\text { take enforcement actions without requiring approval of the Minister. }\end{array}$ \\
\hline 2. Permissible activities & $\begin{array}{l}\text { Amend laws to enable SFIs which continue to take public deposits to be } \\
\text { regulated and supervised as banks by BOT. }\end{array}$ \\
\hline 6. Capital adequacy & $\begin{array}{l}\text { Ensure banking system and individual banks maintain adequate capital during } \\
\text { transition to Basel II especially in light of the recent reduction in some risk } \\
\text { weights. }\end{array}$ \\
\hline $\begin{array}{l}\text { 8. Loan evaluation and loan- } \\
\text { loss provisioning }\end{array}$ & $\begin{array}{l}\text { Review and strengthen regulations on loan restructuring to prevent high rate of } \\
\text { reentry of restructured loans to nonperforming status. }\end{array}$ \\
\hline $\begin{array}{l}9 \& 10 . \text { Large exposures and } \\
\text { related and connected lending }\end{array}$ & $\begin{array}{l}\text { An explicit legal authority to interpret the definition of related and connected } \\
\text { parties will facilitate the BOT in identifying any exposures created through } \\
\text { complex nominee structures. }\end{array}$ \\
\hline 11. Country risk & $\begin{array}{l}\text { Fully implement July } 2006 \text { country risk guidelines for direct and indirect } \\
\text { exposures for banks with material exposures. }\end{array}$ \\
\hline 15. Money laundering & $\begin{array}{l}\text { Follow up implementation of } 2007 \text { guidelines on AML/CFT and operationalize } \\
\text { information sharing with AMLO according to the MOU. }\end{array}$ \\
\hline 18. Offsite supervision & $\begin{array}{l}\text { BOT to obtain legal powers to call for reports from banks without approval of } \\
\text { MOF and to call for reports on consolidated basis. }\end{array}$ \\
\hline $\begin{array}{l}\text { 19. Validation of supervisory } \\
\text { information }\end{array}$ & $\begin{array}{l}\text { External auditors of all banks should be subject to same supervisory } \\
\text { requirements including approval. Audit by independent external auditors } \\
\text { should supplement any OAG audit. }\end{array}$ \\
\hline 20. Consolidated supervision & $\begin{array}{l}\text { BOT to have legal authority to conduct consolidated supervision in all its } \\
\text { aspects without MOF approval. }\end{array}$ \\
\hline 21. Accounting standards & $\begin{array}{l}\text { External auditors to be required to report all material findings to the Board and } \\
\text { BOT immediately instead of within } 90 \text { days as at present. }\end{array}$ \\
\hline 22. Remedial measures & $\begin{array}{l}\text { BOT should have the legal authority to take a broad range of corrective actions } \\
\text { without MOF approval. }\end{array}$ \\
\hline 24. Host country supervision & $\begin{array}{l}\text { To supplement informal contacts, BOT should continue to pursue MOUs with } \\
\text { other home / host supervisors significant for their banks/system. }\end{array}$ \\
\hline
\end{tabular}

\section{Authorities' response}

56. The Thailand authorities would like to thank the FSAP mission for the various reports and findings of Thailand's observance on standards and codes, and more particularly for the comprehensive sets of assessments and recommendations of the Thailand banking regulations as part of the FSAP. As the FSAP mission recognized the significance of the banking sector in Thailand, the mission also emphasized that the system enjoys a high degree of compliance with the BCP principles and objectives of banking 
regulation. Where there are gaps, without due delay, the authorities have already taken steps to implement some of the recommendations and are carefully considering the others to develop the policy agenda for further enhancing effective supervision. As banking activities are changing rapidly around the world, and the internationally accepted regulatory environments are swiftly evolving, our policy objectives in the coming years are to continue to work towards achieving optimal compliance with the existing BCPs and the revised BCPs, and equally ensuring the strength of our system for continued growth, stability, and the protection of consumers and market integrity.

\section{As reported in the Detailed Assessment (DA), Thailand fares satisfactorily well} in both essential and additional criteria in banking regulation system measuring against international best practices. The authorities would like to highlight some of those elements mentioned in the DA and those discussed during both missions so as to provide complete and balanced information in our response associated with this summary report.

58. We agree with the FSAP mission's findings that the laws had not kept pace with what we needed to perform our job in the past. While the explicit legal powers are to be preferred, the FSAP mission confirmed that they did not find interference and we have continued to press ahead to achieve the high quality outcomes. However, the legal infrastructure going forward will be greatly strengthened in line with international best practices. In December 2007, the National Legislative Assembly has passed the new FIBA and DPA, and the amendment of the BOT Act. Under the new FIBA, the BOT will have broad explicit supervisory power, including the authority to conduct consolidated supervision and take prompt corrective actions. The BOT will have sole responsibility for virtually all ongoing supervisory tasks, while the Minister retains the formal authority to grant or revoke licenses, but only on BOT's recommendation. The amended BOT Act will further enhance operational independence of the BOT as the Governor will be appointed on a fixed term basis (5 years), with conditions for premature dismissal explicitly specified in the law. The new DPA will provide explicit, limited deposit guarantee to depositors as well as reduce moral hazard in the financial sector.

59. As Basel II will be fully implemented in Thailand in 2008, BOT is committed to sound regulation and is actively considering the recommendations contained within the report for future policy outcomes. Under the current laws, BOT has implemented various regulations. The major regulation now in place includes the consolidated supervisory framework, which gives the broad range of powers to review the banking structure, its related parties and nominees. We also have developed an early warning system and bank resolution methodologies to enable BOT to take necessary, prompt corrective and preventive actions. In line with Pillar II, our continuous, supervisory review process has been strengthened and well-integrated into our system since 2001. The BOT examiners have been enforcing the minimum standards as set out by the current banking law. In addition, where necessary, they have been able to utilize qualitative judgment to gather and independently verify information, 
and applied a range of penalties when prudential requirements are not met or risks deemed to be material and concentrated. For this vigorous review, coupled with other global forces of change, market participants have responded positively by upgrading their systems and operational structures with more sophisticated risk management and more improved governance practices. As a result, the system reflects a level of strengthened capital adequacy with a low rate of new NPLs and reentry of restructured loans.

60. As mentioned in the DA, we have employed various channels of communication and cooperation, ranging from formalized MOU to making informal contacts. Such system of interagency cooperation and sharing of relevant information has been used for both domestic and foreign regulators. In the domestic context, through the functioning and membership of Financial Institutions Policy Committee (including representatives from MOF, SEC, DOI, the Council of State, Federation of Accounting Profession (FAP), and the Agricultural Futures Exchange), it provides an effective channel for co-ordination, especially in minimizing regulatory arbitrage and conducting problem bank resolution. At the technical level, we are also actively pursuing cooperation as recommended by the FSAP mission. This additional channel will be useful for system-wide policy implementations; first of which may include suitable measures to resolve the problem of legacy NPLs.

61. With respect to the role of Government in the banking system, particularly SFIs supervision, the economic and social objectives of SFIs, fitting in Thailand economic and social development context, should continue to be maintained in SFIs' operations in a foreseeable future. The international standard practices as recommended by the FSAP mission would help policymakers to come up with the most appropriate reform, design, fitting particular circumstances, for example the need of comprehensive, medium term strategy for the SFIs and a systematic process to evaluate the outcomes and cost effectiveness of government policy intervention. However, the MOF has to be cautious that the assessment is set as a prescriptive norm without certain flexibilities. Then, the application may be difficult to implement in Thailand.

\section{Role of SFIs}

62. SFIs are important and vital to provide financial services to specific groups such as the low-income households, farmers and infant SMEs. These groups are the backbone and blood line of the country and do not have access to normal financial markets.

63. The partial functions of SFIs may be the same as private commercial banks in providing banking services to the people. However the overlapping of the market segment between commercial banks and SFIs is insignificant. Most of SFIs customers are low and medium income people and in the provincial areas. SFIs provide loans with concessional terms and conditions. The amount of loans is very small compared with commercial banks. 
It inevitably confirms that Government Housing Bank (GHB) does not increasingly compete with commercial banks. 90 percent of the GHB lending portfolio is loans that are less than B 1 million.

64. Moreover, the operation of SFIs in the overlapped market segment does not undermine the role of the private financial sector, but it is considered as a benchmark for commercial banks to improve their operation.

\section{Deposit taking SFIs}

65. SFIs still need to be funded since one of the main missions of SFIs is to promote and enhance the saving discipline of Thailand people. Moreover, the deposit taking by GHB, Bank for Agriculture and Agricultural Cooperatives and Government Savings Bank (GSB) (SME Bank is not a deposit taking institution) are different from commercial banks. Most of the deposits placed are from their borrowers and mostly low-income home owners and farmers.

66. Since SFIs serve as the development bank and the mechanism of the government to fill the gap of financial services rendering and to support the country's economic policy. Therefore, it is the responsibility of the MOF as the economy oversight agency to supervise the SFIs with a special supervisory framework to facilitate the work on their main mandate and mission. However, the direction and policy to comply with the international prudential standards is clear and MOF and all SFIs are well aware.

\section{As the SFIs supervisory authority, MOF works under the certain legal} framework in each Enabling Acts identifies the key prudential regulation that need to be exploited. Furthermore, MOF also has been increasing prudential regulation in key areas such as capital adequacy, liquidity asset, asset classification and provisioning based on their specific characters by Ministry Regulation or Declaration. It could be stated that the way SFIs have been supervised has been appropriate. Regarding the past performance of the SFIs since the financial crisis, SFIs did not suffer the same problems as the commercial banks and the government had assigned SFIs as a public mechanism to revitalize the Thailand economy. In addition, the SFIs have been doing well in certain segments. For example, in the housing market, it has commanded almost half of the market share and mostly because the commercial banks could not provide mortgage loans.

68. Beside the compulsory work, the MOF is on the process to strengthen efficiency quality and transparency of SFIs supervision. Ongoing projects that will enhance the monitoring framework further from an annual basis are SFIs Monitoring and Reporting System, Information Dissemination through the FPO website and the NPL Resolution plan (year 2006-2008). 
69. With the special supervisory framework, there might be a competitive advantage of SFIs over other financial institutions; for example SFIs are exempted from corporate income tax (30 percent), specific business tax (3.3 percent) and stamp duties. However, SFIs as State-Owned Enterprises are subjected to commitment of revenue remittance. GSB, GHB and EXIM are required to remit 35-45 percent of their profit to the MOF. Their revenue remittance is compatible (more or less) to corporate tax payment (Table 7).

Table 7. Thailand: SFI Revenue Remittance

\begin{tabular}{lccrr}
\hline & \multicolumn{2}{c}{ Minimum Requirement (in percent) } & \multicolumn{2}{c}{ Unit: Million Baht } \\
\cline { 2 - 5 } & $\begin{array}{c}\text { Remittance Ratio* } \\
\text { as of 2004 }\end{array}$ & $\begin{array}{c}\text { Remittance Ratio* } \\
\text { as of 2007 }\end{array}$ & FY2006 & FY2007 \\
\hline GSB & 35 & 45 & $6,000.00$ & $6,557.06$ \\
Remittance Ratio (\%) & & & 59.20 & 57.12 \\
GHB & 35 & 40 & $1,893.00$ & $1,988.6$ \\
Remittance Ratio (\%) & & & 41.50 & 41.38 \\
EXIM & 35 & 35 & 161 & 200.45 \\
Remittance Ratio (\%) & & & 30.64 & 33.48 \\
& & & $8,054.00$ & $8,746.11$ \\
\hline Total & & & & \\
\hline
\end{tabular}

*Remittance Ration - \% of profit remitted to MOF.

\section{B. Summary Assessment of Implementation of the IOSCO Principles}

70. Thailand has a fundamentally sound system for regulation of its capital markets. The effectiveness of the regulatory system could be improved by providing the Thailand SEC with the legal authority to file civil enforcement actions to address misconduct and to impose monetary penalties administratively. Regulatory effectiveness would also be enhanced if the SEC Board is restructured for greater independence, if there is increased coordination of policy decisions and policy implementation among government agencies and responsibility for licensing financial intermediaries is transferred from the MOF to the SEC. The adoption of International accounting standards will likely result in a significant need for interpretive guidance on application. The Thailand Federation of Accounting Profession will likely require additional professional staff to meet this need.

\section{Information and methodology used for assessment}

71. This is an assessment of the SEC. This assessment was conducted in January, 2007 by Mr. Jonathan Katz, a technical advisor to the World Bank, as part of the FSAP. 


\section{Institutional and market structure-Overview}

72. The SET was created by law in $\mathbf{1 9 7 5}$ and the Thailand Futures Exchange (TFEX), a wholly owned subsidiary of the SET, began operation in 2006. Equity trading of listed companies must occur on the SET. There are 518 listed companies on the SET, with a total market capitalization of approximately B 5 billion (as of December 2006). Daily trading averages B 16.3 billion. Retail investors account for over 55 percent of daily trading. Foreign investors account for 34 percent and institutional investors for the remaining 11 percent. Only one product is currently available on the TFEX, a SET50 future.

73. The Thailand securities markets have grown significantly in the past ten years. However the growth has slowed in the past year. Market valuations following the market declines in fall 2006 are relatively low, with a typical P/E ratio of less than 10 . The market capitalization is heavily concentrated. The ten largest cap companies represent approximately 40 percent of the total market cap. The government continues to own a substantial portion of these largest companies and when combined with control person ownership, this results in limited liquidity for the remaining freely floating shares.

74. The brokerage community in Thailand is small and not well capitalized. The MOF has not awarded a new brokers license in ten years, preferring that new entrants purchase an existing firm. There are currently 41 licensed firms and these firms rely heavily on commission fees for revenue (estimated at 75 percent of total industry revenue). Because commission rates are fixed by the SET, there is little incentive to invest in other business areas. Many firms appear to rely heavily upon day trading by retail investors for commission revenue.

75. One of the perceived reasons for the low equity valuation and market liquidity is the small size of the institutional investor community in Thailand. Mutual funds in Thailand are largely invested in government debt and private pension investment is similarly low. As of December 2006, there were 18 asset management companies managing 807 mutual funds, with total assets of approximately B 1,222.5 billion.

76. The debt market in Thailand is conducted primarily in an informal over-thecounter (OTC) manner. The Thailand Bond Market Association (TBMA) publishes government trades upon receipt and corporate trades twice daily. Daily liquidity in the Thailand bond market (corporate and government) is limited. Excluding bank repo transactions, the number of transactions is typically less than 300, with as few as one crossed through the SET electronic system. The total estimated value of the corporate debt market is approximately B 1 trillion but the value of the daily trading is less than 3 percent of the total.

77. The SEC was created in 1992 with the enactment of the SEA Act B.E. 2535

(SEA). The SEC is headed by a Board comprised of 11 members. Five members are ex 
officio including the MOF, who is the Board Chair, the Governor of the BOT, the Permanent Secretaries of the MOF and Commerce, the Secretary-General of the SEC and 4-6 members are appointed by the Cabinet following the recommendation by the MOF. Board members are appointed for staggered fixed six year terms. The appointed members must include at least one legal expert, one accounting expert and one financial expert. None of the 4-6 expert members appointed by the Cabinet may be a political official.

\section{Preconditions for effective securities regulation}

\section{The Thailand securities laws are fundamentally sound and comprehensive.}

However, there is a need for specific amendments to the law in areas pertaining to SEC enforcement authority; SEC and TSD authority to act in the event that a licensed broker fails, to prevent one firm's failure from causing systemic failures in the industry; and implementation of key shareholder protections identified in a 2005 ROSC on corporate governance. Each of these issues is discussed in the detailed assessment.

\section{Main Findings of principle by principle assessment}

\section{Table 8. Thailand: Summary Implementation of the IOSCO Principles-ROSCs}

\begin{tabular}{|c|c|}
\hline Principle & Findings \\
\hline $\begin{array}{l}\text { Principle } 1 . \text { The responsibilities of the regulator } \\
\text { should be clearly and objectively stated }\end{array}$ & $\begin{array}{l}\text { The law provides a clear statement of the responsibilities of } \\
\text { the SEC Board for policy and the Secretary General for } \\
\text { operations. } \\
\text { There does not appear to be a formal coordination mechanism } \\
\text { to enable the SEC to participate in policy decisions that might } \\
\text { materially affect the Thailand capital markets. }\end{array}$ \\
\hline $\begin{array}{l}\text { Principle } 2 . \text { The regulator should be operationally } \\
\text { independent and accountable in the exercise of its } \\
\text { functions and powers }\end{array}$ & $\begin{array}{l}\text { While the SEC Board does not involve itself in day to day } \\
\text { operations, the law suggests that a Board could do so and it } \\
\text { empowers the Minister of Finance to be directly involved in } \\
\text { the SEC's daily operational activities and with the potential } \\
\text { that it can overrule any working decisions of the SEC SG. } \\
\text { Although this has not been the practice, it is possible and } \\
\text { would jeopardize the independence of the SEC. }\end{array}$ \\
\hline $\begin{array}{l}\text { Principle } 3 \text {. The regulator should have adequate } \\
\text { powers, proper resources and the capacity to perform } \\
\text { its functions and exercise its powers }\end{array}$ & $\begin{array}{l}\text { The policy of restricting the total number of securities firm } \\
\text { licenses creating an impairment to fair and effective } \\
\text { regulation. }\end{array}$ \\
\hline $\begin{array}{l}\text { Principle } 4 . \text { The regulator should adopt clear and } \\
\text { consistent regulatory processes }\end{array}$ & $\begin{array}{l}\text { Official government actions must be published in the } \\
\text { Thailand Official Gazette. The public release of inspection } \\
\text { report summaries and grades is a positive innovation. }\end{array}$ \\
\hline $\begin{array}{l}\text { Principle } 5 . \text { The staff of the regulator should observe } \\
\text { the highest professional standards }\end{array}$ & $\begin{array}{l}\text { SEC restrictions on employee investments should apply to } \\
\text { employees' spouses and minor children and to any accounts } \\
\text { controlled by an SEC employee. The SEC should verify } \\
\text { compliance by reviewing employee accounts. }\end{array}$ \\
\hline $\begin{array}{l}\text { Principle } 6 \text { The regulatory regime should make } \\
\text { appropriate use of self-regulatory organizations }\end{array}$ & See Principle 7 \\
\hline
\end{tabular}




\begin{tabular}{|c|c|}
\hline Principle & Findings \\
\hline $\begin{array}{l}\text { (SROs) that exercise some direct oversight } \\
\text { responsibility for their respective areas of } \\
\text { competence and to the extent appropriate to the size } \\
\text { and complexity of the markets }\end{array}$ & \\
\hline $\begin{array}{l}\text { Principle 7. SROs should be subject to the oversight } \\
\text { of the regulator and should observe standards of } \\
\text { fairness and confidentiality when exercising powers } \\
\text { and delegated responsibilities }\end{array}$ & $\begin{array}{l}\text { The SEC requires additional legal authority to review all SET } \\
\text { rules and authority to review any disciplinary action taken by } \\
\text { the SET. }\end{array}$ \\
\hline $\begin{array}{l}\text { Principle } 8 . \text { The regulator should have } \\
\text { comprehensive inspection, investigation and } \\
\text { surveillance powers }\end{array}$ & $\begin{array}{l}\text { The SEC should have the authority to obtain a court order to } \\
\text { compel compliance with investigative subpoenas. }\end{array}$ \\
\hline $\begin{array}{l}\text { Principle } 9 . \text { The regulator should have } \\
\text { comprehensive enforcement powers }\end{array}$ & $\begin{array}{l}\text { The SEC requires legal authority to bring civil actions to } \\
\text { police the capital markets. }\end{array}$ \\
\hline $\begin{array}{l}\text { Principle } 10 . \text { The regulatory system should ensure an } \\
\text { effective and credible use of inspection, investigation, } \\
\text { surveillance and enforcement powers and } \\
\text { implementation of an effective compliance program. }\end{array}$ & $\begin{array}{l}\text { The SEA should be amended to remedy gaps in legal } \\
\text { definitions for insider trading and market manipulation. }\end{array}$ \\
\hline $\begin{array}{l}\text { Principle } 11 \text { The regulator should have the authority } \\
\text { to share both public and nonpublic information with } \\
\text { domestic and foreign counterparts }\end{array}$ & $\begin{array}{l}\text { The SEC has clear authority to broadly share information that } \\
\text { it possesses. Impediments are discussed in Principle } 13 \text {. }\end{array}$ \\
\hline $\begin{array}{l}\text { Principle } 12 . \text { Regulators should establish information } \\
\text { sharing mechanisms that set out when and how they } \\
\text { will share both public and nonpublic information } \\
\text { with their domestic and foreign counterparts }\end{array}$ & $\begin{array}{l}\text { The SEC and BOT have different interpretations on sharing tha } \\
\text { should be resolved. }\end{array}$ \\
\hline $\begin{array}{l}\text { Principle } 13 \text {. The regulatory system should allow for } \\
\text { assistance to be provided to foreign regulators who } \\
\text { need to make inquiries in the discharge of their } \\
\text { functions and exercise of their powers }\end{array}$ & $\begin{array}{l}\text { The SEC is unable to seek and provide information to foreign } \\
\text { regulators unless it has its own interest in the matter. }\end{array}$ \\
\hline $\begin{array}{l}\text { Principle 14. There should be full, timely and } \\
\text { accurate disclosure of financial results and other } \\
\text { information that is material to investors' decisions }\end{array}$ & $\begin{array}{l}\text { The SEC disclosure system is comprehensive as is its } \\
\text { procedures for review, onsite visits by staff and a review of } \\
\text { auditor work papers. }\end{array}$ \\
\hline $\begin{array}{l}\text { Principle } 15 . \text { Holders of securities in a company } \\
\text { should be treated in a fair and equitable manner }\end{array}$ & $\begin{array}{l}\text { Changes in the law are required to implement the } \\
\text { recommendations contained in the } 2005 \text { ROSC on corporate } \\
\text { governance. }\end{array}$ \\
\hline $\begin{array}{l}\text { Principle 16. Accounting and auditing standards } \\
\text { should be of a high and internationally acceptable } \\
\text { quality }\end{array}$ & $\begin{array}{l}\text { The FAP is completing the transition to IFRS and will require } \\
\text { greater resources for interpretation and application. }\end{array}$ \\
\hline $\begin{array}{l}\text { Principle } 17 . \text { The regulatory system should set } \\
\text { standards for the eligibility and the regulation of } \\
\text { those who wish to market or operate a collective } \\
\text { investment scheme }\end{array}$ & $\begin{array}{l}\text { There is a comprehensive system for licensing and inspecting } \\
\text { fund operators and of funds. }\end{array}$ \\
\hline $\begin{array}{l}\text { Principle } 18 . \text { The regulatory system should provide } \\
\text { for rules governing the legal form and structure of } \\
\text { collective investment schemes and the segregation } \\
\text { and protection of client assets }\end{array}$ & $\begin{array}{l}\text { A system for licensing mutual fund operators and non- } \\
\text { affiliated mutual fund trustees is in place. Fund trustees are } \\
\text { the custodians for all fund assets. }\end{array}$ \\
\hline $\begin{array}{l}\text { Principle 19. Regulation should require disclosure, as } \\
\text { set forth under the principles for issuers, which is } \\
\text { necessary to evaluate the suitability of a collective }\end{array}$ & $\begin{array}{l}\text { The SEC has a comprehensive regulatory scheme for mutual } \\
\text { fund disclosure including a required annual audit. }\end{array}$ \\
\hline
\end{tabular}




\begin{tabular}{|c|c|}
\hline Principle & Findings \\
\hline $\begin{array}{l}\text { investment scheme for a particular investor and the } \\
\text { value of the investor's interest in the scheme }\end{array}$ & \\
\hline $\begin{array}{l}\text { Principle 20. Regulation should ensure that there is a } \\
\text { proper and disclosed basis for assets valuation and } \\
\text { the pricing and the redemption of units in a collective } \\
\text { investment scheme }\end{array}$ & $\begin{array}{l}\text { All mutual funds must do a daily Net Asset Value (NAV) } \\
\text { calculation in accordance with AIMC guidelines, approved by } \\
\text { the SEC. }\end{array}$ \\
\hline $\begin{array}{l}\text { Principle } 21 \text {. Regulation should provide for minimum } \\
\text { entry standards for market intermediaries }\end{array}$ & $\begin{array}{l}\text { The current system requires new entrants to purchase existing } \\
\text { licenses from defunct entities. }\end{array}$ \\
\hline $\begin{array}{l}\text { Principle } 22 . \text { There should be initial and ongoing } \\
\text { capital and other prudential requirements for market } \\
\text { intermediaries that reflect the risks that the } \\
\text { intermediaries undertake }\end{array}$ & $\begin{array}{l}\text { SEC rules require adequate levels of operating capital and } \\
\text { provide for ongoing reporting. }\end{array}$ \\
\hline $\begin{array}{l}\text { Principle 23. Market intermediaries should be } \\
\text { required to comply with standards for internal } \\
\text { organization and operational conduct that aim to } \\
\text { protect the interests of clients, ensure proper } \\
\text { management of risk, and under which management of } \\
\text { the intermediary accepts primary responsibility for } \\
\text { these matters }\end{array}$ & $\begin{array}{l}\text { Intermediaries must have internal compliance and internal } \\
\text { independent audit units and risk management systems } \\
\text { approved by the broker's board of directors. Firms must also } \\
\text { have internal control procedures over access to nonpublic } \\
\text { confidential information. }\end{array}$ \\
\hline $\begin{array}{l}\text { Principle } 24 \text {. There should be a procedure for dealing } \\
\text { with the failure of a market intermediary in order to } \\
\text { minimize damage and loss to investors and to contain } \\
\text { systemic risk }\end{array}$ & $\begin{array}{l}\text { The SEC lacks authority to take action when a firm fails to } \\
\text { safeguard investor funds and assets. The TSD and SET fund } \\
\text { is available only for the settlement of outstanding trades. Also } \\
\text { a coordination plan should be developed with other } \\
\text { government regulators to provide early warning of a failure } \\
\text { that might migrate from one financial intermediary to another. }\end{array}$ \\
\hline $\begin{array}{l}\text { Principle } 25 \text {. The establishment of trading systems } \\
\text { including securities exchanges should be subject to } \\
\text { regulatory authorization and oversight }\end{array}$ & $\begin{array}{l}\text { Both the SET and TFEX are authorized under Thai law (the } \\
\text { SET predated the enactment of the SEA) and are directly } \\
\text { supervised by the SEC. }\end{array}$ \\
\hline $\begin{array}{l}\text { Principle } 26 \text {. There should be ongoing regulatory } \\
\text { supervision of exchanges and trading systems, which } \\
\text { should aim to ensure that the integrity of trading is } \\
\text { maintained through fair and equitable rules that strike } \\
\text { an appropriate balance between the demands of } \\
\text { different market participants }\end{array}$ & $\begin{array}{l}\text { The SEC has limited authority to review SET rules pertaining } \\
\text { to trading and operations. }\end{array}$ \\
\hline $\begin{array}{l}\text { Principle 27. Regulation should promote transparency } \\
\text { of trading }\end{array}$ & $\begin{array}{l}\text { Equity trading transparency appears sound. While there have } \\
\text { been significant improvements in bond market transparency, } \\
\text { further improvements are required. }\end{array}$ \\
\hline $\begin{array}{l}\text { Principle 28. Regulation should be designed to detect } \\
\text { and deter manipulation and other unfair trading } \\
\text { practices }\end{array}$ & $\begin{array}{l}\text { Legal interpretations make action on insider trading and } \\
\text { market manipulation difficult. The SEC lacks the authority to } \\
\text { file civil actions. }\end{array}$ \\
\hline $\begin{array}{l}\text { Principle 29. Regulation should aim to ensure the } \\
\text { proper management of large exposures, default risk } \\
\text { and market disruption }\end{array}$ & $\begin{array}{l}\text { The SEC and the SET/TSD do not have clear authority to act } \\
\text { to avoid systemic market disruption if one firm fails. }\end{array}$ \\
\hline $\begin{array}{l}\text { Principle } 30 \text {. Systems for clearing and settlement of } \\
\text { securities transactions should be subject to regulatory } \\
\text { oversight, and designed to ensure that they are fair, } \\
\text { effective and efficient and that they reduce systemic } \\
\text { risk }\end{array}$ & $\begin{array}{l}\text { Assessed separately. See the Report of the Observance of } \\
\text { Standards and Codes: CPSS/IOSCO Assessment of Securities } \\
\text { Settlement System. }\end{array}$ \\
\hline
\end{tabular}




\section{Table 9. Thailand: Recommended Action Plan to Improve Implementation of the IOSCO Principles}

\begin{tabular}{|c|c|}
\hline Reference Principle & Recommended Action \\
\hline Principles Relating to the Regulator (P 1-5) & $\begin{array}{l}\text { Create a formal coordination mechanism among governmental } \\
\text { agencies with regulatory authority over the capital markets. } \\
\text { Transfer final licensing authority over securities firms and mutual } \\
\text { fund administrators to the SEC. } \\
\text { Confirm that the Minister of Finance does not have authority } \\
\text { over the daily operational activities of the SEC. } \\
\text { The SEC should publish for public consultation the complete text } \\
\text { of its draft regulations in addition to its summaries. }\end{array}$ \\
\hline Principles of Self-Regulation (P 6-7) & $\begin{array}{l}\text { The SEA should be amended to enable the SEC to review and } \\
\text { approve or require changes to all SET rules and to review SRO } \\
\text { disciplinary actions. The FAP requires additional resources to } \\
\text { perform its required functions. }\end{array}$ \\
\hline $\begin{array}{l}\text { Principles for the Enforcement of Securities } \\
\text { Regulation (P 8-10) }\end{array}$ & $\begin{array}{l}\text { The SEC should examine the adequacy of surveillance of the } \\
\text { OTC debt market. The SEA should be amended so the SEC } \\
\text { independently files civil enforcement actions. This authority } \\
\text { should include money sanctions, restitution to investors, and the } \\
\text { ability to order corrective action. The SEC should be given the } \\
\text { authority to temporarily suspend trading in individual securities. } \\
\text { The SEC should obtain the authority to refer criminal actions } \\
\text { directly to the Public Prosecutor. } \\
\text { A private class action legal case should be permitted. }\end{array}$ \\
\hline Principles for Cooperation in Regulation (P 11-13) & $\begin{array}{l}\text { A formal MOU with other Thailand regulatory bodies should be } \\
\text { finalized, providing for a full exchange of information. A } \\
\text { coordinating body of senior officials should be created for the } \\
\text { exchange of regulatory ideas and discussion of regulatory } \\
\text { policies. } \\
\text { The SEA should be amended to enable the SEC to seek } \\
\text { information on behalf of foreign regulatory bodies, consistent } \\
\text { with international standards for cooperation. }\end{array}$ \\
\hline Principles for Issuers (P 14-16) & $\begin{array}{l}\text { The SEA should be amended in accordance with the } 2005 \text { ROSC } \\
\text { on corporate governance. }\end{array}$ \\
\hline $\begin{array}{l}\text { Principles for Collective Investment Schemes } \\
(\text { P 17-20) }\end{array}$ & No significant recommended actions \\
\hline Principles for Market Intermediaries (P 21-24) & $\begin{array}{l}\text { The restriction on new securities dealers' licenses is inconsistent } \\
\text { with an equitable application of licensing policy. The } 2012 \\
\text { deadline should not be extended. } \\
\text { The highest priority should be empowering the SEC to take all } \\
\text { necessary action, such as the authority to appoint a liquidator or } \\
\text { receiver to protect customer accounts and to preserve assets of a } \\
\text { securities firm that fails. Related issues of bankruptcy law } \\
\text { protection for customer assets held in street name, and settlement } \\
\text { integrity for unsettled transactions should also be addressed. }\end{array}$ \\
\hline
\end{tabular}


Principles for the Secondary Market (P 25-30)

Transparency in the equity market is sound and improving in the debt market. Further efforts may be appropriate, such as creation of better depth of book disclosure for equities and meaningful electronic disclosure of dealer quotes in the debt market.

\section{Authorities' response}

\section{General view}

79. Joining FSAP is a very fruitful experience for the SEC, Thailand. The assessment results reflect a satisfactory level of implementation of IOSCO Principles and can serve as an assurance that Thailand's securities regulation is on par with international best practices. Major weaknesses identified, most of which involve limitations in our legal authority, have been treated as highest priorities in our ongoing law amendment agenda.

\section{Independence of the SEC}

80. In practice, the SEC has operational independence in carrying out its day-to-day activities. Though the mission views that a certain provision (262) in the securities law is theoretically open for possible involvement by the Finance Minister in SEC daily decisions, the provision has never been invoked by any Minister.

81. The SEC is aware that the existing composition of the SEC Board, with the Minister of Finance as Chair and a number of government appointees, cannot be considered independent, though in practice the Minister has never involved in the SEC's daily activities. With an effort to strengthen independence in this regard, an amendment to the existing law has been proposed to restructure composition of the SEC Board and improve appointment and dismissal process of Board members. The draft law amendment is now in the process of enactment.

\section{Enforcement powers}

82. The mission's recommendation for the SEC to have the power to file civil enforcement actions independently, including the power to impose money sanctions against the violators of the SEC Act would help enhance the SEC's enforcement authority significantly. Apart from civil power, the SEC considers that improvement in administrative power, particularly imposition of administrative sanctions on those who are not regulated persons or entities under the SEC Act, is also important. For instance, the explicit power to bar or blacklist a person from being a director of a listed company would be a meaningful tool to enforce our regulations in relation to good corporate governance and further enhance effectiveness of law enforcement. 


\section{Authority to deal with a failing securities firm}

83. The SEC is aware of the gap in its legal authority to deal with the eventuality of a failing securities firm and a draft amendment to the SEC Act has been proposed and accepted by the Cabinet. This amendment, when effective, would give the SEC the power to segregate and administer client assets in the event of a firm's failure. Indeed, the amended SEC Act was passed on August 7, 2007, after the completion of the assessment and as such eliminates the uncertainties in TSD functioning as a settlement counterparty.

\section{Summary Assessment Observance of the Transparency Code in Monetary Policy}

84. While a culture of monetary policy transparency has been firmly established by the BOT, further challenges remain in particular on the legal framework. The generally high observance of sound monetary policy transparency principles is primarily the result of extensive efforts on the part of the BOT to overcome the legal shortcomings through a highly open process for formulating and reporting on monetary policy. Changes in the monetary policy stance are regularly explained to the public. Information on the specification and use of the BOT's monetary instruments is publicly disclosed and the BOT meets the standards on data reporting on monetary and financial statistics.

85. Significantly weighing on monetary policy transparency, the objectives of monetary policy are not defined in any of the Acts. While in practice, the government does not interfere with the policy formulation and operation of the BOT, the law allows the MOF to have the authority over the BOT's operation and the conditions under which the MOF is permitted to do so are not spelled out. In addition, the terms of office for the Governor and Deputy Governors are not spelled out in legislation and the Governor can be removed from office by the Crown upon recommendation of the Cabinet. This inevitably raises questions about the clarity of the role and the responsibilities for monetary policy between the BOT and the MOF.

86. Recommended actions to improve monetary policy transparency require primarily legal amendments, to the BOT Act, the Royal Decree and the Currency Act, and these should be addressed urgently. Among the most important ones are: clarify the primary objective of monetary policy in the BOT Act; assure the BOT's full operational independence and accountability; clarify the role of the MOF in BOT's decision making process; and spell out the terms of office of the Governor and Deputy Governors. Other recommendations to further enhance transparency of monetary policy do not warrant placement at the top of the reform agenda at this time. These include moving toward a consolidated balance sheet and income statement to further enhance overall transparency. While the BOT accounts are independently audited by the Office of the Auditor General of Thailand, which is consistent with the Code on Monetary Policy Transparency, the BOT 
would benefit from having its financial account audited, in parallel, by an independent private accounting firm.

87. The BOT is in the process of amending the BOT Act, and the proposed amendments would help, if enacted, address several of the institutional shortcomings in monetary policy transparency. The amendments of the BOT Act have been approved in principle by the Cabinet on February 27, 2007 and are now under review by the Council of State for legal clearance.

\section{Introduction}

88. This assessment covers the transparency of monetary policy in the Kingdom of Thailand, and in particular its formulation and implementation by the BOT in the context of the government's overall economic strategy. It forms part of the FSAP for Thailand, which was conducted jointly by the IMF and the World Bank during 2007. The assessment was undertaken during the first FSAP mission in January 2007, with additional discussions during the second mission early June 2007. The main assessor was Ms. Jeanne Gobat of the Monetary and Capital Markets Department of the IMF.

\section{Information and methodology used for assessment}

89. The assessment is based on information available in January and March 2007, and specifically on a review of relevant laws and regulations then in force, publications issued by the Thailand authorities, speeches and presentations, and material provided and posted on the BOT's website; the authorities' response to the questionnaire and their self-assessment of observance of the code; and discussions held with the authorities at senior level and among various departments and divisions of the BOT and financial sector representatives. The authorities cooperated fully, and generously provided materials and time for discussion.

\section{Institutional structure-Overview}

90. The current institutional arrangement governing the implementation of monetary and exchange rate policy is complex. The MOF is in charge of the BOT Act, the Currency Act and the Exchange Control Act. The powers and duties described under the Currency Act and the Exchange Control Act have been delegated to the BOT. In addition, the Royal Decree issued under the BOT Act describes the instruments, duties and transactions that the BOT is authorized to conduct. The BOT under the current legal arrangement is responsible for the conduct of monetary policy and implementation of exchange rate policy, foreign reserve management and the management of exchange controls, as well as note and currency issuance. There are some weaknesses in the current institutional arrangement. Specifically, the objectives of monetary policy are not defined in 
any of the Acts. Also, the operational autonomy of the BOT is constrained as the MOF is given the power to supervise the activities of the BOT (Section 14 of the BOT Act) and the Governor can be removed from office by the Crown upon recommendation of the Cabinet.

91. The BOT is what generally is known as a statutory body and a juristic person capable of suing and being sued. The governing body of the BOT is the Court of Directors (CoD), consisting of the Governor (Chairman of the CoD), three deputy governors as Vice Chairman and at least five non-executive directors. The Governor and deputy governors are appointed or removed by the Crown upon the recommendation of the Cabinet while all other CoD directors are appointed and removed by the Cabinet upon the recommendation of the MOF. There are also the Audit Committee that reports to the CoD and the Top Management Committee, which consists of high-level executives of the BOT, acting as executive board of BOT.

92. While the BOT Act specifies a narrow mandate for the BOT, its duties and activities are expanded under the Royal Decree Regulating the Affairs of the Bank of Thailand. The BOT has the power to set interest rates for its standing facilities and rediscount paper; buy and sell debt instruments and foreign exchanges and extend credits to financial institutions against eligible collateral. Under the Royal Decree, the BOT cannot pay interest rates on any type of uncollateralized deposits. While the BOT needs to ask for MOF permission for the overall outstanding size of BOT bonds, it determines the tenors, the auction amount and the frequency of BOT bond issuance.

93. Although monetary policy objectives are not explicitly stated in the BOT Act, the BOT has been de facto implementing an inflation targeting (IT) framework since May 2000. The BOT targets the quarterly average core inflation range of $0-3.5$ percent. The Monetary Policy Committee (MPC) is the policy body responsible for setting monetary policy in the context of inflation targeting. The MPC signals shifts in monetary policy stance through announced changes in its key policy rate, the 1-day overnight RP rate. In the context of inflation targeting, the BOT manages a floating exchange rate regime. This has been in place since July 2, 1997 when the government of Thailand abandoned the pegged exchange rate regime. Under the current regime, the exchange rate is market determined, although the BOT manages the exchange rate by intervening in the foreign exchange market from time to time and occasionally through the use of exchange controls. 


\section{Main findings}

\section{Table 10. Thailand: Summary Observance of the Transparency Code (Monetary Policy)}

\begin{tabular}{|c|c|c|}
\hline $\begin{array}{r}\text { Principle } \\
\end{array}$ & Grading & Description \\
\hline $\begin{array}{l}\text { 1.1 The ultimate objective(s) and institutional } \\
\text { framework of monetary policy should be clearly } \\
\text { defined in relevant legislation or regulation, } \\
\text { including, where appropriate, a central bank law }\end{array}$ & $\mathrm{PO}$ & $\begin{array}{l}\text { The BOT Act does not specify the objectives of } \\
\text { monetary policy. } \\
\text { The BOT Act, the Royal Decree, and the } \\
\text { delegated duties and powers under the Currency } \\
\text { Act and Exchange Control Act spell out the } \\
\text { institutional framework of monetary policy, } \\
\text { including the scope of transactions that the BOT } \\
\text { can conduct. }\end{array}$ \\
\hline $\begin{array}{l}1.2 \text { The institutional relationship between } \\
\text { monetary and fiscal operations should be clearly } \\
\text { defined }\end{array}$ & $\mathrm{BO}$ & $\begin{array}{l}\text { The institutional relationship between monetary } \\
\text { and fiscal operations is not clearly defined, } \\
\text { although representation of external members in } \\
\text { the MPC from various government ministries } \\
\text { provides a channel for co-ordination. } \\
\text { The Royal Decree specifies the conditions under } \\
\text { which the BOT is permitted to provide credits to } \\
\text { the government. The allocation of profits and } \\
\text { maintenance of capital are described in the BOT } \\
\text { Act. }\end{array}$ \\
\hline $\begin{array}{l}\text { 1.3 Agency roles performed by the central bank } \\
\text { on behalf of the government should be clearly } \\
\text { defined }\end{array}$ & $\mathrm{O}$ & This is defined in the Royal Decree. \\
\hline $\begin{array}{l}2.1 \text { The framework, instruments, and any targets } \\
\text { that are used to pursue the objectives of monetary } \\
\text { policy should be publicly disclosed and explained }\end{array}$ & $\mathrm{O}$ & $\begin{array}{l}\text { The IT framework, objectives, targets and } \\
\text { instruments of monetary policy are explained on } \\
\text { the BOT's website, the Annual Economic Report, } \\
\text { the quarterly Inflation Report, reports of MPC } \\
\text { decisions, and through other means. }\end{array}$ \\
\hline $\begin{array}{l}2.2 \text { Where a permanent monetary policy making } \\
\text { body meets to assess underlying economic } \\
\text { developments, monitor progress toward } \\
\text { achieving its monetary policy objective(s), and } \\
\text { formulate policy for the period ahead, } \\
\text { information on the composition, structure, and } \\
\text { functions of that body should be publicly } \\
\text { disclosed }\end{array}$ & $\mathrm{O}$ & $\begin{array}{l}\text { The MPC is responsible for setting the direction } \\
\text { of monetary policy. The information on the } \\
\text { MPC's responsibilities, composition, structure, } \\
\text { functions, and code of conduct are disclosed } \\
\text { through the BOT website }{ }^{14} \text { and the quarterly } \\
\text { Inflation Report. }\end{array}$ \\
\hline
\end{tabular}

14 http://www.bot.or.th/BOTHomepage/BankAtWork/Monetary\&FXPolicies/Monet_Policy/mpb/8-23-2000-Engi/mpb.htm 


\begin{tabular}{|c|c|c|}
\hline Principle & Grading & Description \\
\hline $\begin{array}{l}2.3 \text { Changes in the setting of monetary policy } \\
\text { instruments (other than fine-tuning measures) } \\
\text { should be publicly announced and explained in a } \\
\text { timely manner }\end{array}$ & $\mathrm{O}$ & $\begin{array}{l}\text { Changes in monetary policy are announced and } \\
\text { explained in a timely manner. The press release is } \\
\text { issued following the press conference which takes } \\
\text { place following every MPC meeting. The MPC } \\
\text { press releases are posted to the BOT website on } \\
\text { the same day of the meeting. More substantial } \\
\text { changes are discussed with market participants } \\
\text { ahead of their introduction and explained well in } \\
\text { advance. }\end{array}$ \\
\hline $\begin{array}{l}2.4 \text { The central bank should issue periodic public } \\
\text { statements on progress toward achieving its } \\
\text { monetary policy objective(s) as well as prospects } \\
\text { for achieving them. The arrangements could } \\
\text { differ depending on the monetary policy } \\
\text { framework, including the exchange rate regime }\end{array}$ & $\mathrm{O}$ & $\begin{array}{l}\text { Progress toward achieving the monetary policy } \\
\text { objective is discussed in the Inflation Report, at } \\
\text { the press conference following the MPC meeting, } \\
\text { at the "Quarterly Economic Assessment and } \\
\text { Outlook" forum, and at the press conference to } \\
\text { release the Thailand edition of the Inflation } \\
\text { Report. A shorter English version of the press } \\
\text { conference and the Inflation Report are also } \\
\text { immediately released. }\end{array}$ \\
\hline $\begin{array}{l}2.5 \text { For proposed substantive technical changes to } \\
\text { the structure of monetary regulations, there } \\
\text { should be a presumption in favor of public } \\
\text { consultations, within an appropriate period }\end{array}$ & $\mathrm{O}$ & $\begin{array}{l}\text { Technical changes to the structure of monetary } \\
\text { regulations are announced and explained to } \\
\text { relevant parties (e.g., official letters, public } \\
\text { consultations). For changes with wide-ranging } \\
\text { effects, such as the shift in the monetary policy } \\
\text { framework from monetary to inflation targeting } \\
\text { in } 2000 \text {, public consultations were held. Public } \\
\text { consultations were also held in advance with the } \\
\text { switch in the policy rate from the 14-day fixed } \\
\text { RP rate to the 1-day overnight RP rate and with } \\
\text { the closure of the BOT-run RP market, planned } \\
\text { for second half of 2007. }\end{array}$ \\
\hline $\begin{array}{l}\text { 2.6 The regulations on data reporting by financial } \\
\text { institutions to the central bank for monetary } \\
\text { policy purposes should be publicly disclosed }\end{array}$ & $\mathrm{O}$ & $\begin{array}{l}\text { Data reporting by banks is governed by the terms } \\
\text { and conditions of the Commercial Banking Act } \\
\text { B.E. } 2505 \text { available on the BOT website. }\end{array}$ \\
\hline $\begin{array}{l}\text { 3.1 Presentations and releases of central bank } \\
\text { data should meet the standards related to } \\
\text { coverage, periodicity, timeliness of data and } \\
\text { access by the public that are consistent with the } \\
\text { International Monetary Fund's data } \\
\text { dissemination standards }\end{array}$ & $\mathrm{O}$ & $\begin{array}{l}\text { Thailand subscribes to the Special Data } \\
\text { Dissemination Standards (SDDS) since } 1996 . \\
\text { The coverage, frequency and timeliness of } \\
\text { publication of statistics on monetary and foreign } \\
\text { exchange developments meet the SDDS } \\
\text { standards. SDDS data are posted on the BOT } \\
\text { website. The BOT also participated in the ROSC- } \\
\text { Data Module. BOT data meet the standards } \\
\text { related to coverage, periodicity, timeliness and } \\
\text { quality of economic data. }\end{array}$ \\
\hline
\end{tabular}




\begin{tabular}{|c|c|c|}
\hline Principle & Grading & Description \\
\hline $\begin{array}{l}3.2 \text { The central bank should publicly disclose its } \\
\text { balance sheet on a preannounced schedule and, } \\
\text { after a predetermined interval, publicly disclose } \\
\text { selected information on its aggregate market } \\
\text { transactions }\end{array}$ & $\mathrm{O}$ & $\begin{array}{l}\text { The Royal Decree requires that the BOT submit } \\
\text { to the MOF within three months after the end of } \\
\text { each financial year the balance sheet and the } \\
\text { income statement along with the report of the } \\
\text { CoD on the operations of the BOT throughout the } \\
\text { year. There are no other legal balance-sheet } \\
\text { publishing requirements. } \\
\text { However, in practice, publishing standards by the } \\
\text { BOT have been very high. The BOT publishes its } \\
\text { assets and liabilities every Friday with a one- } \\
\text { week lag on the BOT website. In addition, the } \\
\text { BOT publishes its annual balance sheet in the } \\
\text { Annual Economic Report by July following the } \\
\text { end of each financial year. High-frequency data } \\
\text { on BOT open market operations are posted } \\
\text { continually on the BOT website. Aggregated data } \\
\text { on selected items on market transactions are } \\
\text { published on the BOT website, the Quarterly } \\
\text { Bulletin and Annual Economic Report. }\end{array}$ \\
\hline $\begin{array}{l}3.3 \text { The central bank should establish and } \\
\text { maintain public information services. }\end{array}$ & $\mathrm{O}$ & $\begin{array}{l}\text { The BOT has established the Communications } \\
\text { and Relations Office to maintain the relationship } \\
\text { with external parties and oversee BOT's } \\
\text { publication program. In addition, the BOT has } \\
\text { established additional public information services } \\
\text { including the Public Information Room and the } \\
\text { Interactive Voice Response to provide the public } \\
\text { with financial and economic data. Finally, the } \\
\text { BOT provides copies of speeches, seminars, } \\
\text { research papers and has a publications program. }\end{array}$ \\
\hline $\begin{array}{l}\text { 3.4 Texts of regulations issued by the central } \\
\text { bank should be readily available to the public }\end{array}$ & $\mathrm{O}$ & $\begin{array}{l}\text { Regulations of the BOT and the summary of } \\
\text { important policies and measures are readily } \\
\text { available to the public - through BOT website } \\
\text { and the Annual Economic Report. }\end{array}$ \\
\hline $\begin{array}{l}\text { 4.1 Officials of the central bank should be } \\
\text { available to appear before a designated public } \\
\text { authority to report on the conduct of monetary } \\
\text { policy, explain the policy objective(s) of their } \\
\text { institution, describe their performance in } \\
\text { achieving their objective(s), and, as appropriate, } \\
\text { exchange views on the state of the economy and } \\
\text { the financial system }\end{array}$ & $\mathrm{O}$ & $\begin{array}{l}\text { The BOT officials regularly brief the Cabinet on } \\
\text { economic conditions and monetary } \\
\text { developments. Upon request, the BOT officials } \\
\text { appear before the relevant committees at the } \\
\text { Senate and the House of Representatives to report } \\
\text { on the conduct of monetary policy and exchange } \\
\text { views on the state of the economy and the } \\
\text { financial system. The BOT also appears before } \\
\text { market participants and the broader public to } \\
\text { explain the monetary policy and exchange rate } \\
\text { objectives, describe performance under the } \\
\text { inflation target framework, as well as BOT's } \\
\text { view of economic and financial sector } \\
\text { developments. }\end{array}$ \\
\hline
\end{tabular}




\begin{tabular}{|c|c|c|}
\hline Principle & Grading & Description \\
\hline $\begin{array}{l}\text { 4.2 The central bank should publicly disclose } \\
\text { audited financial statements of its operations on a } \\
\text { preannounced schedule }\end{array}$ & $\mathrm{BO}$ & $\begin{array}{l}\text { The BOT publishes its annual financial } \\
\text { statements reviewed by the Audit Committee and } \\
\text { audited by the Office of Auditor General of } \\
\text { Thailand by July following the end of the } \\
\text { financial year. The financial statements are } \\
\text { included in the Annual Economic Report. }\end{array}$ \\
\hline $\begin{array}{l}\text { 4.3 Information on the expenses and revenues in } \\
\text { operating the central bank should be publicly } \\
\text { disclosed annually }\end{array}$ & $\mathrm{O}$ & $\begin{array}{l}\text { Information on the expenses and revenues of the } \\
\text { BOT is publicly disclosed in its audited annual } \\
\text { financial statements in the Annual Economic } \\
\text { Report. }\end{array}$ \\
\hline $\begin{array}{l}\text { 4.4 Standards for the conduct of personal } \\
\text { financial affairs of officials and staff of the } \\
\text { central bank and rules to prevent exploitation of } \\
\text { conflicts of interest, including any general } \\
\text { fiduciary obligation, should be publicly disclosed }\end{array}$ & $\mathrm{BO}$ & $\begin{array}{l}\text { The BOT has code of conduct rules governing } \\
\text { personal financial affairs of BOT officials and } \\
\text { staff; rules to prevent exploitation of conflicts of } \\
\text { interest; and code of conduct rules for the MPC } \\
\text { members and BOT staff involved in the } \\
\text { preparation of MPC meetings. There is also an } \\
\text { internal regulation requiring BOT staff to report } \\
\text { the purchase/sale of securities by themselves or } \\
\text { their spouse to the BOT within } 15 \text { days after the } \\
\text { transaction date. Violations of these rules are } \\
\text { subject to sanctions. Directors of the CoD are } \\
\text { also required to report and disclose their personal } \\
\text { assets and liabilities to the National Counter } \\
\text { Corruption Commission. } \\
\text { The code of conduct rules do not include } \\
\text { disclosure for personal assets and liabilities for } \\
\text { BOT senior officials. The disclosure rule applies } \\
\text { only to Directors of the CoD. There are also no } \\
\text { rules requiring the declaration of interest by } \\
\text { directors, requirement for directors to refrain } \\
\text { from voting if they have interest in a decision and } \\
\text { the notation of such declaration in the minutes of } \\
\text { the BOT. }\end{array}$ \\
\hline
\end{tabular}

Table 11. Thailand: Recommended Action Plan to Improve Observance of the Transparency Code (Monetary Policy)

\begin{tabular}{|l|l|}
\hline \multicolumn{1}{|c|}{ Principle } & \multicolumn{1}{c|}{ Recommended Action } \\
\hline $\begin{array}{l}\text { 1.1.1 The ultimate objective(s) of monetary } \\
\text { policy should be specified in legislation and } \\
\text { publicly disclosed and explained. }\end{array}$ & $\begin{array}{l}\text { The primary objectives of monetary policy should be spelled } \\
\text { out in the BOT Act. }\end{array}$ \\
\hline
\end{tabular}




\begin{tabular}{|c|c|}
\hline Principle & Recommended Action \\
\hline $\begin{array}{l}\text { 1.1.3 The legislation establishing the central } \\
\text { bank should specify that the central bank has the } \\
\text { authority to utilize monetary instruments to } \\
\text { attain the policy objectives. }\end{array}$ & $\begin{array}{l}\text { The BOT should have full instrument flexibility and control } \\
\text { over its balance sheet to achieve the monetary objectives. The } \\
\text { BOT should be allowed to issue its own instrument without } \\
\text { prior approval of the MOF. The BOT should also be allowed } \\
\text { to pay interest on uncollateralized deposits within its standing } \\
\text { facility. }\end{array}$ \\
\hline $\begin{array}{l}\text { 1.1.6 If, in exceptional circumstances, the } \\
\text { government has the authority to override central } \\
\text { bank policy decisions, the conditions under } \\
\text { which this authority may be invoked and the } \\
\text { manner in which it is publicly disclosed should } \\
\text { be specified in legislation. }\end{array}$ & $\begin{array}{l}\text { The conditions for government intervention in the BOT's } \\
\text { affairs need to be spelled out and publicly disclosed, or, } \\
\text { otherwise Section } 14 \text { should be removed from the BOT Act to } \\
\text { enhance the transparency of BOT's operational independence. }\end{array}$ \\
\hline $\begin{array}{l}\text { 1.1.7 The procedures for appointment, terms of } \\
\text { office, and any general criteria for removal of the } \\
\text { heads and members of the governing body of the } \\
\text { central bank should be specified in legislation. }\end{array}$ & $\begin{array}{l}\text { The terms of office of the Governor and Deputy Governors } \\
\text { need to be specified in the BOT Act. }\end{array}$ \\
\hline $\begin{array}{l}\text { 1.2.3 The procedures for direct central bank } \\
\text { participation in the primary markets for } \\
\text { government securities, where permitted, and in } \\
\text { the secondary markets, should be publicly } \\
\text { disclosed. }\end{array}$ & $\begin{array}{l}\text { If the BOT intends to avail itself of the option to intervene in } \\
\text { the primary government securities market in the future, the } \\
\text { procedures for such participation should be clearly defined } \\
\text { (e.g., noncompetitive bids) and publicly disclosed. }\end{array}$ \\
\hline $\begin{array}{l}\text { 1.2.4 Central Bank involvement in the rest of the } \\
\text { economy should be conducted in an open and } \\
\text { public manner on the basis of clear practices and } \\
\text { procedures. }\end{array}$ & $\begin{array}{l}\text { The internally set overall credit ceiling on the BOT's financial } \\
\text { assistance program for the real sector should be disclosed as } \\
\text { well as the reasons for the setting of the overall ceiling. }\end{array}$ \\
\hline $\begin{array}{l}\text { 3.2.1 Summary central bank balance sheets } \\
\text { should be publicly disclosed on a frequent and } \\
\text { preannounced schedule. Detailed central bank } \\
\text { balance sheets prepared according to appropriate } \\
\text { and publicly documented accounting standards } \\
\text { should be publicly disclosed at least annually by } \\
\text { the central bank. }\end{array}$ & $\begin{array}{l}\text { The accounting standards applied (Thailand GAAP) should be } \\
\text { disclosed consistently in the BOT's Annual Economic Report. } \\
\text { The BOT should aim at producing annual audited } \\
\text { consolidated financial accounts that are consistent with its } \\
\text { monthly reporting on gross international reserves. To this end, } \\
\text { the Annual Economic Report would need to include the } \\
\text { audited balance sheet and income statement of the Issues } \\
\text { Department, the Currency Reserve and the Exchange } \\
\text { Equalization Fund. }\end{array}$ \\
\hline $\begin{array}{l}\text { 4.2.1 The financial statements should be audited } \\
\text { by an independent auditor. Information on } \\
\text { accounting policies and any qualification to the } \\
\text { statements should be an integral part of the } \\
\text { publicly disclosed financial statements. }\end{array}$ & $\begin{array}{l}\text { Qualifications with regard to the BOT's role in the FIDF } \\
\text { assistance, the financial assistance programs to the real sector } \\
\text { and the risk implications of these programs should be } \\
\text { described in greater detail in the Annual Economic Report. }\end{array}$ \\
\hline $\begin{array}{l}\text { 4.4 Standards for the conduct of personal } \\
\text { financial affairs of officials and staff of the } \\
\text { central bank and rules to prevent exploitation of } \\
\text { conflicts of interest, including any general } \\
\text { fiduciary obligations, should be publicly } \\
\text { disclosed. }\end{array}$ & $\begin{array}{l}\text { Disclosure rules should be set for personal assets and } \\
\text { liabilities for senior officials of the BOT. }\end{array}$ \\
\hline
\end{tabular}




\section{Authorities' response}

94. Recognizing the shortcomings in the legislation establishing the BOT in providing a clear monetary policy framework, the BOT has taken extensive efforts to close these gaps through an open and transparent framework for monetary policy decision-making and monetary policy operations. In many cases, the BOT has gone above and beyond the requirements that have been stipulated in legislation in order to achieve these goals, particularly in terms of data dissemination and information disclosure.

95. The BOT therefore welcomes the findings that monetary policy has been conducted in a transparent manner, which is crucial for the conduct of monetary policy under the inflation-targeting framework. The BOT also appreciates the recognition of the FSAP mission that such a high degree of transparency in formulating and reporting monetary policy has been the result of the BOT's continuous and extensive efforts to achieve these goals.

96. Given the importance of the legal framework underpinning transparent and credible monetary policy, the BOT has long been committed to addressing the remaining shortcomings in the legal framework with a view to defining the objectives of monetary policy as well as providing greater operational autonomy and accountability to the BOT. As acknowledged by the FSAP mission, the proposed amendment of the Bank of Thailand Act has already been approved in principle by the Cabinet. It is expected to be enacted by the Legislature within the term of this administration. Other key legislations are also in the pipeline.

97. The BOT is determined to take additional steps to further improve transparency in the conduct of monetary policy in areas identified in the assessment. However, with regard to the issue of publication of BOT's consolidated balance sheet and income statement, it is important to note that the Currency Reserve Account, as one of the components of the Issue Department, is wholly owned by the MOF, whereby the BOT is acting merely as a reserve manager. Therefore, a consolidated balance sheet and income statement, as recommended by the FSAP mission, would be neither practical nor appropriate.

Nevertheless, the balance sheets of Issue Department and Banking Department are already published on a weekly basis in the Royal Gazette and the BOT website. In this connection, the BOT recognizes that further clarification on this issue to the public will help increase our overall transparency. 


\section{Summary Assessment of Observance of Principles for Systemically Important Payment Systems}

\section{Systemically important payment systems (CPSS)}

98. The BAHTNET is a sound and efficient payment system and complies with the CPSS core principles for Systemically Important Payment Systems (CPSIPS). The system functionality is well developed, its risk management to mitigate credit and liquidity risks is adequate and its governance structure is affective and transparent. The legal basis to ensure settlement finality should further be strengthened. Some recommendations are provided in order to further enhance the operations of BAHTNET and its regulatory environment.

99. The summary assessment of compliance of BAHTNET with the CPSIPS was conducted in January 17-31, 2007. It was based on a comprehensive self-assessment, prepared by the BOT, and discussions with officials from relevant departments of the BOT, and with representatives of commercial banks and other financial institutions. During the discussions, complete information was received on the relevant laws, regulations, administrative polices and other technical and business aspects of the payment systems in Thailand. The methodology used for the assessment followed the Guidance Note prepared in August 2001.

\section{Institutional and market structure}

100. The BOT Act stipulates the roles of BOT in payment systems, including the issuance of bank notes and the operation of interbank clearing system. Based on this act, the BOT is empowered to issue regulations and guidelines on its payment services. The Payment Systems Committee (PSC) was set up in 2001, chaired by the Governor, with the aim of defining the BOT payment systems policy and oversight and promoting efficient payment systems and infrastructure in Thailand.

\section{The BOT owns and operates BAHTNET, System for Managing Automated} Retail Funds Transfer (SMART) and the Electronic Checks Clearing System (ECS). BAHTNET, which is a real time gross settlement (RTGS) system, is considered the only systemically important payment system in Thailand. It was modified in 2001 to allow for real time automated delivery versus payment (DVP) mechanism for the settlement of government securities. Payment transactions are processed and settled continuously and irrevocably in real-time. Final settlement of obligations between BAHTNET participants is executed through entries to their accounts at the books of BOT. The major bulk of BAHTNET payment transfers are channeled via SWIFT network and smaller amount of transactions are transmitted via BOT web-based platform. 
102. BAHTNET accepts payment instructions for interbank payments and for the settlement of net balances arising from low value payments systems such as ECS, SMART and Online Retail Funds Transfer system. BAHTNET also settles on a real time and gross basis the cash leg of the government securities transactions. In 2006, BAHTNET had 65 participants and the daily average value of transactions was B 595 billion and the volume was 7,220 transactions.

\section{There is no explicit legal provision that empowers the BOT to oversee the} payment systems. Its oversight responsibility is derived from its statutory responsibilities for monetary policy and banking supervision. Consequently, the BOT has the legal basis to oversee only payment systems operated by the commercial banks. However, a Royal Decree, which the Government expected to be enacted in 2007, would empower the BOT to regulate and oversee electronic payment services

\section{Main findings}

Well-founded legal basis (CP 1)

104. The current regulatory framework ensures that the design and operations of BAHTNET have a sound and solid legal basis. In particular, the relationship between the BOT and BAHTNET participants are based on contractual arrangements and enforced by laws. Although there is no zero hour rules in Thailand, it can not be ruled out that payment transactions settled in BAHTNET can be revoked in the event of insolvency. The Bankruptcy Law is currently being amended in order to address this issue.

\section{Understand and management of risks (CP 2 and 3)}

105. The BOT uses a variety of channels to ensure that participants understand BAHTNET business features, operational specifications and the risks they incur by using the system. Furthermore, the system's regulations identify the obligations and rights of the members and the system operator.

106. BAHTNET has adequate risk measures procedures in order to cope with credit and liquidity risks. It is an RTGS system with optimizing settlement functionality and queuing facility that settles in central bank money and allows access to liquidity from the central bank based on repo transactions. The BOT has well-established and adequate procedures to handle crisis situations.

Settlement (CP 4, 5, and 6)

107. BAHTNET settles in central bank money on a continuous basis during the day with intraday finality. The system provides prompt final settlement during the day although 
there is a potential risk that a transaction can be revoked in the event of insolvency. It is deemed that credit risk is negligible due to the lack of concentration of payments to few direct participants. Operating times are clearly defined and monitored.

\section{Operational reliability and efficiency (CP 7 and 8)}

108. BAHTNET activity and the payment process are monitored throughout the operating day and incidents and disruptions are logged adequately. Rules and routines are in place for operational follow up. The BOT has a contingency plan to cope with a wide range of incidents and failures. The system is protected from failures of technical infrastructure, services and natural disasters through redundancy at the primary site and duplication of services at the remote backup site. The contingency plan can be enhanced further by carrying out separate test specifically for BAHTNET, and requiring information on the testing result of the participants' internal payment systems.

109. As an RTGS system, BAHTNET meets the key requirements of speed, cost, practicality, and users' relevance. The system has an intra-day liquidity management arrangement, queuing facility and optimizing mechanism. At present, the BOT covers only BAHTNET operating cost, which is about 50 percent of the total cost. The BOT may consider reviewing its pricing policy taking into account the total cost as well as BAHTNET's benefit for the economy.

\section{Access and governance (CP 9 and 10)}

\section{BAHTNET system is open to banks other financial institutions and under} limited circumstances, nonbank government agencies. Its access criteria are clear, publicly disclosed, fair and objective. The governance arrangements are effective, accountable and transparent. BOT owns and manages the system. BAHTNET's participants are consulted on any major changes introduced to the system. However, the BOT may consider setting up an advisory user group that meets on a regular basis to discuss the system's technical and business features. BAHTNET fulfils the other nine CPSIPS.

\section{Central bank responsibilities (A-D)}

111. The BOT has a legal framework for its oversight activities for payment systems operated by commercial banks but not for systems operated by other institutions. The BOT objective (published in the Payment Systems Annual Report) is to promote sound and efficient payment systems in Thailand. The PSC was set up in order to advise the BOT in implementing its oversight responsibility and payment systems policy. The BOT Act is currently being revised to provide the legal basis for the BOT objective in the field of payment systems and the roles and responsibilities of the PSC. 
112. Within the Payment Systems Department there is a clear separation between the staff managing BAHTNET and those preparing the policy and oversight of the BOT. A formal assessment of BAHTNET against the Core Principles was carried out by the Payment Systems Policy and Oversight Office and the report was discussed by BOT executive management.

113. The BOT has set up a special office to oversee private sector payment systems. At present, there is no privately operated system in Thailand considered systemically important by the BOT.

114. The BOT cooperates with the SEC and other relevant authorities, and a MOU provides for information sharing. This cooperation can further be enhanced by having regular meetings between the BOT and the SEC. The BOT also cooperates with other central banks.

Table 12. Thailand: Summary of BAHTNET's Observance of CPSIPS

\begin{tabular}{|c|c|}
\hline Core Principle/Responsibility & Comments \\
\hline \multicolumn{2}{|l|}{ Legal foundation } \\
\hline $\begin{array}{l}\text { CP I - The system should have a well-founded } \\
\text { legal basis under all relevant jurisdictions. }\end{array}$ & $\begin{array}{l}\text { In general, the current regulatory framework ensures that } \\
\text { the design and operations of BAHTNET have a sound } \\
\text { and solid legal basis. }\end{array}$ \\
\hline \multicolumn{2}{|l|}{ Understand and management of risks } \\
\hline $\begin{array}{l}\text { CP II - The system's rules and procedures should } \\
\text { enable participants to have a clear understanding } \\
\text { of the system's impact on each of the financial } \\
\text { risks they incur through participation in it. }\end{array}$ & $\begin{array}{l}\text { A variety of channels are used aimed at ensuring that } \\
\text { participants understand BAHTNET business features, } \\
\text { operational specifications and the risks they incur by } \\
\text { using the system. }\end{array}$ \\
\hline $\begin{array}{l}\text { CP III - The system should have clearly defined } \\
\text { procedures for the management of credit risks } \\
\text { and liquidity risks, which specify the respective } \\
\text { responsibilities of the system operator and the } \\
\text { participants and which provide appropriate } \\
\text { incentives to manage and contain those risks. }\end{array}$ & $\begin{array}{l}\text { Adequate risk measures are in place in order to cope } \\
\text { with credit and liquidity risks. Furthermore, the BOT has } \\
\text { well-established and adequate procedures to handle } \\
\text { crisis situations. }\end{array}$ \\
\hline \multicolumn{2}{|l|}{ Settlement } \\
\hline $\begin{array}{l}\text { CP IV - The system should provide prompt final } \\
\text { settlement on the day of value, preferably during } \\
\text { the day and at a minimum at the end of the day. }\end{array}$ & $\begin{array}{l}\text { The system provides prompt final settlement during the } \\
\text { day. However, as mentioned above, there is a potential } \\
\text { risk that a transaction can be revoked in the event of } \\
\text { insolvency. }\end{array}$ \\
\hline
\end{tabular}




\begin{abstract}
CP V - A system in which multilateral netting takes place should, at a minimum, be capable of ensuring the timely completion of daily settlements in the event of an inability to settle by the participant with the largest single settlement obligation.
\end{abstract}

CP VI - Assets used for settlement should preferably be a claim on the central bank; where other assets are used, they should carry little or no credit risk and little or no liquidity risk.

\section{Operational reliability and efficiency}

CP VII - The system should ensure a high degree of security and operational reliability and should have contingency arrangements for timely completion of daily processing.

CP VIII - The system should provide a means of making payments, which is practical for its users and efficient for the economy.

\section{Access and governance}

CP IX - The system should have objective and publicly disclosed criteria for participation, which permit fair and open access.
Not applicable, as BAHTNET is a gross settlement system.
BAHTNET settles in central bank money on a continuous basis during the day with intraday finality.
Several measures are in place in order to ensure a high degree of security and operational reliability, including redundancy at the primary site and duplication of services at the remote backup site.

BAHTNET meets the key requirements of speed, cost, practicality, and users' relevance.
CP X - The system's governance arrangements should be effective, accountable and transparent.
BAHTNET access criteria are clear, publicly disclosed, fair and objective. These criteria do not have a restrictive impact on competition. Rules relating to suspension, termination and resignation from BAHTNET are also defined in BAHTNET regulations.

BAHTNET governance arrangements are effective, accountable and transparent.

The BOT's objective, which is published in the Payment Systems Annual Report and other relevant materials, is to promote sound and efficient payment systems in Thailand. The PSC was set up in order to advise the BOT in implementing its oversight responsibility and payment systems policy.

A formal assessment of BAHTNET against the Core Principles was carried out by the Payment Systems Policy and Oversight Office and the report was discussed by BOT executive management.

At present, there is no privately operated system in Thailand considered systemically important by the BOT to be assessed.
Responsibility C - The central bank should oversee observance with the core principles by systems it does not operate and it should have the ability to carry out this oversight. 
Responsibility D - The central bank, in promoting payment system safety and efficiency through the core principles, should cooperate with other central banks and with any other relevant domestic or foreign authorities.
The BOT cooperates with the SEC and other relevant authorities. A Memorandum of Understanding for sharing information is set up with the SEC and the Department of Insurance. The BOT also cooperates with other central banks, in particular, in neighboring countries, to exchange experience and knowledge on payment systems issues.

Table 13. Thailand: Recommended Actions to Improve BAHTNET's Observance of CPSIPS and the BOT Responsibilities in Applying the CPs

\begin{tabular}{|c|c|}
\hline Reference Principle & Recommended Action \\
\hline Legal foundation (CP I) & $\begin{array}{l}\text { While the opinion provided by the official of the Council } \\
\text { of State helps to eliminate the risk that payment } \\
\text { transactions settled in BAHTNET and securities } \\
\text { transactions settled in TSD can be revoked in the event of } \\
\text { insolvency, it would be better to amend the Bankruptcy } \\
\text { Law in order to provide greater certainty in this regard. }\end{array}$ \\
\hline Settlement finality (CP IV) & $\begin{array}{l}\text { While the opinion provided by the official of the Council } \\
\text { of State helps to eliminate the risk that payment } \\
\text { transactions settled in BAHTNET can be revoked in the } \\
\text { event of insolvency, it would be better to amend the } \\
\text { Bankruptcy Law in order to provide greater certainty in } \\
\text { this regard. }\end{array}$ \\
\hline $\begin{array}{l}\text { Security and operational reliability, and } \\
\text { contingency arrangements (CP VII) }\end{array}$ & $\begin{array}{l}\text { Extend the scope of external audit of BAHTNET } \\
\text { IT-infrastructure to include internal procedures and } \\
\text { routines for business continuity. } \\
\text { Carry out a separate contingency test specifically for } \\
\text { BAHTNET. } \\
\text { Request BAHTNET participants, including TSD, to } \\
\text { submit the summary of the contingency plan test and the } \\
\text { results of regular external audits of the security of their } \\
\text { internal payment infrastructure. }\end{array}$ \\
\hline $\begin{array}{l}\text { Efficiency and practicality of the system } \\
\text { (CP VIII) }\end{array}$ & $\begin{array}{l}\text { Revise the methodology used to determine the pricing } \\
\text { structure taking into account the total cost as well as the } \\
\text { benefit for the entire economy such as systemic risk } \\
\text { reduction. }\end{array}$ \\
\hline Governance of the payment system (CP X) & $\begin{array}{l}\text { Set up a permanent advisory user group that meets on a } \\
\text { regular basis to discuss issues related to technical and } \\
\text { business features of BAHTNET. }\end{array}$ \\
\hline
\end{tabular}




\begin{tabular}{|l|l|}
\hline \multicolumn{1}{|c|}{ Reference Principle } & \multicolumn{1}{|c|}{ Recommended Action } \\
\hline Central Bank Responsibilities in Applying the & $\begin{array}{l}\text { Enact the revised BOT Act that would provide more } \\
\text { transparency of the BOT objectives in the field of } \\
\text { payment systems. } \\
\text { Avoid potential conflicts of interest between the BOT } \\
\text { oversight function and its role as an operator of } \\
\text { BAHTNET when formalizing the PSC's function and } \\
\text { responsibilities. } \\
\text { Strengthen the BOT oversight responsibility by further } \\
\text { developing its oversight methodology and procedures, } \\
\text { including prioritization among payment systems, selection } \\
\text { of the oversight instruments to be used and the periodicity } \\
\text { of onsite inspection of systemically important systems. } \\
\text { Strengthen the cooperation with SEC by having regular } \\
\text { meetings to discuss common issues, including the } \\
\text { operations of TSD and its interaction with BAHTNET. }\end{array}$ \\
\hline
\end{tabular}

\section{Authorities' response}

115. BOT agreed with the assessment and appreciated to have had Thailand's systemically important payment system, the BOT BAHTNET, reviewed by the IMF and the FSAP. The review was conducted professionally and cooperatively.

116. With regard to the recommendation to have explicit legal protection for settlement finality in both BAHTNET and securities settlement system, the Bankruptcy Law has already been in the process of amendment. It is to ensure that transactions in BAHTNET cannot be revoked by the court order in the event of insolvency of the participant.

117. As BOT is at the initial stage of implementing payment systems oversight, some necessary steps are needed to broaden the area of oversight. Currently, BOT is formalizing the oversight methodology and procedures.

\section{E. Recommendations for Securities Settlement Systems}

\section{The assessment of TSD against the CPSS/IOSCO/RSSS demonstrates that the} system to a large extent is sound, efficient and reliable. However, essential measures need to be introduced in order to strengthen the legal soundness of the system, enhance its governance, improve its communication network and increase transparency of the system. In particular, the netting arrangements should be legally valid even in the event of bankruptcy. The settlement and depository functions of TSD need to be protected from the credit and liquidity risks inherent in the CCP function. In addition, there is a potential conflict of interest between providing CCP and CSD services as the former one may obligate 
participants to use its CCP service in order to have access to CSD functions. The most effective way to avoid a conflict of interest is to legally separate the CSD and the CCP functions. To reduce the settlement risk, TSD should refrain from allowing debit balances of securities. TSD settlement and custody fees are bundled into the total fees charged by the SET. TSD should have its own pricing structure and regularly review its pricing levels against its costs of operation. Adequate regulatory and oversight frameworks should be put in place which would allow the SEC to exercise its' regulatory tasks, and allow the BOT to exercise its' oversight responsibilities effectively. Cooperation between the SEC and the BOT should be substantially strengthened.

\section{Information and methodology}

119. Assessment of the securities settlement system was undertaken in May 2007. Prior to the mission, the SEC conducted a self-assessment. The Thailand authorities were fully cooperative. The mission also benefited from meetings with market participants. The assessment covers TSD as the CSD and the settlement system for a broad range of securities, such as equities, government bonds and corporate bonds traded both on regulated markets and OTC. The assessment does not cover the CCP function of TSD. This function should be assessed against the CPSS/IOSCO recommendations for central counterparty, which covers broader aspects of CCP activities.

\section{Institutional and market structure}

120. The securities markets in Thailand are relatively well developed. The size of the equity market was US $\$ 112$ billion at the end of 2006, equivalent to 51 percent of GDP and the number of listed companies amounted to 518. The annual turnover value for 2006 was US $\$ 111$ billion. The debt market is relatively large in Thailand. At the end of 2006, the outstanding value of government bonds and bills was US $\$ 41.45$ billion (18.81 percent of GDP) and US $\$ 6.43$ billion (2.92 percent of GDP), respectively. Apart from government bonds, the outstanding value of state-owned enterprise bonds was US\$9.39 billion and US\$4.46 billion for government guaranteed and nongovernment guaranteed issues, respectively. As for state agency bonds, the outstanding value was US\$25.29 billion. Most corporate bonds were issued domestically in private placement with an outstanding value of US $\$ 23.98$ billion. The total trading value at 2006 year-end was recorded at US $\$ 120$ billion with an average daily trading value of US\$496 million.

\section{The SET, established by a $\mathbf{1 9 7 4}$ law is the only authorized regulated securities}

market. It began trading operations before the establishment of SEC. In 1998, the Market for Alternative Investment was established as a business unit of the SET to open up fund-raising opportunities for small and medium-sized enterprises. TSD, a wholly owned subsidiary of the SET, is the only clearinghouse and central securities depository in Thailand. It provides central securities depository and settlement functions for equities, government and corporate 
bonds, bills of exchange, investment units and warrants. TSD also acts as a CCP for equities. Members include securities companies, commercial banks, custodian banks, finance companies, BOT, and certain institutional investors such as insurance companies, financial institutional or juristic persons established by specific laws.

122. The SEC, established in 1992 under the SEA, is responsible for regulating securities businesses in Thailand. The SEC is empowered to supervise and develop the primary and secondary markets. The SEC is authorized to regulate and supervise securities clearing and settlement systems, but for historical reasons, the TSD is exempt from being regulated by the SEC. Currently, the BOT does not have any active role in overseeing the clearing and settlement activities of the TSD.

\section{Main findings}

\section{Legal framework (Rec. 1)}

123. The regulatory framework provides some legal protection for the operations of TSD. The business relationship between TSD and its participants is based on contractual arrangements, enforced by laws, but there is uncertainty whether the netting arrangement is legally protected in the event of the insolvency of a participant.

\section{Pre-settlement risk (Rec. 2-5)}

124. All trades between direct market participants are confirmed the same day and are settled three days after trade execution for equities, and two days for debt instruments. Technological improvements need to be introduced to the system before further shortening the settlement cycle.

125. TSD acts as a CCP for securities listed on the SET. No cost-benefit analysis has been carried out to introduce CCP for debt instruments. Issues related to the regulation of CCP, risk management, financial strength and efficiency are covered by the CPSS/IOSCO Recommendations for CCP and, therefore, the SEC is encouraged to assess TSD against these Recommendations.

126. There is a securities lending and borrowing mechanism in place, but lending activity is very low. Allowing nonresidents to participate in the local securities lending market would contribute to its development and enhance the liquidity in the securities market. 
Settlement risk (Rec. 6-10)

127. Securities are issued in a physical form and a relatively high share of them are immobilized. Moving towards dematerialized securities regime - where the issuance and transfer of securities take place in a book entry form-would significantly reduce the cost of settlement and custody, and improve the efficiency of the securities market. TSD has adequate risk control procedures to address participants' failure to settle, including calling for full collateralization of exposures that exceed a predetermined limit. However, due to the lack of a same-day buy-in facility, the TSD ends up permitting debit balances in equities.

\section{Operational risk (Rec. 11)}

128. TSD has adequate procedures and processes to monitor, identify, and manage operational risk. Issues related to operational risk are handled by senior managers and checked by the Managing Director. Written documentation is in place to handle different contingency scenarios. A "live" secondary site is in place that allows the resumption of operations within a short period of time in the event of any malfunction of the primary site. The TSD business continuity plan, including a back-up facilities system, is subject to both internal and external audit.

\section{Custody risk (Rec. 12)}

129. Several technical and institutional arrangements are in place to ensure the protection of the customers' securities. Participants are obligated to segregate their assets from those of customers, and to reconcile the securities held in their records, they need to carry out internal audits on a regular basis.

\section{Other issues (Rec. 13-19)}

130. TSD access criteria are objective and permit fair and open access to all financial intermediaries. The TSD may open its system to foreign participants after implementing the appropriate risk management procedures. TSD uses a proprietary network to send and receive instructions that does not fully meet international procedures and standards. TSD rules and other contractual arrangements defining the rights and obligations of the participants are publicly available. The SEC intends to publish the answers to key question in RSSS methodology on its website. In order to influence the design and operation of TSD, SEC needs to rely on the SET. TSD is not subject to the oversight responsibility of the BOT. An MOU between the SEC and the BOT for sharing information on the relevant prudential issues and to address financial disruption has not yet been implemented. 


\section{Table 14. Thailand: Summary of Observance of the RSSS-ROSCs}

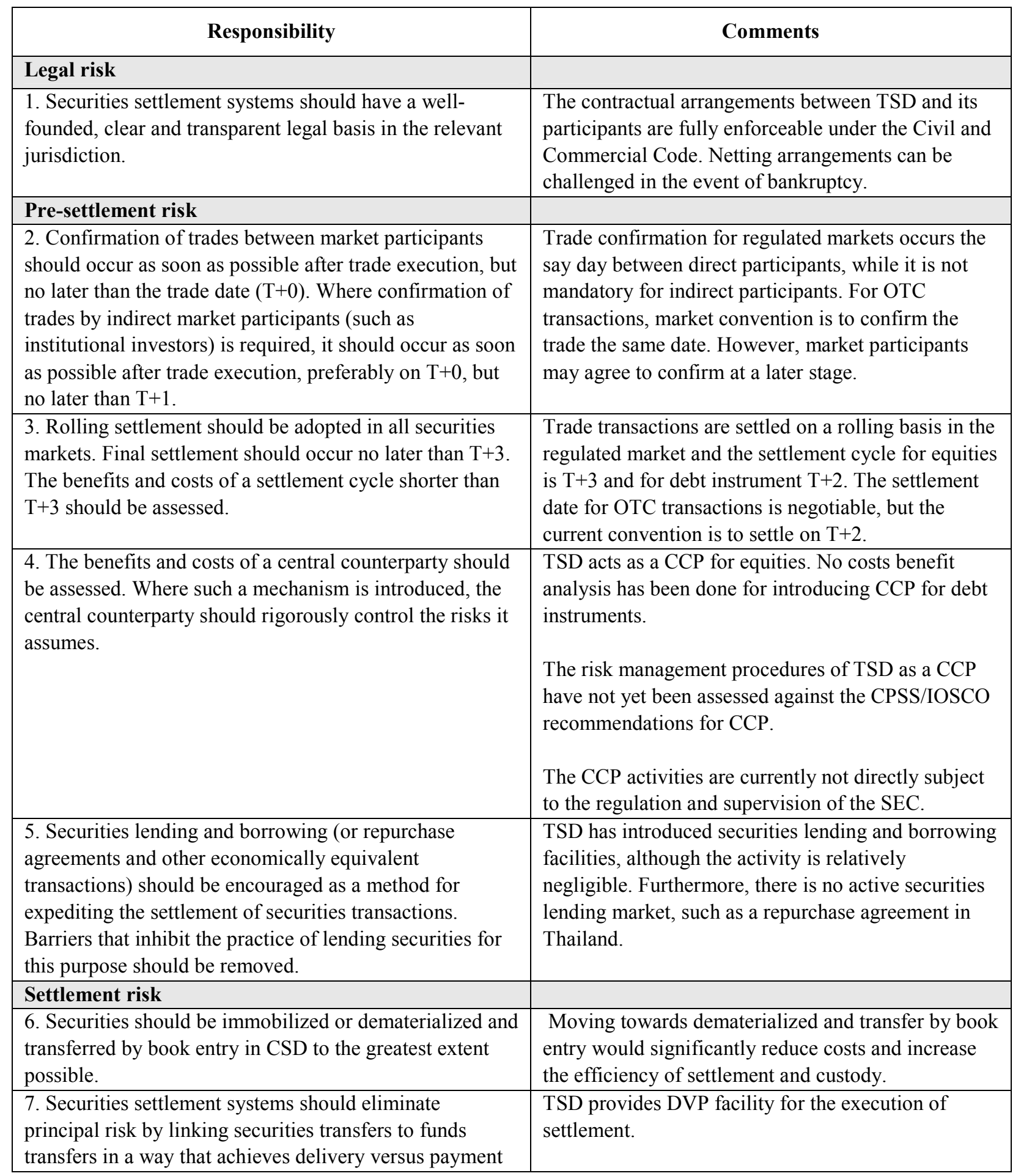




\begin{tabular}{|c|c|}
\hline Responsibility & Comments \\
\hline $\begin{array}{l}\text { 8. Final settlement on a DVP basis should occur no later } \\
\text { than the end of the settlement day. Intra-day or real-time } \\
\text { finality should be provided where necessary to reduce } \\
\text { risks. }\end{array}$ & $\begin{array}{l}\text { TSD provides both intraday and end-of-day } \\
\text { settlement finality. }\end{array}$ \\
\hline $\begin{array}{l}\text { 9. CSDs that extend intraday credit to participants, } \\
\text { including CSDs that operate net settlement systems, } \\
\text { should institute risk controls that, at a minimum, ensure } \\
\text { timely settlement in the event that the participant with the } \\
\text { largest payment obligation is unable to settle. The most } \\
\text { reliable set of controls is a combination of collateral } \\
\text { requirements and limits. }\end{array}$ & $\begin{array}{l}\text { TSD permits debit balances in securities. This means } \\
\text { securities which have not yet been delivered to the } \\
\text { system are booked on the accounts of the } \\
\text { participants. } \\
\text { In addition, the CSD functions-registration, } \\
\text { settlement and custody - are integrated with the CCP } \\
\text { function of TSD. This means that CSD is exposed to } \\
\text { the principle risk inherited in CCP activities. As best } \\
\text { practice, the CCP function is separated from the CSD } \\
\text { functions, and the former one is provided by a } \\
\text { distinct legal entity. }\end{array}$ \\
\hline $\begin{array}{l}\text { 10. Assets used to settle the cash leg of securities } \\
\text { transactions between CSD members should carry little or } \\
\text { no credit risk. If Central Bank money is not used, steps } \\
\text { must be taken to protect CSD members from potential } \\
\text { losses and liquidity pressures arising from the failure of a } \\
\text { settlement bank. }\end{array}$ & $\begin{array}{l}\text { The cash leg of the transactions is settled in central } \\
\text { bank money. However, the settlement risk is } \\
\text { concentrated in the three major banks. }\end{array}$ \\
\hline \multicolumn{2}{|l|}{ Operational risk } \\
\hline $\begin{array}{l}\text { 11. Sources of operational risk arising in the clearing and } \\
\text { settlement process should be identified and minimized } \\
\text { through the development of appropriate systems, controls } \\
\text { and procedures. Systems should be reliable and secure, } \\
\text { and have adequate, scalable capacity. Contingency plans } \\
\text { and back-up facilities should be established to allow for } \\
\text { timely recovery of operations and completion of the } \\
\text { settlement process. }\end{array}$ & $\begin{array}{l}\text { TSD has adequate measures in place in order to } \\
\text { identify and monitor operational risk. It also has } \\
\text { developed a contingency plan that ensures the system } \\
\text { can resume on short notice and the information can } \\
\text { be retrieved. The procedures are tested on a regular } \\
\text { basis and market participants are involved in the } \\
\text { testing. }\end{array}$ \\
\hline \multicolumn{2}{|l|}{ Custody risk } \\
\hline $\begin{array}{l}\text { 12. Entities holding securities in custody should employ } \\
\text { accounting practices and safekeeping procedures that } \\
\text { fully protect customers' securities. It is essential that } \\
\text { customers' securities be protected against the claims of a } \\
\text { custodian's creditors. }\end{array}$ & $\begin{array}{l}\text { Adequate measures and arrangements are in place to } \\
\text { ensure the protection of the customers' securities. In } \\
\text { particular, the regulation of TSD obliges the } \\
\text { participants to segregate their assets from those of } \\
\text { the customers and reconciliation is done on a regular } \\
\text { basis. }\end{array}$ \\
\hline \multicolumn{2}{|l|}{ Other issues } \\
\hline $\begin{array}{l}\text { 13. Governance arrangements for CSDs and central } \\
\text { counterparties should be designed to fulfill public interest } \\
\text { requirements and to promote the objectives of owners and } \\
\text { users. }\end{array}$ & $\begin{array}{l}\text { SET appoints the majority of the TSD board and } \\
\text { defines its policy and objectives. SET has also the } \\
\text { power to specify the issues, conditions and } \\
\text { procedures of TSD. This creates a conflict of interest, } \\
\text { as the interest of SET may not be compatible with } \\
\text { that of TSD, which also provides settlement and } \\
\text { custody services to non trading members. }\end{array}$ \\
\hline
\end{tabular}




\begin{tabular}{|c|c|}
\hline Responsibility & Comments \\
\hline $\begin{array}{l}\text { 14. CSDs and central counterparties should have } \\
\text { objectives and publicly disclosed criteria for participation } \\
\text { that permit fair and open access. }\end{array}$ & $\begin{array}{l}\text { The access and exit criteria are clearly defined and } \\
\text { publicly disclosed. TSD accepts only direct } \\
\text { participants located in Thailand. This is justified by } \\
\text { the need to limit the system's exposure to the risks } \\
\text { associated with cross-border activities. }\end{array}$ \\
\hline $\begin{array}{l}\text { 15. While maintaining safe and secure operations, } \\
\text { securities settlement systems should be cost-effective in } \\
\text { meeting the requirements of users. }\end{array}$ & $\begin{array}{l}\text { TSD's settlement and custody fees are integrated in } \\
\text { the aggregated fees collected by the parent company, } \\
\text { SET. These fees cover trading, clearing, settlement } \\
\text { and custody services. Consequently, TSD is not able } \\
\text { to benchmark its prices against other CSDs in the } \\
\text { region. TSD service levels are reviewed annually by } \\
\text { surveying users. }\end{array}$ \\
\hline $\begin{array}{l}\text { 16. Securities settlement systems should use or } \\
\text { accommodate the relevant international communication } \\
\text { procedures and standards in order to facilitate efficient } \\
\text { settlement of cross-border transactions. }\end{array}$ & $\begin{array}{l}\text { TSD uses proprietary communication network for } \\
\text { securities listed on the SET. This network does not } \\
\text { offer a high level of data transfer protection and the } \\
\text { data can be converted into international standards } \\
\text { with considerable difficulty. For government bonds, } \\
\text { Society for Worldwide Interbank Financial } \\
\text { Telecommunication (SWIFT) message is used. }\end{array}$ \\
\hline $\begin{array}{l}\text { 17. CSDs and central counterparties should provide } \\
\text { market participants with sufficient information for them } \\
\text { to accurately identify the risks and costs associated with } \\
\text { using the CSD or central counterparty services. }\end{array}$ & $\begin{array}{l}\text { Laws, regulations, systems' rules, and fees are part of } \\
\text { the contractual agreements that are to be signed by } \\
\text { participants. In particular, participants' rights, } \\
\text { obligations and costs are defined in these } \\
\text { agreements, which are also available on the TSD } \\
\text { website. } \\
\text { TSD has publicly disclosed the questionnaire set out } \\
\text { in the CPSS/IOSCO disclosure framework. }\end{array}$ \\
\hline $\begin{array}{l}\text { 18. Securities settlement systems should be subject to } \\
\text { regulation and oversight. The responsibilities and } \\
\text { objectives of the securities regulator and the central bank } \\
\text { with respect to RSSSs should be clearly defined, and their } \\
\text { roles and major policies should be publicly disclosed. } \\
\text { They should have the ability and resources to perform } \\
\text { their responsibilities, including assessing and promoting } \\
\text { implementation of these recommendations. They should } \\
\text { cooperate with each other and with other relevant } \\
\text { authorities. }\end{array}$ & $\begin{array}{l}\text { The SEC lacks the legal power to regulate and } \\
\text { supervise TSD. However, through its regulation of } \\
\text { the stock exchange, the SEC has the possibility to } \\
\text { influence the design and operation of TSD. } \\
\text { TSD is not subject to the oversight responsibility of } \\
\text { the BOT. } \\
\text { The cooperation between the SEC and BOT is not } \\
\text { fully effective. }\end{array}$ \\
\hline $\begin{array}{l}\text { 19. CSDs that establish links to settle cross-border trades } \\
\text { should design and operate such links to reduce effectively } \\
\text { the risks associated with cross-border settlement. }\end{array}$ & TSD has not established links to foreign CSDs. \\
\hline
\end{tabular}


Table 15. Thailand: Recommended Action Plan to Improve Observance of the RSSS

\begin{tabular}{|c|c|}
\hline Reference Recommendation & Recommended Action \\
\hline Legal risk (Rec. 1) & $\begin{array}{l}\text { Adequate legal measures should be implemented as soon as } \\
\text { possible to ensure that the netting arrangement is legally } \\
\text { protected even in the event of the insolvency of a participant. }\end{array}$ \\
\hline Pre-settlement risk (Rec. 2-5) & $\begin{array}{l}\text { A cost-benefit analysis should be carried out aimed at assessing } \\
\text { whether CCP should be introduced for debt instruments } \\
\text { transactions. } \\
\text { As an immediate measure, the CCP activities should be subject } \\
\text { to the regulation and supervision of the SEC. } \\
\text { SEC is encouraged to assess the CCP function of TSD against } \\
\text { the CPSS/IOSCO Recommendations for CCP. }\end{array}$ \\
\hline Settlement risk (Rec. 6-10) & $\begin{array}{l}\text { SEC together with the BOT should explore the possibility to } \\
\text { develop a regulatory framework for dematerialized securities } \\
\text { TSD should not credit the participants' securities accounts until } \\
\text { the settlement is final. } \\
\text { In order to protect the CSD from any contagious risk inherent in } \\
\text { CCP activities, it should consider separating the CCP function } \\
\text { from the CSD function, by setting up a distinct legal entity that } \\
\text { provides CCP services. }\end{array}$ \\
\hline Operational risk (Rec. 9) & $\begin{array}{l}\text { SEC should receive a copy of the internal and external audit of } \\
\text { TSD policy and procedures to handle operational risk. }\end{array}$ \\
\hline Custody risk (Rec. 12) & $\begin{array}{l}\text { SEC and BOT should cooperate in order to ensure that custodian } \\
\text { banks are implementing the necessary measures to protect the } \\
\text { customer's assets. }\end{array}$ \\
\hline Other issues (Rec. 13-18) & $\begin{array}{l}\text { The TSD may consider opening its system to foreign } \\
\text { participants. } \\
\text { In order to eliminate the risk of cross-subsidizing and increase } \\
\text { transparency, the pricing structure of TSD should be separated } \\
\text { from that of the stock exchange and TSD should have in place } \\
\text { procedures to regularly review its pricing levels against costs } \\
\text { of operation. }\end{array}$ \\
\hline
\end{tabular}




\begin{tabular}{|c|c|}
\hline Reference Recommendation & Recommended Action \\
\hline & $\begin{array}{l}\text { The Governance structure of TSD should be strengthened by } \\
\text { appointing more independent board members and by not being } \\
\text { subject to the "regulation power" of the Board of SET. } \\
\text { TSD should enhance its proprietary network to meet } \\
\text { international procedures and standards. } \\
\text { SEC should have the legal power to directly regulate and } \\
\text { supervise TSD without the involvement of the Board of SET. } \\
\text { The BOT should assume its oversight responsibility of TSD } \\
\text { and should set put a dedicated team to oversee the activities of } \\
\text { TSD. } \\
\text { The SEC and BOT should develop a cooperation framework } \\
\text { that identifies the responsibility of each authority, aimed at } \\
\text { avoiding overlapping and loopholes. This framework should } \\
\text { specify clearly the tasks of each authority, areas where both } \\
\text { authorities have common interests, exchange of information, } \\
\text { etc. For instance and in line with international experience, the } \\
\text { BOT would be responsible for the containment of systemic } \\
\text { risk and the soundness of clearing and settlement systems, } \\
\text { while SEC would be responsible for the proper conduct, } \\
\text { protection of investors, governance, access and transparency. } \\
\text { In order to increase the effectiveness of their cooperation and } \\
\text { strengthening their overall supervision and oversight roles, the } \\
\text { SEC and the BOT need to increase their mutual } \\
\text { understandings of respective regulatory objectives and needs. } \\
\text { SEC and BOT should enhance the capacity of their staff by } \\
\text { setting up dedicated teams to deal with securities clearing and } \\
\text { settlement systems. The members of these teams should be } \\
\text { offered specific courses, seminars and on-job training. }\end{array}$ \\
\hline
\end{tabular}

\section{Authorities' response}

\section{The results of FSAP assessment on Thailand's securities settlement system against the CPSS/IOSCO recommendations reflect a highly satisfactory level of compliance, which in turn can serve as an assurance that Thailand's securities settlement system is on par with international best practices. Major weaknesses} identified, which involve coverage of SEC supervisory power over the TSD, and efficiency in the TSD's risk management and operations, will be attended to promptly. In particular, the TSD is committed to abolishing debit balances and implementing a same day buy-in and 
same day settlement facility upon participants' failure by the end of this year. In response to the recommendation to separate the $\mathrm{CCP}$ function from the depository function to prevent conflict of interest and any risk impact on securities depositors, the SEC is in the process of requesting a technical assistance from the IMF to conduct a study on this matter. To increase transparency in the TSD's pricing/cost structure and reduce the risk of cross subsidizing since the TSD's settlement and custody fees are currently included in the aggregate fees collected by its parent company, the SET, the TSD is reviewing its cost structure and in the process of unbundling its fees.

132. The SEC is aware of the limitation in its legal power to directly regulate and supervise the TSD (without going through the Board of the SET). A draft amendment to the SEA had been proposed, passed the scrutiny of the Council of State, and was pending endorsement of the National Assembly. The proposed amendment, when effective, would give the SEC the power to directly regulate the TSD.

\section{F. Summary Assessment of Observance of the Financial Action Task Force Recommendations for Anti-Money Laundering and Combating the Financing of Terrorism}

\section{Introduction}

133. This Report on the Observance of Standards and Codes for the FATF 40 Recommendations 2003 for AML and 9 Special Recommendations on CFT were prepared using the AML/CFT Methodology 2004 and were carried out as part of a separate mission to Thailand from February 26 to March 13, 2007. ${ }^{15}$ The report provides a summary of the AML/CFT measures in place in Thailand, the level of compliance with the FATF 40+9 Recommendations, and contains recommendations on how the AML/CFT system could be strengthened. The Detailed Assessment Report (DAR) on which this document is based was approved by the Asia-Pacific Group (APG) on Money Laundering plenary and agreed by the Thailand authorities.

\section{Executive summary}

134. Thailand has introduced a number of measures in recent years to strengthen its AML/CFT framework, particularly for CFT. The regime has resulted in a very large number of suspicious transaction reports, a large amount of assets being seized, and contributed to the Thailand government's objective of tackling drug crime. These

\footnotetext{
${ }^{15}$ The assessment team consisted of: Stephen Dawe (Legal Department (LEG), team leader); Giuseppe Lombardo (LEG); Pierre-Laurent Chatain (World Bank) and Mariano Federici and Tom Hansen (experts under LEG supervision). Mr. Hansen also participated as an observer from the APG.
} 
achievements occurred despite outmoded legislation and other shortcomings identified in the DAR.

135. Thailand is susceptible to money laundering (ML) and terrorist financing (TF) because illicit proceeds are generated from drug trafficking, illegal gambling, theft, prostitution, human trafficking, illegal logging, corruption and from crime in bordering countries and because of a terrorist problem in its southern region. The illegal economy in Thailand has been estimated up to 13 percent of GDP and with ML predicate offenses estimated to generate illicit proceeds of up to five percent of GDP. In addition, the widespread use of cash and a large informal sector, estimated at up to 53 percent of GDP, provide many avenues for illicit proceeds to be laundered in Thailand.

136. Thailand has a legal framework in the 1999 AMLA, around which the core elements of its AML/CFT regime are established. The AMLA criminalizes ML by reference to eight predicate offenses, establishes the AMLO as Thailand's financial intelligence unit (FIU), imposes some customer due diligence (CDD) obligations on a wide range of financial institutions (FIs), requires these FIs to report transactions to the AMLO, and creates a civil process for the AMLO to seize criminal assets and have them vested in the state.

137. However, the AML/CFT framework is not fully in line with international standards and codes - there are weaknesses in the legal framework, the pursuit of ML cases, the coverage of institutions and in enforcement. The recommendations to address these include:

- $\quad$ amending the AMLA in order to: (i) properly criminalize ML so that it covers all serious domestic predicate offenses; (ii) impose the core AML/CFT obligations to all FIs that contain ML and TF risks; and (iii) clarify AML/CFT supervisory roles and give appropriate powers for conducting compliance examinations;

- $\quad$ strengthening enforcement when the AMLO and the financial regulators discover breaches of AML/CFT obligations;

- $\quad$ extending AML/CFT obligations to nonfinancial businesses and professions;

- $\quad$ properly pursuing criminal investigations and prosecutions of ML and TF; and

- $\quad$ fully implementing the UN Security Council Resolutions and properly criminalizing TF 
138. The authorities are committed to bringing Thailand's AML/CFT regime up to international standards and they are supported in this endeavor by the management of the major FIs.

\section{Legal systems and related institutional measures}

139. Money laundering in Thailand is criminalized under the AMLA, but not fully in accordance with the FATF recommendations. The predicate offenses in the AMLA need to be extended to cover all serious offenses and, at a minimum, the 14 out of the 20 designated categories of offenses in the FATF 40+9 recommendations not currently covered.

140. The AMLO is also established under the AMLA to carry out the FIU, and other functions. Critically, the AMLO disseminates few reports to Thailand's law enforcement agencies (LEAs) for completion of criminal investigations and prosecution of ML offenses due to the operational tendency of AMLO to focus on civil seizure cases. Moreover, the AMLO does not allocate sufficient resources to properly analyze the suspicious transactions reports (STRs) it receives. AMLO's structure includes an investigative unit that focuses on seizing assets under a civil process for vesting property in the State. The unit is not an LEA, but it does work with LEAs to help pursue its civil process, and assists in their criminal cases. Insufficient effort has been put into providing guidelines, feedback, and public awareness about ML and TF.

141. While the use of civil processes has resulted in a large amount of criminal assets being seized, the authorities need to place more emphasis on pursuing criminal investigations and prosecutions for ML and TF. Total asset seizures in Thailand since 1999 exceed US\$250 million. The AMLO has seized approximately US\$30 million of assets each year and secured permanent vesting of approximately US\$14 million per year under its civil processes. The AMLO and LEAs have preferred to pursue criminal assets using civil processes because the standard of proof is lower than in criminal prosecutions, and because they have been encouraged by the existence of rewards for staff based on the amount of assets seized. The AMLO rewards system is in the process of being abolished partly because it acts as a disincentive for the AMLO to focus on its core FIU role, and partly for integrity reasons. On average, Thailand prosecutes just eight ML cases each year, obtaining convictions for three of those. The prosecuted cases typically relate to self-laundering connected with drug offenses and not other predicate offenses.

142. Most law enforcement agencies need to provide more training on, and dedicate specialized staff to carry out, ML or TF investigations, especially outside of Bangkok. The exception would be the Office of the Narcotics Control Board (ONCB) Asset Forfeiture Group who have, over the last several years, successfully prosecuted cases and forfeited assets associated with drug trafficking. Investigators attached to this unit have been trained and have provided proceeds of crime training to other police agencies involved in narcotics 
investigations throughout the country. Further, the AMLO has trained over 800 Royal Thailand Police (RTP) officers across Thailand on financial investigations. Even though that training focused on civil processes to seize property, the officers were provided specialized training in investigative techniques that they can apply to criminal investigations.

143. Financing of terrorism is criminalized under the Penal Code and is a predicate offense for ML under the AMLA, but not fully in accordance with international standards. The Penal Code offense of TF needs amendment to: extend to the financing of the acts set forth in the treaties in the annex of the UN TF Convention; fully cover the individual terrorist or terrorist organization; cover the mere provision or collection of property to a terrorist or terrorist organization; and, to increase the sanctions for the offense of TF. Moreover, the authorities do not appear to place sufficient reliance on investigating TF to deal with Thailand's significant domestic terrorism issues, and no TF cases have been prosecuted to date.

\section{Preventive measures-financial institutions}

144. The Thailand legal framework for preventive measures for FIs consists of the AMLA, ministerial regulations and other secondary legislation, and guidelines issued by supervisory authorities. In the Thailand system, the secondary legislation and guidelines issued by supervisory authorities are referred to as "Notifications" (sometimes circular letters) or "Policy Statements." Notifications can be considered as regulations or other enforceable means depending on the method of issue and their content. In some instances, notifications may have the status of unenforceable guidelines.

145. Imposing preventive measures in the financial sector is hampered by outdated legislation, a diverse range of institutions, and a lack of clarity about which agencies are responsible for regulating and supervising the institutions that are subject to AML/CFT obligations.

146. There is a limited range of preventive measures applying to the FIs contained in the AMLA, and regulations made pursuant to it, which apply to the most important types of FI in Thailand. FIs must have their customers identify themselves when they conduct certain transactions. Under the AMLA, FIs are required to report to the AMLO: a) cash transactions over B 2 million (US\$52,800); b) transactions connected with property worth more than B 5 million (US\$132,000); and, c) suspicious transactions, regardless of the amount of the transaction. The reporting system results in approximately 40,000 STRs each year, almost all from banks. However, there are issues that need to be addressed to improve the AMLA: a) Customer identification does not extend to beneficial ownership, applies only to transactions that must be reported, and there is no obligation to conduct ongoing due diligence of the business relationship, including monitoring transactions; b) The threshold for occasional transactions of B 2 million (US\$53,000) exceeds the US\$15,000 amount 
permitted by the standard and cannot be justified compared to the average Thailand income level of US\$3,000; and c) There is no requirement to report attempted transactions, and only limited guidance has been issued by the authorities to help FIs identify suspicious transactions.

\section{The AMLA also does not require enhanced scrutiny of transactions involving} countries which do not, or insufficiently, apply the FATF Recommendations, and Thailand has no mechanism to apply counter-measures against such countries. Finally, the AMLA does not apply to all FIs that operate in Thailand - a notable omission being authorized money transfer agents. All FIs that carry out financial activities in Thailand, as defined in the FATF 40+9 Recommendations glossary, should be subjected to AML/CFT requirements under the AMLA covering all the core obligations, unless their exclusion can be justified on the basis of a robust risk assessment relating to their activities. The authorities should consider conducting such an assessment — which would also help in developing and implementing a risk-based approach to supervision of FIs for AML/CFT.

148. The authorities are aware of the latest FATF $40+9$ Recommendations and the limitations of the AMLA. The core agencies, (the AMLO, the BOT and the SEC have been enthusiastically and diligently taking steps aimed at bringing Thailand's practice into better compliance with the FATF 40+9 Recommendations by supplementing the AMLA with other measures. However, inadequate and outdated laws hamper their efforts. Often they have had to rely on their good relations with and the goodwill of industry to implement measures that may not be in laws or regulations or are not otherwise enforceable. For example, in March 2007 the AMLO issued a Policy Statement on Compliance with the Know Your Customer and CDD for FIs and Designated Nonfinancial Businesses and Professions (DNFBPs) (the AMLO Policy Statement) containing unenforceable preventive measures. The BOT has issued a number of guidelines that are based on moral suasion and cooperation from FIs.

149. The result is that many of the AML/CFT preventive measures that exist are not enforceable for the purposes of the FATF $40+9$ recommendations, including most of those that apply to banks, which dominate the financial sector. The securities sector has the highest level of compliance with the formal requirements of the FATF 40+9

Recommendations. The management of the main banks, securities firms, and insurance companies met showed a good awareness of ML and TF risks and a willingness to implement measures to mitigate such risks even in the absence of legal obligations. However, the newness of many of the measures coupled with the need for the authorities to issue detailed guidance meant that, at the time of the mission, most institutions were still in the process of implementing the latest requirements.

150. The BOT regulates money services businesses, however, substantive measures are still needed to mitigate their ML and TF risks. Authorized money transfer agents should be made subject to the full range of AML/CFT obligations and the competent 
authorities should increase their efforts to suppress illegal money changing and remittance activity in the large informal sector. Contrary to the FATF standard, there is no law, regulation or other enforceable means regulating wire transfers. There are no declaration or disclosure requirements applying to cross-border transportation of foreign currency, bearer instruments, or the import of domestic currency, and the few controls that are in place are insufficient to effectively mitigate the known risks that exist.

151. The AMLO and the financial regulators have increased their supervision and monitoring of AML/CFT requirements in recent years but there is still room for improvement. There has not been a clear designation of which competent authorities are responsible for ensuring that FIs comply with the AMLA, and some institutions are not subject to any supervision for their AML/CFT obligations. The BOT and the SEC (but not the Department of Insurance) carry out effective AML/CFT monitoring of the FIs that they supervise. Both the BOT and SEC, however, operate under legislation that makes it complicated to impose sanctions for non-compliance. Moreover, greater consideration should be given to imposing criminal sanctions for significant breaches of the AMLA by FIs.

152. The amendments to the AMLA should also clearly delineate the roles of the AMLO and the financial supervisors for monitoring compliance with AML/CFT requirements, and give appropriate powers for conducting compliance examinations. The AMLO and the financial regulators should also establish effective MOUs for coordinating their efforts and sharing information. The authorities should raise awareness about ML and TF among FIs and improve the provision of guidance, especially aimed at the detection of suspicious transactions.

\section{Preventive measures—designated nonfinancial businesses and professions}

153. There are no AML/CFT requirements in place in relation to any categories of the DNFBPs. Moreover, while it is illegal for casinos to operate in Thailand, many illegal casinos do exist. Thailand needs to determine how to apply AML/CFT requirements to each of the DNFBPs before the necessary amendments are made to the AMLA and other laws.

\section{Legal persons and arrangements \& nonprofit organizations}

154. The corporate registry system in Thailand contains information, updated annually, about legal, but not beneficial, ownership of juristic persons. Consideration should be given to improving the provision of beneficial ownership information-including mechanisms to identify beneficial owners of bearer shares, which, even though permitted, no companies have issued them.

155. Thailand has begun a review of the adequacy of existing laws and regulations that relate to nonprofit organizations that can be abused for TF. That review should be 
completed and appropriate steps taken to mitigate any potential terrorism risks that the review identifies.

\section{National and international co-operation}

156. The AMLA establishes the Anti-Money Laundering Board (AMLB) which has a role in overseeing the AMLO's operations and coordinating AML/CFT issues in Thailand, with representation from a wide range of government agencies. However, improvements are needed to ensure that the AMLB operates effectively to develop, implement, and monitor Thailand's overall AML/CFT regime. The AMLO, as the central agency with responsibility for implementing the AMLA, did not maintain, and also had difficulty obtaining, some key information and statistics about ML/TF in Thailand. Moreover, many officials, particularly those outside of law enforcement, appeared to have a narrow view that ML relates mainly to narcotics using cash.

157. Thailand has signed, but not ratified, the Palermo Convention and has not fully implemented the Vienna Convention or the UN Terrorist Financing Convention. These deficiencies should be remedied as soon as possible. Thailand should also implement specific measures to ensure that terrorist property can be frozen without delay, as required under United Nations Security Council Resolutions 1267 and 1373.

158. The AMLO has been a member of the Egmont Group of FIUs since 2001 and has a track record of exchanging information with other foreign FIUs. Thailand authorities have also enjoyed success in apprehending international criminals - notably, arresting the terrorist known as Hanbali. It should be noted, however, that the narrow range of predicate offenses for ML and deficiencies in the TF offense in Thailand also seriously impede the ability of Thailand to cooperate internationally on ML and TF matters.

\section{Other issues}

159. The authorities should give higher priority to reduce cash use and encourage more activity to come within the formal sector to help reduce ML and TF risks.

160. The AMLO compiles a lot of statistical information about the country's AML/CFT regime and publishes some related information in its annual report, but there is room for improvement. Steps should be taken to improve data collection and statistics on ML investigations, prosecutions, and convictions, foreign assistance requests, and results relating to ML or TF investigations, and terrorist and TF activities.

161. There are good intentions and efforts of the authorities to bring Thailand into compliance with the FATF 40+9 Recommendations can only be achieved once the 
legislation that they are using to operate Thailand's AML/CFT regime is amended to address the deficiencies identified in the DAR.

\section{Table 16. Thailand: Prioritized Key Recommendations to Improve the AML/CFT System}

\begin{tabular}{|c|c|}
\hline $\begin{array}{c}\text { FATF 40+9 Recommendations and } \\
\text { Rating }{ }^{16}\end{array}$ & $\begin{array}{l}\text { Key Assessor Recommendations } \\
\text { (In order of priority within each section) }\end{array}$ \\
\hline \multicolumn{2}{|l|}{ 1. General } \\
\hline \multicolumn{2}{|l|}{$\begin{array}{l}\text { 2. Legal System and Related } \\
\text { Institutional Measures }\end{array}$} \\
\hline $\begin{array}{l}\text { Criminalization of Money Laundering } \\
\text { (R. 1, 2 - Rating: PC, LC) }\end{array}$ & $\begin{array}{l}\text { - Amend the AMLA to extend the predicate offences to cover all } \\
\text { serious offences, or all categories of offences, under the FATF } 40+9 \text {. } \\
\text { - Undertake more criminal prosecutions. } \\
\text { - Amend the AMLA to make it absolutely clear that the offence of ML } \\
\text { can be committed when any of the predicate offences take place } \\
\text { outside of Thailand. } \\
\text { - Improve statistics on ML investigations, prosecutions and } \\
\text { convictions. }\end{array}$ \\
\hline $\begin{array}{l}\text { Criminalization of Terrorist Financing } \\
\text { (SR.II - Rating: PC) }\end{array}$ & $\begin{array}{l}\text { - Amend the Thailand Penal Code to make the TF conduct consistent } \\
\text { with Thailand's obligations under SR. II; to extend the TF offence to } \\
\text { cover in all circumstances the provision or collection of funds for } \\
\text { individual terrorists or terrorist organizations; to remove } \\
\text { requirements that providing or collecting funds be for the purpose of } \\
\text { committing a terrorist act or as part of a terrorist plan; and to } \\
\text { increase the sanctions for legal persons committing TF. } \\
\text { Improve statistics on TF investigations. }\end{array}$ \\
\hline $\begin{array}{l}\text { Confiscation, Freezing, and Seizing of } \\
\text { Proceeds of Crime } \\
\text { (R. } 3 \text { - Rating: LC) }\end{array}$ & $\begin{array}{l}\text { Amend the law to enable the identification of, tracing of, and the } \\
\text { voiding of actions that prejudice the recovery of tainted property. } \\
\text { Expand the Penal Code forfeiture provisions to deal with property } \\
\text { derived from the proceeds of crime. } \\
\text { - Improve consultation between the RTP, Department of Special } \\
\text { Investigation (DSI), AMLO, and the ONCB regarding whether cases } \\
\text { or asset seizures should be pursued civilly or criminally. } \\
\text { Pursue the obtaining of final forfeiture and vesting orders more } \\
\text { rigorously. }\end{array}$ \\
\hline $\begin{array}{l}\text { Freezing of Funds used for Terrorist } \\
\text { Financing }\end{array}$ & $\begin{array}{l}\text { Improve legislation and/or procedures to enable the freezing of } \\
\text { terrorist funds or other assets of terrorists without delay. }\end{array}$ \\
\hline
\end{tabular}

\footnotetext{
${ }^{16}$ Compliant (C): the Recommendation is fully observed with respect to all essential criteria. Largely compliant (LC): there are only minor shortcomings, with a large majority of the essential criteria being fully met. Partially compliant (PC): the country has taken some substantive action and complies with some of the essential criteria. Non-compliant (NC): there are major shortcomings, with a large majority of the essential criteria not being met. Not applicable (NA): a requirement or part of a requirement does not apply, due to the structural, legal or institutional features of a country e.g., a particular type of financial institution does not exist in that country.
} 


\begin{tabular}{|c|c|}
\hline (SR. III - Rating: PC) & $\begin{array}{l}\text { Establish effective procedures for considering de-listing requests and } \\
\text { unfreezing the funds of de-listed persons or entities in a timely } \\
\text { manner. } \\
\text { Establish procedures for authorizing access to property seized or } \\
\text { attached that is necessary for basic expenses, the payment of certain } \\
\text { types of fees, expenses and service charges, or for ordinary } \\
\text { expenses. } \\
\text { - Establish measures to monitor FI compliance with relevant } \\
\text { legislation, rules, or regulations concerning the freezing and } \\
\text { confiscation of terrorist property. }\end{array}$ \\
\hline $\begin{array}{l}\text { The Financial Intelligence Unit and Its } \\
\text { Functions } \\
\text { (R. 26 - Rating: PC) }\end{array}$ & $\begin{array}{l}\text { - Amend the AMLA so that the AMLO has specific authority to } \\
\text { disseminate financial analysis to domestic competent authorities for } \\
\text { investigation where ML or TF is suspected and carry out more } \\
\text { dissemination. } \\
\text { - Effectively abolish the AMLO "rewards system." } \\
\text { - Issue comprehensive guidelines for FIs about reporting suspicious } \\
\text { transactions reports (STRs). } \\
\text { - Publish information about ML trends and typologies in a more } \\
\text { timely manner. } \\
\text { - Establish a separate unit within the AMLO for compliance } \\
\text { monitoring. } \\
\text { - Improve the integrity of AML/CFT statistics produced by the } \\
\text { AMLO. } \\
\text { Increase the AMLO's budget and consider creating an asset } \\
\text { forfeiture fund (or similar) to help fund the increase. } \\
\text { Consider recruiting the AMLO staff with financial sector expertise. }\end{array}$ \\
\hline $\begin{array}{l}\text { Law Enforcement, Prosecution and } \\
\text { Other Competent Authorities } \\
\text { (R. 27, 28 - Rating: PC, LC) }\end{array}$ & $\begin{array}{l}\text { Commit resources in the LEAs and National Counter Corruption } \\
\text { Commission, including outside of Bangkok, to undertake ML/TF } \\
\text { financial investigations during all predicate offence cases. } \\
\text { - Increase training across Thailand on ML, financial investigations } \\
\text { and investigating TF cases for police and prosecutors. } \\
\text { - Improve statistics on predicate offence charges, asset seizures and } \\
\text { forfeitures. } \\
\text { - Develop closer relationships between LEAs and the AMLO. } \\
\text { - Consider locating some DSI TF trained investigators in the south of } \\
\text { Thailand to work closer with officials investigating terrorism } \\
\text { incidents. } \\
\text { - Publish trends and typologies relating to ML and TF cases. }\end{array}$ \\
\hline $\begin{array}{l}\text { Cross Border Declaration or } \\
\text { Disclosure } \\
\text { (SR. IX - Rating: NC) }\end{array}$ & $\begin{array}{l}\text { - Expand the declaration/disclosure requirements to all circumstances } \\
\text { set forth by SR. IX and extend it to "bearer negotiable instruments." } \\
\text { - Provide the Customs authorities with the power to stop, restrain, } \\
\text { freeze and confiscate currency or bearer negotiable instruments, } \\
\text { other proceeds of crime, and funds where there is a suspicion of ML } \\
\text { or TF activity. } \\
\text { - Improve cooperation and information exchange between Customs } \\
\text { and the AMLO. } \\
\text { - Create sanctions for cross-border transportation of currency related } \\
\text { to ML/TF. }\end{array}$ \\
\hline
\end{tabular}




\begin{tabular}{|c|c|}
\hline $\begin{array}{l}\text { 3. Preventive Measures-Financial } \\
\text { Institutions }\end{array}$ & \\
\hline $\begin{array}{l}\text { Customer Due Diligence, Including } \\
\text { Enhanced or Reduced Measures } \\
\text { (R. 5, 6,7,8-Rating: All NC) }\end{array}$ & $\begin{array}{l}\text { - Make each FI as defined in the FATF } 40+9 \text { glossary subject to the } \\
\text { AMLA or justify each exclusion based on a robust risk assessment. } \\
\text { - Amend the AMLA to fully incorporate the FATF CDD } \\
\text { requirements. } \\
\text { - Introduce enforceable requirements so that all FIs must carry out } \\
\text { enhanced due diligence for higher risk customers, business } \\
\text { relationships, or transactions. } \\
\text { - Conduct a ML/FT risk assessment for the categories of transactions } \\
\text { - } \text { exempted from the requirements in the AMLA. } \\
\text { - Pedraft existing guidelines and policy statements concerning } \\
\text { Introduce enforceable obligations for all FIs to have policies and } \\
\text { procedures to address risks from new technologies or nonface to face } \\
\text { business. }\end{array}$ \\
\hline $\begin{array}{l}\text { Third Parties and Introduced Business } \\
\text { (R.9- Rating: NC) }\end{array}$ & $\begin{array}{l}\text { - Issue enforceable obligations consistent with Recommendation } 9 \text { for } \\
\text { circumstances where the use of third party introducers is permitted. }\end{array}$ \\
\hline $\begin{array}{l}\text { Financial Institution Secrecy or } \\
\text { Confidentiality } \\
\text { (R. } 4 \text { - Rating: C) }\end{array}$ & \\
\hline $\begin{array}{l}\text { Record Keeping and Wire Transfer } \\
\text { Rules } \\
\text { (R. 10, SR.VII - Rating: PC, NC) }\end{array}$ & $\begin{array}{l}\text { - Amend the AMLA to require all FIs to keep records and } \\
\text { identification data for all transactions. } \\
\text { - Regulate wire transfers in accordance with the requirements of SR. } \\
\text { VII. }\end{array}$ \\
\hline $\begin{array}{l}\text { Monitoring of Transactions and } \\
\text { Relationships } \\
\text { (R. 11, 21 - Rating: PC, NC) }\end{array}$ & $\begin{array}{l}\text { - Require all FIs to pay special attention to complex, unusual large } \\
\text { transactions, or unusual patterns of transactions and record their } \\
\text { findings in writing. } \\
\text { - Introduce measures to deal with countries which do not or } \\
\text { insufficiently apply the FATF Recommendations. }\end{array}$ \\
\hline $\begin{array}{l}\text { Suspicious Transaction Reports and } \\
\text { Other Reporting } \\
\text { (R. 13, 14, 19, 25, SR.IV - Rating: } \\
\text { PC, PC, C, PC, PC) }\end{array}$ & $\begin{array}{l}\text { Expand reporting requirements to all FIs as defined by the FATF } \\
\text { Glossary. } \\
\text { - Introduce an obligation to report attempted transactions. } \\
\text { Evaluate the ML/FT risk for transactions for which reporting is } \\
\text { exempted. } \\
\text { - Provide more guidance to FIs on how to detect suspicious } \\
\text { transactions. } \\
\text { - Prohibit "tipping off," and modify or delete section } 21 \text { of the } \\
\text { AMLA. } \\
\text { - Give more feedback to FIs about the STRs that have been reported. }\end{array}$ \\
\hline $\begin{array}{l}\text { Internal Controls, Compliance, Audit } \\
\text { and Foreign Branches } \\
\text { (R. 15, 22 - Rating: PC, NC) }\end{array}$ & $\begin{array}{l}\text { Require FIs to develop programs against ML and TF and to apply } \\
\text { AML/CFT measures to foreign branches and subsidiaries. }\end{array}$ \\
\hline $\begin{array}{l}\text { Shell Banks } \\
\text { (R. 18 - Rating: PC) }\end{array}$ & - $\quad$ Prohibit Thailand's FIs from dealing with shell banks. \\
\hline $\begin{array}{l}\text { The Supervisory and Oversight } \\
\text { System-Competent Authorities and } \\
\text { SROs } \\
\text { Role, Functions, Duties and Powers }\end{array}$ & $\begin{array}{l}\text { - Impose sanctions against FIs that breach AML/CFT requirements. } \\
\text { - Conduct an assessment of the AML/CFT risks in the financial sector. } \\
\text { - Ensure that all FIs without a proven low-risk of ML or TF are } \\
\text { effectively regulated and supervised or monitored for compliance }\end{array}$ \\
\hline
\end{tabular}




\begin{tabular}{|c|c|}
\hline $\begin{array}{l}\text { (including sanctions) } \\
\text { (R. 17, 23, 25, 29, 30 - Rating: All } \\
\text { PC) }\end{array}$ & $\begin{array}{l}\text { with AML/CFT. } \\
\text { - Strengthen regulation, supervision and enforcement of remittance } \\
\text { activity. } \\
\text { - Strengthen the measures in place to prevent criminals owning FIs. }\end{array}$ \\
\hline $\begin{array}{l}\text { Money Value Transfer Services } \\
\text { (SR. VI - Rating: PC) }\end{array}$ & $\begin{array}{l}\text { - Make all money transfer agents subject to the full range of FATF } \\
\text { Recommendations applicable to them. } \\
\text { - Take further efforts to suppress illegal remittance activities. } \\
\text { - Investigate the illegal remittance flows to determine what } \\
\text { improvements are needed to the framework governing remittance } \\
\text { businesses. }\end{array}$ \\
\hline $\begin{array}{l}\text { 4. Preventive Measures- } \\
\text { Nonfinancial Businesses and } \\
\text { Professions }\end{array}$ & \\
\hline $\begin{array}{l}\text { Customer Due Diligence and Record- } \\
\text { keeping } \\
\text { (R. } 12 \text { - Rating: NC) }\end{array}$ & $\begin{array}{l}\text { - Assess the ML and TF risks that apply in each of the DNFBPs. } \\
\text { Decide how to apply AML/CFT requirements to each of the } \\
\text { DNFBPs and then make necessary amendments to the AMLA and } \\
\text { other laws. } \\
\text { - Carry out awareness raising with each of the DNFBPs. }\end{array}$ \\
\hline $\begin{array}{l}\text { Suspicious Transaction Reporting } \\
\text { (R. 16- Rating: NC) }\end{array}$ & - Amend the AMLA to introduce an STR regime for DNFBPs \\
\hline $\begin{array}{l}\text { Regulation, Supervision, Monitoring, } \\
\text { and Sanctions } \\
\text { (R. } 24 \text { \& 25 - Rating: Both NC) }\end{array}$ & - Introduce a regulatory and supervisory framework for DNFBPs. \\
\hline $\begin{array}{l}\text { Other Designated Nonfinancial } \\
\text { Businesses and Professions } \\
\text { (R. 20 - Rating: PC) }\end{array}$ & $\begin{array}{l}\text { - Strengthen efforts to bring more financial activity within the formal } \\
\text { sector. } \\
\text { - } \\
\text { Encourage more use of noncash payment methods. }\end{array}$ \\
\hline $\begin{array}{l}\text { 5. Legal Persons and Arrangements } \\
\text { \& Nonprofit Organizations }\end{array}$ & \\
\hline $\begin{array}{l}\text { Legal Persons-Access to Beneficial } \\
\text { Ownership and Control Information } \\
\text { (R. 33 - Rating: PC) }\end{array}$ & $\begin{array}{l}\text { Require more information on beneficial ownership/control to be } \\
\text { available. } \\
\text { Introduce measures to ensure that bearer shares are not misused for } \\
\text { ML. }\end{array}$ \\
\hline $\begin{array}{l}\text { Nonprofit Organizations (NPO) } \\
\text { (SR. VIII - Rating: NC) }\end{array}$ & $\begin{array}{l}\text { - Undertake a review of the adequacy of laws and regulations that } \\
\text { relate to NPO that can be abused for the financing of terrorism. } \\
\text { - Carry out outreach with the NPO sector about TF abuse. } \\
\text { Improve financial recordkeeping, supervision and monitoring of the } \\
\text { NPOs with significant financial resources. } \\
\text { Designate an official contact point for foreign requests for NPO } \\
\text { information. }\end{array}$ \\
\hline \multicolumn{2}{|l|}{$\begin{array}{l}\text { 6. National and International } \\
\text { Cooperation }\end{array}$} \\
\hline $\begin{array}{l}\text { National Cooperation and } \\
\text { Coordination (R. } 31 \text { - Rating: PC) }\end{array}$ & $\begin{array}{l}\text { - Clearly designate an agency responsible for Thailand's AML/CFT } \\
\text { policies. } \\
\text { Review which agencies are represented at the AMLB and, if } \\
\text { necessary, amend the AMLA to ensure that there is appropriate } \\
\text { coverage. } \\
\text { Encourage the authorities to share more information amongst } \\
\text { themselves concerning compliance by FIs of their AML/CFT } \\
\text { responsibilities. }\end{array}$ \\
\hline
\end{tabular}




\begin{tabular}{|l|ll|}
\hline $\begin{array}{l}\text { The Conventions and UN Special } \\
\text { Resolutions } \\
\text { (R. 35, SR.I - Rating: Both PC) }\end{array}$ & $\begin{array}{l}\text { - } \\
\text { Ratify the Palermo Convention. } \\
\text { Amend the Act on Mutual Assistance in Criminal Matters to limit } \\
\text { the application of section 9(3) of the Act relating to political } \\
\text { offenses; }\end{array}$ \\
& $\begin{array}{l}\text { Amend the TF offense as previously indicated. } \\
\text { Enact specific laws or procedures to freeze terrorist funds without } \\
\text { delay. }\end{array}$ \\
\hline $\begin{array}{l}\text { Mutual Legal Assistance } \\
\text { (R. 36, 37, 38, SR.V - Rating: All } \\
\text { PC) }\end{array}$ & $\begin{array}{l}\text { Amend the ML predicate offenses and the TF offenses as previously } \\
\text { indicated. }\end{array}$ \\
& $\begin{array}{l}\text { Amend the law to enable the rendering of assistance where the } \\
\text { request relates to property of corresponding value. }\end{array}$ \\
\hline $\begin{array}{l}\text { Extradition } \\
\text { (R. 39, 37, SR.V - Rating: All PC) }\end{array}$ & $\begin{array}{l}\text { Improve statistics on Mutual Legal Assistance Treaty (MLAT) } \\
\text { requests, seizures, and types of offences involved. }\end{array}$ \\
& $\begin{array}{l}\text { Amend the Extradition Act to improve the process for prosecuting } \\
\text { Thailand nationals where their extradition for a ML offence has been } \\
\text { denied. }\end{array}$ \\
\hline $\begin{array}{l}\text { Other Forms of Cooperation } \\
\text { (R. 40, SR.V - Rating: LC, PC) }\end{array}$ & $\begin{array}{l}\text { Amend the ML predicate offenses and the TF offense as previously } \\
\text { indicated. }\end{array}$ \\
\hline 7. Other issues & $\begin{array}{l}\text { Demonstrate that international cooperation mechanisms are fully } \\
\text { effective. }\end{array}$ \\
\hline $\begin{array}{l}\text { Resources and Statistics } \\
\text { (R. 30 \& 32 - Rating: Both PC) }\end{array}$ & $\begin{array}{l}\text { Improve statistics in the following areas: ML investigations, } \\
\text { prosecutions and convictions; TF investigations; predicate offence } \\
\text { charges; asset seizures and forfeitures; and, MLAT requests, } \\
\text { seizures, and types of offences involved. }\end{array}$ \\
\hline
\end{tabular}

\section{Authorities' response}

162. While the overall assessment in the DAR is found to be acceptable, there are some crucial areas where Thailand authorities find wanting further explanation. These are:

- With regard to Legal System and Related Institutional Measures. Thailand has listed eight predicate offenses of money laundering in Section 3 of the AML law, and the authorities are now in the legislation process to extend the list to include eight additional categories of offenses. The Government has adopted a policy of abolishing the reward system. Upon the abolishment, an Asset Fund will be set up to make available resources in support of the AMLO's functions and AML/CFT activities.

- With regard to Preventive Measures Related to Financial Institutions, the AMLA and other regulations already contain key elements cited in Section 3 of the DAR as requirements for an effective regulatory and supervisory system. By virtue of the AMLA 1999 and other enabling laws, the AMLO and the other competent authorities have the power to issue guidance, guidelines notifications, or regulations that are legally binding on regulated entities. 
- With regard to National and International Cooperation, the AMLO has entered, as of July 17, 2007, into MOUs with 31 foreign FIUs concerning cooperation in the exchange of financial intelligence related to ML. Thailand actively provides cooperation upon receiving requests from other countries where ML investigations are involved. Thailand has also entered into a number of MOUs with other countries, which extend beyond criminal matters to defense and intelligence cooperation.

- $\quad$ On the domestic front, the AMLO has entered into MOUs with domestic law enforcement agencies and other agencies in relation to the investigation of ML, the seizure and forfeiture of assets, the prosecution of ML, and the conduct of civil forfeiture cases by prosecutors from the Attorney General's Office.

163. Thailand can assure the world community that (1) Thailand has an AML/CFT regime for almost eight years now, functioning effectively, (2) Thailand's mutual legal assistance and international cooperation record is a matter of high praise by the foreign counterparts, (3) Thailand's asset forfeiture regime is operating to the benefit of the State, and (4) Thailand's enthusiasm for bringing about a more effective and efficient AML/CFT system is truly appreciated by the world community. 


\section{APPENDIX I: MAIN DEVELOPMENTS SINCE THE 1997 FINANCIAL CRISIS}

\section{Thailand experienced a costly financial sector crisis a decade ago (Box 3 ).} The crisis, which extended for several years, highlighted underlying balance sheet vulnerabilities in the financial and corporate sectors and weaknesses in the legal and regulatory framework governing the financial system. It also underscored the systemic importance of the banking sector. In total, the authorities estimate the gross fiscal cost of the crisis was equivalent to 33 percent of 2006 GDP. ${ }^{17}$

\section{Considerable progress has been made since then to strengthen the resilience of} the economy and the financial sector. Macroeconomic management has significantly improved, with the move to a managed floating exchange rate, the adoption of an inflation targeting framework, and the enhanced transparency of monetary policy. Inflation has declined to the lowest level in decades, and has been kept within the BOT's target range of 0-3.5 percent; interest rates have fallen; credit to the private sector has revived; and the exchange rate has strengthened from its low levels at end-1997. Along with robust economic growth and the implementation of a fiscal sustainability framework, which established a number of fiscal rules, the public debt burden has fallen to sustainable levels. At the same time, large current account surpluses helped halve the external debt burden. International reserves have increased sharply since the crisis to now over US\$80 billion, despite full repayment of the official financial support package, and sovereign risk premia are at a historical low.

\section{Weaknesses in the regulatory and supervisory framework for banks have largely} been addressed. Prudential rules and regulations have been generally brought in line with international standards and overall banking supervision has significantly improved. Risk management guidelines have been issued and brought into the BOT's supervisory framework; onsite and offsite supervision has been strengthened and upgraded; and a bankby-bank early warning system has been put in place. There has been considerable improvement in data collection and analysis of prudential indicators. Unfortunately, shortcomings in the framework that are outside the control of the BOT and which require legislative action, have not yet been addressed.

167. Initiatives have been undertaken to deepen and broaden the capital markets and strengthen corporate governance framework. ${ }^{18}$ These efforts were generally successful in broadening and deepening the capital markets, and increasing their share in the economy, which is reflected in the doubling of the size of the bond market since the crisis.

\footnotetext{
${ }^{17}$ This excludes cost recoveries through liquidation, assets sales, and sales of equity stakes in the intervened banks.

${ }^{18}$ Thailand completed an assessment of its corporate governance framework by the World Bank in 2005.
} 


\section{Box 3. Thailand: 1997 Financial Crisis and Crisis Management Framework}

After more than a decade of high economic growth, Thailand's financial sector experienced a major crisis in mid-1997, unprecedented in scope and magnitude. Under increasing pressure and following ineffective interventions and dwindling international reserves, the baht was floated on July 2, 1997. Several years of strong economic growth, underwritten by rapid credit expansion and large capital inflows, masked underlying structural weaknesses in the balance sheet of corporate and financial institutions, which were not addressed by the supervisors. Finance companies were the first to be affected by the rapidly worsening conditions, which then spread to the commercial banks. In mid-1997, the government suspended the operations of 58 out of 91 finance companies, accounting for about 12.5 percent of the financial sector. Fifty-six of these were closed by end-1997.

Significant balance of payments assistance from the international community and considerable fiscal assistance to address the problems in the financial sector ensued. Several emergency decrees were passed in October 1997 to: (i) establish the Financial Sector Restructuring Authority (FRA), making it the temporary decision-maker on all matters related to financial sector restructuring; (ii) establish a state-owned AMC to deal with the assets of the finance companies and other distressed financial institutions; (iii) grant authority to the BOT to require capital write-downs, capital increases or changes in management in troubled financial institutions; and (iv) empower FIDF to provide capital support to troubled institutions.

To contain the crisis, the government introduced a blanket guarantee protecting all depositors and creditors. In 1998, the government intervened in 12 additional finance companies. Eventually, the government also intervened in 7 (out of a total of 15) commercial banks, accounting for one-quarter of financial sector assets. The government announced additional comprehensive measures in mid-1998, including a commitment to use public funds for recapitalization of viable financial institutions, equitable loss allocation and burden sharing arrangements, operational restructuring of the intervened banks, and their preparation for eventual privatization. To enhance private sector participation, foreign ownership rules for Thailand financial institutions were temporarily relaxed. (Of the seven intervened commercial banks, 5 were merged and 2 were sold to foreign investors.) In parallel, the government established the Corporate Debt Restructuring Advisory Committee in June 1998 to provide guidance to borrowers and creditors on out-of-court renegotiation and restructuring of troubled corporate debt. The TAMC was established in 2001 and granted special legal and administrative powers to flexibly manage, restructure and resolve distressed assets. TAMC was to purchase assets at their "fair value," with a pre-determined gain/loss sharing schemes between TAMC and banks. While private banks could sell only those NPLs that had multiple creditors and were in excess of B 5 million to TAMC, state banks were authorized to sell all of their NPLs to TAMC.

The magnitude of the task was enormous. The 56 intervened finance companies were transferred to the FRA. A total of B 1.4 billion of NPLs were transferred to state-owned AMCs, of which the intervened banks accounted for about 70 percent. Of the total transferred, state-owned AMCs managed B 854 billion in NPLs as of end-2006 and held foreclosed assets of B 114 million. The cash recovery rate has been approximately 15 percent. 


\section{APPENDIX II: STRESS TESTS}

168. The stress tests and scenario analysis undertaken in the context of the Thailand FSAP were designed jointly by both the BOT and the mission. The objective was to assess the resilience of the Thailand banking system to a variety of severe but plausible shocks. The tests were based on information for the eight largest Thailand commercial banks, which accounted for 88 percent of banking assets at end-2006. The tests built on banks' internal models and were complemented by the top-down models developed by the BOT and the FSAP team. The exercises comprised single-factor shocks and macroeconomic scenario analysis.

\section{Single factor shocks}

169. The sensitivity analysis covered market risk, interest risk and liquidity risk. Credit risk was dealt with in the context of the scenario analysis. The calibration of shocks was based on historical information (i.e., at least an entire economic cycle but also using judgment that calibrated parameters reflected plausible realizations).

170. Market risk stress tests included shocks to interest rates, exchange rates, and equity prices (Table 17). The size of the shocks was calibrated based on the 99 percentile of the historical distribution using a 10-day holding period (reflecting the average holding period of securities in banks' trading book):

- $\quad$ Shocks to interest rates (both shifts and tilts of the yield curve): THB, USD, JPY, EUR, GBP, SGD, and HKD;

- $\quad$ An increase/decrease in the bilateral exchange rate of the THB with respect to the USD, JPY, EUR, GBP, SGD, HKD, MYR;

- $\quad$ A decline in the SET equity index; and

- In addition to the single-factor shocks, banks were asked to report the results of a shift up in the yield curve (tilt with flattening case) combined with a fall in equity prices.

171. The stress tests for interest risk on the overall structural asset-liability position of banks included both parallel shifts, flattening, and tilts of the THB yield curve (as well as the yield curve of other relevant currencies, see Table 18). The shocks were calibrated based on the ninety-ninth percentile of the historical distribution of the relevant risk factor using a one-year holding period. A one-year window was used, as it represented the average holding period of the assets and liabilities in the banking book.

172. The BOT, in coordination with the mission, designed two liquidity shock scenarios, which were based on a survey of commercial banks' liquidity practices (Table 19). Most Thailand banks, in particular the larger and more established ones, rely 
Table 17. Thailand: Market Risk Stress Tests ${ }^{1}$

\begin{tabular}{|c|c|c|c|c|}
\hline \multirow[t]{2}{*}{ Interest Rate Risk: } & \multicolumn{3}{|c|}{$\begin{array}{c}\text { Size of Shocks } \\
\text { (In basis points) }\end{array}$} & \multirow{2}{*}{$\begin{array}{c}\text { Impact on CAR } \\
\text { (in percent) } \\
\text { Average }\end{array}$} \\
\hline & $<3$ month & $3-12 \mathrm{mc}$ & $>12$ month & \\
\hline \multirow[t]{6}{*}{ THB yield curve } & +75 & +75 & +75 & -0.04 \\
\hline & -50 & -50 & -50 & 0.03 \\
\hline & +50 & +75 & +100 & -0.05 \\
\hline & -50 & -75 & -100 & 0.05 \\
\hline & +100 & +75 & +50 & -0.04 \\
\hline & -100 & -75 & -50 & 0.04 \\
\hline \multicolumn{5}{|l|}{ USD yield curve } \\
\hline & +50 & +50 & +50 & 0.02 \\
\hline & -50 & -50 & -50 & -0.02 \\
\hline
\end{tabular}

Equity prices:

(In percent)

SET

Decline

20

0.00

Exchange rates:

USD Depreciation

9

0.00

Appreciation

10

0.00

Combination of shocks:

(In basis points)

Shock to THB yield

curve and $20 \%$ fall

equity price

$+100$

$+75$

$+50$

$-0.04$

Combination of

largest impacts

$-0.12$

Source: BOT and IMF staff.

${ }^{1}$ The interest rate stress tests also included shocks to other currencies' yield curves EUR, GBP, HKD, SGD and JPY. In addition to these currencies, the single-factor shocks to the exchange rates also included the MYR. The impact of all these shocks was negligible. 
Table 18. Thailand: Stress Tests for Interest Rate Risk on the Banking Book

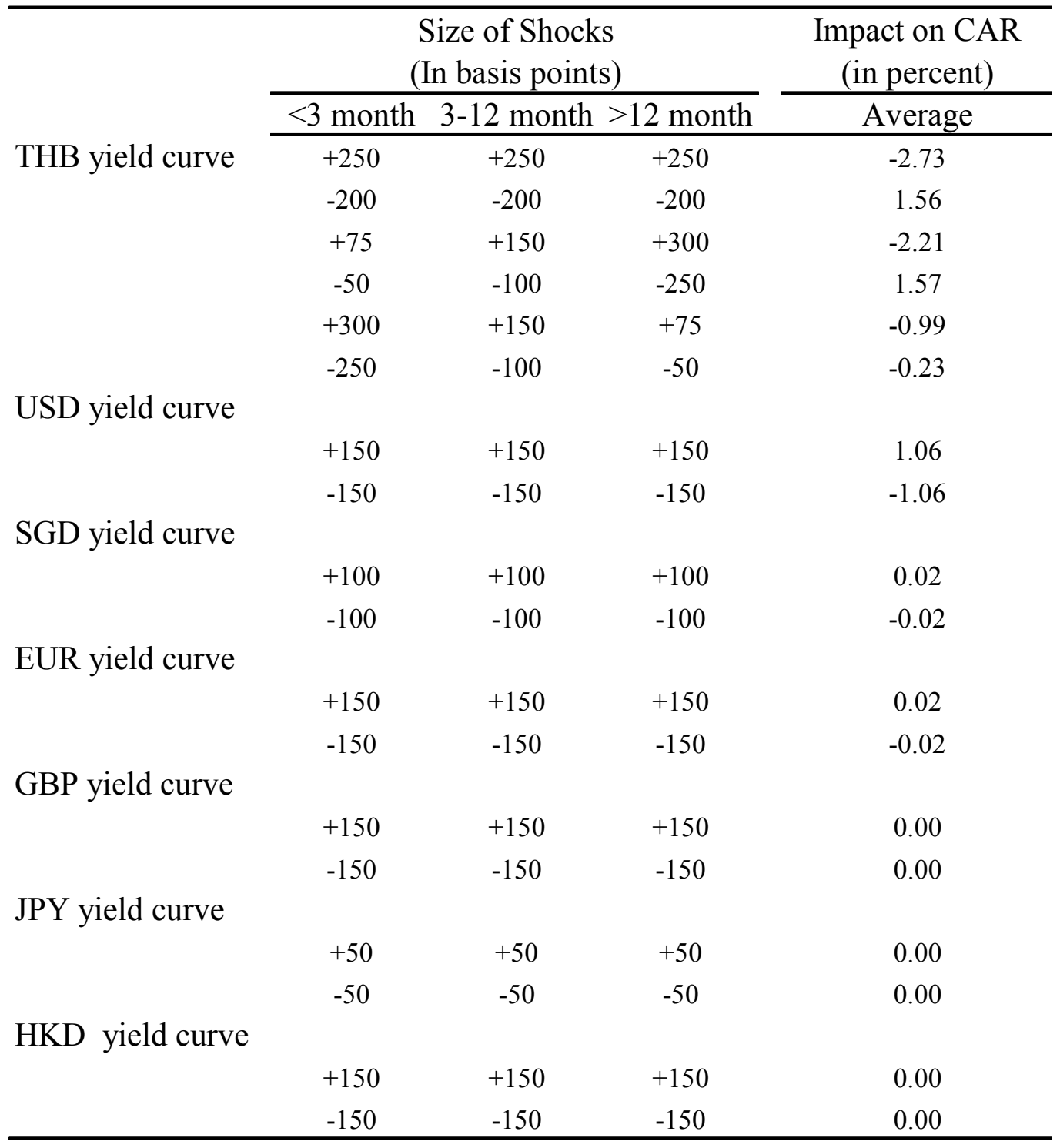

Sources: BOT and IMF staff. 


\section{Table 19. Thailand: Liquidity Stress Tests}

\section{Scenario 1}

Retail (1-7 days)

Retail (8 days - 1 month)

Wholesale
Deposit loss (percent)

10

15

30

Scenario 2 (in addition to deposit loss)

Access to interbank market limited to $50 \%$ of committed lines;

no access to uncommitted lines; and haircuts were applied

to the following assets:

T-bill

Govt. \& BoT

SoE (MoF)

SoE (non MoF)

Corporate Debt (listed)

Corporate Debt (non listed)

Stock (SET 50)

Other Instruments

Asset haircuts (percent)

3

5

7

15

20

40

20

100

Net liquidity position / deposits (percent)

Scenario 1 Results

Average

15.9

Scenario 2 Results

Average

3.3

Sources: BOT and IMF staff. 
mainly on local deposits for funding their operations. In the first scenario, we assumed a loss of 25 percent of the retail deposits and 30 percent of wholesale deposits. In a second, more severe scenario, the deposit outflow shock assumed under the first scenario was combined with an assumption of limited access to specific financing channels and haircuts on less liquid assets to simulate possible losses that a bank may face in the event of an unexpected need to liquidate assets in order to meet deposit outflows. ${ }^{19}$

\section{The stress tests also analyzed contagion risk through banks' exposures in the} interbank market. The scenarios analyzed the failure of each one of the largest banks in order to assess its impact on the system. The main channel of contagion was the interbank exposures. Exposure to withdrawal of international credit lines was not considered given Thailand banks' low balance exposure to this risk.

\section{Macroeconomic scenarios}

174. Macroeconomic scenarios included an external and a domestic event (Table 20). The effect of the scenario assumptions on key macroeconomic and financial variables was computed based on BOT's macro-econometric model and coordinated with IMF staff's macro framework for Thailand. The first scenario assumed a recession in the U.S. resulting in a sharp fall in the demand for Thailand exports. The scenario was calibrated to have overall a similar impact to sharp decline in U.S growth in $2001 .{ }^{20}$ Under this scenario, Thailand's real GDP growth was projected to fall to 2 percent in 2007 (significantly below the economy's estimated growth potential of 5 $\frac{1}{2}$ percent), recover gradually to 3 percent in 2008 and then to 5 percent in 2009. Simulations using BOT's macro model indicated that such severity levels would correspond to an event around the ninety-fifth percentile of the distribution of real GDP.

\section{The second macroeconomic scenario incorporated the domestic risk of policy} and political uncertainties having a major impact on domestic demand and foreign investors' confidence. A decrease in both domestic investment and domestic consumption would lead to a fall in real GDP growth across all sectors. However, as the Thailand economy has

\footnotetext{
${ }^{19}$ The liquidity stress scenarios — consisting of deposit outflows and asset haircuts—-were calibrated based on historical data and a survey on liquidity stress testing conducted by the BOT among Thailand commercial banks in preparation for the FSAP (Table 19 describes the two liquidity scenarios, including deposit outflows and asset haircuts by type of asset.)

${ }^{20}$ In 2001, as a result of the bursting of the global IT bubble and September 11, U.S. GDP growth fell by 3 percentage points, knocking nearly 16 percentage points from the growth of its import demand for goods and services. Because the slowdown in U.S. import demand was biased against electronic products, Asian economies were negatively affected, especially Thailand where GDP growth fell from 4.8 percent in 2000 to 2.2 percent in 2001 .
} 
Table 20. Thailand: Macro Scenarios

(In percent)

\begin{tabular}{|c|c|c|c|c|}
\hline & \multicolumn{2}{|c|}{ Scenario 1} & \multicolumn{2}{|c|}{ Scenario 2} \\
\hline & 2007 & 2008 & 2007 & 2008 \\
\hline GDP & 2.0 & 3.0 & 2.0 & 4.0 \\
\hline Domestic demand & 2.4 & 3.8 & -1.1 & 3.8 \\
\hline Private consumption & 1.2 & 2.2 & 0.2 & 2.0 \\
\hline Private investment & 0.1 & 0.8 & -2.0 & 1.4 \\
\hline Government consumption & 0.5 & 0.3 & 0.5 & 0.3 \\
\hline Public investment & 0.7 & 0.4 & 0.3 & 0.2 \\
\hline Net Exports & -0.4 & -0.7 & 3.2 & 0.2 \\
\hline Exports & 1.0 & 0.6 & 3.1 & 3.8 \\
\hline Imports & 1.4 & 1.4 & -0.1 & 3.6 \\
\hline Exchange rate (eop): THB/USD & 33.4 & 33.1 & 35.2 & 35.1 \\
\hline Headline inflation & 1.8 & 1.2 & 1.6 & 1.3 \\
\hline Core inflation & 1.2 & 1.1 & 1.2 & 1.3 \\
\hline Crude oil price (Dubai): USD/Barrel & 56.5 & 56.0 & 56.5 & 56.0 \\
\hline Real estate prices & -2.0 & 0.7 & -2.0 & 0.7 \\
\hline MLR & 7.4 & 6.4 & 7.4 & 6.4 \\
\hline Repo rate (1 day) & 2.8 & 1.8 & 2.8 & 1.8 \\
\hline
\end{tabular}

demonstrated fast recovery after historical episodes of "loss of confidence," it is assumed that the recovery will be comparatively faster than in the first scenario. ${ }^{21}$

\section{Bottom up approach ${ }^{22}$}

176. The models used by the eight banks generally relied on a bottom up approacha combination of their internal ratings, financial ratios and expert judgment - to translate the macroeconomic scenarios into the relevant risk factors for their portfolios (Table 21).

177. Four banks linked macroeconomics variables to the borrowers' financial ratios using their own internal rating models for the rated corporate portfolio. The banks were able to estimate the impact of the macroeconomic scenarios on the financial ratios and to re-classify

\footnotetext{
${ }^{21}$ To avoid overstraining commercial banks, given their limited capabilities to conduct stress testing, this scenario was only implemented using the top-down models in cooperation with the BOT.

${ }^{22}$ The bottom up and top down scenario results are shown in Table 21.
} 
Table 21. Thailand: Summary of Macro Scenario Stress Tests (In percent)

\begin{tabular}{|c|c|c|c|c|}
\hline & \multicolumn{2}{|c|}{ NPL } & \multicolumn{2}{|c|}{ CAR } \\
\hline & \multirow{2}{*}{$\begin{array}{c}\text { Average } \\
2006\end{array}$} & \multirow{2}{*}{$\begin{array}{c}2008 \\
\text { Average }\end{array}$} & \multirow{2}{*}{$\begin{array}{c}\text { Average } \\
2006\end{array}$} & \multirow{2}{*}{$\begin{array}{c}2008 \\
\text { Average }\end{array}$} \\
\hline & & & & \\
\hline \multicolumn{5}{|c|}{ Projections (assuming zero operating profits) } \\
\hline Bottom up: Scenario 1 & 8.3 & 15.3 & 12.7 & 8.8 \\
\hline Top down: Scenario 1 & 8.3 & 17.6 & 12.7 & 7.6 \\
\hline Top down: Scenario 2 & 8.3 & 17.0 & 12.7 & 7.9 \\
\hline \multicolumn{5}{|c|}{ Projections (assuming nonzero operating profits) } \\
\hline Bottom up: Scenario 1 & 8.3 & 15.3 & 12.7 & 11.4 \\
\hline Top down: Scenario 1 & 8.3 & 17.6 & 12.7 & 10.2 \\
\hline Top down: Scenario 2 & 8.3 & 17.0 & 12.7 & 10.5 \\
\hline
\end{tabular}

Sources: Commercial banks, BOT, and IMF staff.

the borrowers accordingly. Provisions were then calculated based on the migrated rating. With regard to banks' unrated corporate and retail credit portfolios, methods varied widely. Some banks used a new benchmark probability of default (PDs) directly based on the highest NPL ratio over the past seven years. Others applied an econometric-based approach using a macro model by sector and by product type.

178. Two banks used financial ratios and expert judgment to re-classify loans as performing or nonperforming based on some qualitative and quantitative methods. In one bank, the qualitative factors were largely based on expert judgment and internal loan review guidelines. In another bank, the methodology was based on key financial ratios and corresponding critical thresholds.

179. The remaining two banks used an approach very similar to the top down macroeconometric model developed by the BOT and the mission (see below). While one of the banks relied on a single equation model, another institution used several econometric models fitted to specific portfolios by sector and by type of counterparty.

\section{Top down approach}

180. The BOT and the mission estimated an econometric model that related the PDs to the key macro-financial variables from the macro scenario. The econometric model (a dynamic panel data approach) was then used to estimate the stressed PDs and the impact on provisions and capital. Given the unavailability of historical information on default rates, the econometric analysis used bank-level NPLs as proxies for default rates. The historical 
NPL data had to be adjusted to account, for instance, for previous NPL transfers to asset management companies in order to reduce the noise in the time series. The stressed PDs, together with the downturn loss-given-defaults and the exposures (information provided by the banks), were combined using an efficient algorithm (Credit Risk + ) to compute the portfolio-loss distribution for each bank. This in turn was used to compute expected and unexpected losses and to evaluate tail risks. 


\section{StatistiCAL APPENDix}

Table 22. Thailand: Core and Encouraged Set of Financial Soundness Indicators

\begin{tabular}{|c|c|c|c|c|c|c|}
\hline & 2002 & 2003 & 2004 & 2005 & 2006 & 2007 \\
\hline \multicolumn{7}{|l|}{ Capital adequacy } \\
\hline Regulatory capital as percent of risk-weighted assets* & 13.6 & 14.0 & 13.0 & 13.9 & 14.1 & 15.0 \\
\hline Regulatory Tier I capital to risk weighted assets* & 10.0 & 10.5 & 10.0 & 11.0 & 11.6 & 12.4 \\
\hline of which Hybrid Tier I capital to risk-weighted assets & 2.2 & 1.7 & 0.4 & 0.1 & 0.3 & 0.3 \\
\hline Capital as percent of assets* & 8.1 & 8.9 & 8.7 & 10.0 & 9.9 & 10.5 \\
\hline \multicolumn{7}{|l|}{ Asset composition } \\
\hline Bank domestic credit & $4,603.5$ & $4,727.8$ & $5,116.1$ & $5,551.4$ & $5,738.4$ & $6,038.3$ \\
\hline Corporate credit & $4,037.8$ & $4,069.6$ & $4,328.4$ & $4,561.6$ & $4,556.9$ & $4,628.4$ \\
\hline Consumer loans & 565.7 & 658.2 & 787.8 & 989.8 & $1,181.5$ & $1,409.9$ \\
\hline \multicolumn{7}{|l|}{ Sectoral distribution of bank corporate credit (as percent of total loan exposure) * } \\
\hline Real estate & 5.5 & 5.0 & 5.4 & 5.4 & 5.5 & 5.7 \\
\hline Construction & 3.1 & 2.9 & 3.1 & 3.0 & 3.1 & 2.8 \\
\hline Manufacturing & 26.1 & 25.5 & 27.4 & 26.5 & 26.3 & 25.2 \\
\hline Commercial & 19.1 & 17.8 & 17.4 & 16.6 & 16.6 & 16.3 \\
\hline Public Utilities & 5.8 & 5.0 & 6.3 & 6.5 & 6.0 & 5.9 \\
\hline Services & 6.6 & 6.9 & 7.9 & 8.0 & 7.7 & 7.0 \\
\hline Banking and Financial Business & 18.6 & 15.6 & 12.8 & 12.5 & 11.1 & 11.4 \\
\hline Other & 2.9 & 7.5 & 4.4 & 3.7 & 3.2 & 2.3 \\
\hline \multicolumn{7}{|l|}{ Asset quality } \\
\hline Non-performing loans (NPL) as percent of gross loans $*$ & 15.7 & 12.9 & 10.9 & 8.3 & 7.5 & 7.3 \\
\hline Foreclosed assets as percent of total assets & 2.3 & 2.1 & 2.3 & 2.3 & 2.0 & 1.8 \\
\hline Provisions + write-offs as percent of NPL & 66.1 & 78.3 & 77.7 & 77.7 & 77.1 & 81.4 \\
\hline NPL net of provisions as percent of tier I capital * & 69.3 & 38.7 & 38.6 & 25.7 & 19.0 & 16.6 \\
\hline Large exposures as percent of tier I capital $*$ & 288.8 & 220.4 & 176.4 & 131.6 & 103.5 & 101.9 \\
\hline Exposure to 10 largest names & 1,106 & 996 & 859 & 832 & 733 & 800 \\
\hline Loan loss provision to NPL " "." & 64.3 & 71.8 & 67.0 & 65.5 & 69.5 & 71.2 \\
\hline Loan loss provision to gross loans & 10.1 & 9.2 & 7.3 & 5.4 & 5.2 & 5.2 \\
\hline \multicolumn{7}{|l|}{ Earnings and profitability } \\
\hline Net profits as percent of average assets (ROAA) $*$ & 0.3 & 0.7 & 1.3 & 1.4 & 0.8 & 0.3 \\
\hline Net profits as percent of average equity capital (ROAE) * & 3.4 & 7.8 & 13.3 & 12.1 & 7.1 & 2.7 \\
\hline Net interest margin (net interest income as percent of average assets) * & 1.8 & 2.0 & 2.5 & 2.8 & 3.1 & 3.1 \\
\hline Gross income as percent of average assets & 3.2 & 3.2 & 3.8 & 4.0 & 4.3 & 4.3 \\
\hline Net interest income as percent of gross income & 57.7 & 62.9 & 64.3 & 68.5 & 71.5 & 72.7 \\
\hline Non-interest income as percent of gross income & 42.3 & 37.1 & 35.7 & 31.5 & 28.5 & 27.3 \\
\hline Trading and foreign exchange income as a percent of gross income * & 9.5 & 13.8 & 10.7 & 5.2 & 7.5 & 5.0 \\
\hline Non-interest expenses as percent of gross income * & 68.6 & 58.3 & 55.5 & 55.1 & 56.9 & 59.3 \\
\hline Expense for provision to net financial margin & 30.2 & 22.7 & 11.2 & 8.8 & 24.3 & 34.4 \\
\hline Non-interest expenses as percent of average assets* & 2.2 & 1.9 & 2.1 & 2.2 & 2.4 & 2.6 \\
\hline Staff costs as percent of non-interest expenses * & 28.3 & 33.8 & 32.5 & 32.0 & 31.3 & 31.5 \\
\hline Spread between reference loan and deposit rates $*$ & 6.1 & 6.0 & 5.8 & 4.8 & 4.3 & 5.3 \\
\hline Spread between highest and lowest domestic interbank rate* & 4.3 & 0.8 & 0.9 & 1.9 & 0.8 & 0.9 \\
\hline Number of employees & 86,980 & 87,671 & 90,537 & 99,786 & 105,804 & 111,128 \\
\hline Number of branches & 3,650 & 3,730 & 3,893 & 4,230 & 4,711 & 5,054 \\
\hline \multicolumn{7}{|l|}{ Liquidity } \\
\hline Liquid assets as percent of total assets $*$ & 28.6 & 23.6 & 18.6 & 16.4 & 18.4 & 20.3 \\
\hline Liquid assets as percent of short-term liabilities * & 41.3 & 30.0 & 23.8 & 21.1 & 22.9 & 25.3 \\
\hline Foreign currency loans as percent of total loans * & 9.2 & 8.6 & 9.3 & 7.7 & 6.7 & 6.4 \\
\hline Foreign currency liabilities as percent of total liabilities * & 4.4 & 4.4 & 4.2 & 4.5 & 4.1 & 3.9 \\
\hline Deposits as percent of assets & 81.8 & 80.8 & 79.1 & 78.2 & 76.5 & 73.7 \\
\hline Loans as percent of deposits * & 89.4 & 87.3 & 90.8 & 91.0 & 89.0 & 93.9 \\
\hline FX loans-to-FX deposits & 282.6 & 304.0 & 323.2 & 237.7 & 194.3 & 202.3 \\
\hline FX loans and held-to-maturity investments-to-FX deposits & 326.3 & 355.6 & 348.5 & 273.3 & 221.6 & 235.3 \\
\hline \multicolumn{7}{|l|}{ Sensitivity to market risk } \\
\hline Off-balance sheet and derivative as percent of assets & 84.8 & 85.3 & 93.8 & 132.0 & 151.9 & 187.8 \\
\hline of which foreign exchange operations & 50.0 & 45.5 & 47.0 & 59.3 & 65.6 & 80.4 \\
\hline of which interest rate operations & 10.3 & 16.4 & 24.4 & 48.1 & 59.7 & 78.0 \\
\hline of which: credit default swaps and similar & n.a. & n.a. & 0.1 & 0.1 & 0.2 & 0.2 \\
\hline other & 24.5 & 23.4 & 22.2 & 24.5 & 26.4 & 29.2 \\
\hline Gross asset position in derivatives as a percentage of tier I capital $*$ & n.a. & n.a. & n.a. & n.a. & n.a. & n.a. \\
\hline Gross liability position in derivatives as a percentage of tier I capital * & n.a. & n.a. & n.a. & n.a. & n.a. & n.a. \\
\hline Gross positions in derivative in trading book & n.a. & n.a. & $4,791.4$ & $6,936.8$ & $10,587.2$ & $14,730.3$ \\
\hline Gross positions in derivative in banking book & n.a. & n.a. & 584.1 & 686.1 & 924.8 & 913.9 \\
\hline Duration of assets & n.a. & 0.8 & 0.8 & 0.8 & 0.8 & 0.8 \\
\hline of which loans & n.a. & 0.8 & 0.7 & 0.7 & 0.7 & 0.6 \\
\hline of which treasury bills, government bonds and BOT bonds. & n.a. & n.a. & 1.9 & 1.8 & 1.9 & 1.8 \\
\hline Duration of liabilities & n.a. & 0.3 & 0.3 & 0.3 & 0.3 & 0.2 \\
\hline Holdings of real estate and other fixed assets & 128.4 & 130.0 & 130.2 & 143.6 & 148.3 & 149.5 \\
\hline Aggregate net position in foreign exchange as a percentage of tier I capital & -4.7 & -3.1 & -2.8 & -1.4 & -0.2 & -2.9 \\
\hline
\end{tabular}

Source: Data provided by Thai authorities

* Core and encouraged set of indicators. 
Figure 7. Thailand: Regional Comparison of Structure of Financial Sector
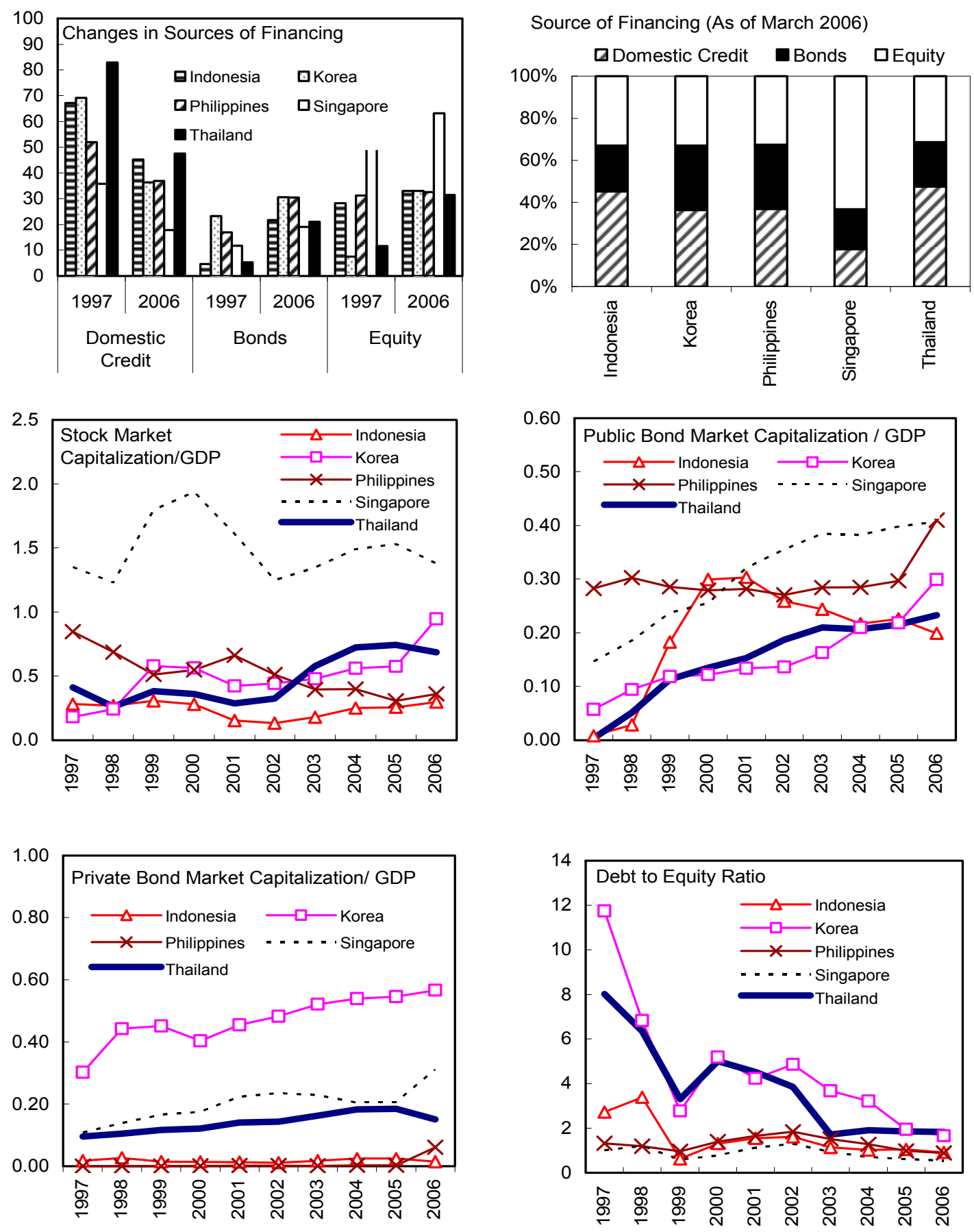

Sources: World Bank; Asian Bondsonline- Asia Bond Indicators. Note: 2006 data indicates March 2006 data. 
Table 23. Thailand: Regional Bond Market Indicators, End-2006

\begin{tabular}{lrrrrrrrrr}
\hline & \multicolumn{2}{c}{ as a Percentage of GDP } & \multicolumn{2}{c}{ in USD billions } & \multicolumn{3}{c}{ Turnover ratio } \\
& Govt & \multicolumn{1}{c}{ Corp } & \multicolumn{1}{c}{ Total } & Govt & Corp & Total & Govt & Corp & Total \\
\hline Thailand* & 38 & 19 & 58 & 75 & 37 & 112 & 1.6 & 0.1 & 1.1 \\
China & 31 & 16 & 46 & 786 & 398 & 1,184 & 1.4 & 0.8 & 1.2 \\
Hong Kong & 9 & 42 & 51 & 17 & 79 & 96 & 68.2 & 0.2 & 12.1 \\
Indonesia & 13 & 2 & 15 & 47 & 7 & 53 & 0.8 & 0.3 & 0.8 \\
Korea** & 54 & 56 & 109 & 469 & 490 & 959 & 2.6 & 0.5 & 1.6 \\
Malaysia & 41 & 41 & 83 & 61 & 60 & 121 & 1.9 & 0.6 & 1.3 \\
Philippines & 37 & & 37 & 44 & & 44 & & & \\
Singapore & 42 & 32 & 74 & 56 & 43 & 99 & 2.5 & - & 1.4 \\
Vietnam & 8 & 1 & 9 & 5 & 0 & 5 & & & \\
\hline
\end{tabular}

Source: Asian Bonds Online

*The total for corporate debt securities also includes bonds issued by state owned enterprises.

**Data on turnover ratio is for Dec-2005. 